EL DERECHO A LA VERDAD COMO JUSTIFICACIÓN DE AMNISTÍAS E INDULTOS A VICTIMARIOS

ALBERTO POVEDA RODRÍGUEZ

UNIVERSIDAD SANTO TOMÁS

FACULTAD DE DERECHO

MAESTRÍA EN DERECHO PÚBLICO

BOGOTÁ, D.C.

2018 


\title{
EL DERECHO A LA VERDAD COMO JUSTIFICACIÓN DE AMNISTÍAS E INDULTOS A VICTIMARIOS
}

\author{
ALBERTO POVEDA RODRÍGUEZ ${ }^{1}$ \\ ESTUDIANTE
}

TESIS DE MAESTRÍA

CORINA DUQUE AYALA

DIRECTORA DE TESIS

UNIVERSIDAD SANTO TOMÁS

FACULTAD DE DERECHO

MAESTRÍA EN DERECHO PÚBLICO

BOGOTÁ, D.C.

2018

\footnotetext{
${ }^{1}$ Abogado de la Universidad Católica de Colombia y Especialista en Derecho Administrativo de la Universidad Santo Tomás de Colombia.
} 


\section{AGRADECIMIENTOS}

Agradezco a mi padre, Alberto Poveda Perdomo, quien ha sido mi guía y ejemplo profesional, un intelectual y hábil académico que, al igual que mi madre, Martha Rodríguez, me han enseñado que en la vida todo se consigue con trabajo, dedicación y honestidad.

Quiero, también, tener un reconocimiento con una brillante maestra, persistente e impecable profesional, quien ha sido una guía fundamental para la elaboración de esta tesis y mi desarrollo como investigador, la Dra. Corina Duque Ayala. 
CONTENIDO

TÍTULO: EL DERECHO A LA VERDAD COMO JUSTIFICACIÓN DE AMNISTÍAS E INDULTOS A VICTIMARIOS

INTRODUCCIÓN

CAPÍTULO INTRODUCTORIO

MARCO DE REFERENCIA EN MATERIA DE JUSTICIA Y VERDAD: ACUERDO FINAL PARA LA PAZ EN COLOMBIA

1. BREVE RESEÑA SOBRE EL CONFLICTO ARMADO COLOMBIANO: 1930-2012

2. LA SUSCRIPCIÓN DEL ACUERDO FINAL PARA LA PAZ

3. ACUERDO FINAL PARA LA PAZ: LINEAMIENTOS SOBRE EL DERECHO A LA VERDAD, AMNISTÍAS E INDULTOS

PRIMERA PARTE

EL DERECHO A LA VERDAD DE LAS VÍCTIMAS Y LAS INSTITUCIONES AMNISTÍA E INDULTO PARA UN PROCESO DE RECONCILIACIÓN NACIONAL CAPÍTULO PRIMERO

EL DERECHO A LA VERDAD DE LAS VÍCTIMAS DEL CONFLICTO ARMADO: ESPECIAL REFERENCIA AL CASO COLOMBIANO

1. EL DERECHO A LA VERDAD Y LAS VÍCTIMAS

1.1. Algunos acercamientos a la definición de los derechos fundamentales

1.2. Teorías sobre la verdad 
1.3. Derecho a la verdad de las víctimas y su aplicabilidad en Colombia

2. EL DERECHO A LA VERDAD EN EL ACUERDO FINAL PARA LA PAZ: MECANISMO DE PROTECCIÓN Y GARANTÍAS DEL DERECHO A LA VERDAD EN LA IMPLEMENTACIÓN

2.1. Mecanismo de garantía del derecho a la verdad en el Acuerdo Final

2.2. Garantías del derecho a la verdad de las víctimas en la implementación del Acuerdo final

\section{CAPÍTULO SEGUNDO}

\section{LA AMNISTÍA Y EL INDULTO: ALIVIOS PENALES DEL ACUERDO DE PAZ}

1. BREVE RESEÑA HISTORICA SOBRE LA AMNISTÍA Y EL INDULTO

2. LA AMNISTÍA Y EL INDULTO EN COLOMBIA

3. AMNISTÍA E INDULTO: CONCEPTO, CARACTERÍSTICAS, DIFERENCIAS Y SIMILITUDES

3.1. Intentos de la doctrina por definir las instituciones amnistía e indulto

3.2. Características semejanzas y diferencias entre la amnistía y el indulto

4. PERSPECTIVA NORMATIVA Y JURISPRUDENCIAL SOBRE LA AMNISTÍA Y EL INDULTO: ESPECIAL REFERENCIA AL CASO COLOMBIANO

4.1. Constitución, leyes y decretos

4.2. Hermenéutica jurisprudencial sobre la amnistía y el indulto

5. LA AMNISTÍA Y EL INDULTO EN EL MARCO DEL ACUERDO FINAL Y DESARROLLO DESDE LA PERSPECTIVA JURISPRUDENCIAL

5.1. Tratamientos sobre la amnistía y el indulto en el Acuerdo final 
5.2. Explicación y desarrollo normativo de la ley de amnistía e indulto desde la perspectiva jurisprudencial

\section{SEGUNDA PARTE}

PROCESO DE JUSTICIA TRANSICIONAL: JUSTIFICACIÓN DE LAS AMNISTÍAS Y LOS INDULTOS PARA GARANTÍZAR LA VERDAD DE LAS VÍCTIMAS Y UNA PAZ ESTABLE Y DURADERA

\section{CAPÍTULO TERCERO}

\section{JUSTICIA TRANSICIONAL PARA LA CONSTRUCCIÓN DE UNA PAZ ESTABLE Y DURADERA}

1. ACERCAMIENTO AL CONCEPTO DE JUSTICIA Y SUS CLASES

2. APROXIMACIONES AL CONCEPTO DE JUSTICIA TRANSICIONAL

3. JUSTICIA TRANSICIONAL EN ALEMANIA Y BRASIL: LAS EXPERIENCIAS DE OTROS PAISES

3.1. Justicia transicional en Alemania

3.2. Justicia transicional en Brasil

4. JUSTICIA TRANSICIONAL EN COLOMBIA Y FINES DE LAS SANCIONES A IMPONER

4.1. Desarrollo del concepto de justicia transicional en Colombia

4.2. Fines de las sanciones o penas en la justicia transicional

5. DE LA RESPONSABILIDAD Y LAS SANCIONES EN LA JURISDICCIÓN ESPECIAL PARA LA PAZ 
5.1. Responsables ante la Jurisdicción Especial para la Paz

5.2. Sanciones en la Jurisdicción Especial para la Paz: Sanciones significativas, alternativas y sustitutivas

5.3. Descripción de las sanciones significativas, alternativas y sustitutivas

5.4. Descripción de las sanciones previstas en el Acuerdo Final para la Paz

5.5. Fines y funciones de las sanciones previstas en el Acuerdo Final para la Paz

\section{CAPÍTULO CUARTO}

DERECHO A LA VERDAD COMO JUSTIFICACIÓN DE AMNISTÍAS E INDULTOS ¿IMPUNIDAD O JUSTICIA?

1. LA JUSTICIA TRANSICIONAL APLICABLE AL CASO COLOMBIANO COMO LA MEDIDA DE JUSTA PROPORCIÓN PARA LOGRAR LOS FINES DEL ESTADO

1.1. Precisión inicial sobre el indulto

1.2. Precisiones sobre la impunidad en el caso concreto

1.3. El derecho a la verdad como justificación de amnistías e indultos: razones que las hacen justas y desvirtúan cualquier asomo de impunidad

1.4. Garantía del derecho a la verdad como condición para las sanciones alternativas, propias y ordinarias

1.5. En busca de la proporcionalidad en la concesión de amnistías e indultos

1.6. Nociones de la justicia aplicadas en el proceso de justicia transicional colombiano

CONCLUSIONES

REFERENCIAS BIBLIOGRÁFICA 


\section{EL DERECHO A LA VERDAD COMO JUSTIFICACIÓN DE AMNISTÍAS E INDULTOS A VICTIMARIOS}

\section{INTRODUCCIÓN}

El proyecto desarrolla el derecho fundamental de las víctimas a la verdad, hasta el punto de tomarlo como fundamento del decreto de amnistías e indultos para los autores del conflicto, argumentando cómo dichas prerrogativas no constituyen un acto de impunidad en el marco de la justicia transicional en Colombia.

Lo anterior, basado en que Colombia es un país que ha permanecido en conflicto armado desde los años sesenta del siglo XX, década a la que se remonta la aparición de grupos insurgentes que se han opuesto por medio de las armas a la institucionalidad vigente. Fue en el 2016 que se pudo llegar a un Acuerdo de Paz con el grupo guerrillero con mayor presencia en el territorio nacional, que tenía en filas a cerca de diez mil hombres con una definida estructura piramidal, las Fuerzas Armadas Revolucionarias de Colombia, Ejército del Pueblo (en adelante FARC-EP).

Si bien el texto original del Acuerdo de Paz (Gobierno Nacional-FARC-EP, 2016) no fue aprobado en el plebiscito convocado el 2 de octubre para el efecto, el Gobierno Nacional y los sectores opositores procuraron dirimir discrepancias en torno a su contenido y, así, llegar a un nuevo acuerdo. La Mesa de Negociaciones de La Habana tuvo la tarea de pactar en términos que evitaran la crispación política, para dar la resolutiva de un nuevo acuerdo aprobado el 12 de noviembre de 2016, que fue sometido a un proceso de aprobación o refrendación por el Congreso de la República, que permitió su vigencia y entrada en vigor. 
El Acuerdo Final para la Terminación del Conflicto y la Construcción de una Paz Estable y Duradera (2016), suscrito por representantes del Gobierno Nacional y de las FARC-EP, estableció originalmente, como centro del pacto entre las partes reseñadas, el punto 5, que trata sobre el resarcimiento a las víctimas directas del conflicto armado, disponiendo un Sistema Integral de Verdad, Justicia, Reparación y no Repetición, dentro del cual se incluyeron los componentes de Verdad y Justicia; el primero, que está en cabeza de la Comisión para el Esclarecimiento de la Verdad, la Convivencia y la No Repetición; y el segundo, a cargo de la Jurisdicción Especial para la Paz (en adelante JEP).

La Comisión para el Esclarecimiento de la Verdad, la Convivencia y la No Repetición tiene entre sus objetivos contribuir con el esclarecimiento de lo ocurrido y ofrecer una explicación de la complejidad del conflicto armado interno, con el fin de que la sociedad entienda los aspectos más desconocidos de este. Por otro lado, a la JEP se le asignó competencia para resolver los asuntos de los guerrilleros, agentes del estado y particulares que hayan cometido conductas delictivas relacionadas con el conflicto armado interno y, a través del formato de justicia que tendrá dicha corporación, podrá otorgarse un tratamiento diferente al ordinario (más benigno) a partir de la concesión de amnistías e indultos, condicionado al reconocimiento de la verdad (Gobierno Nacional-FARC-EP, 2016). Dependiendo de la mayor verdad aportada por quienes se sometan a la JEP, se les podrá imponer las diferentes clases de penas que previó el Acuerdo Final: propias, alternativas y ordinarias.

El marco de la justicia transicional está encaminado a satisfacer el derecho de las víctimas a la justicia, ofrecer verdad a la sociedad colombiana, contribuir al logro de una paz estable y duradera, y adoptar decisiones que otorguen plena seguridad jurídica a quienes participaron de manera directa o indirecta en el conflicto armado interno (Gobierno Nacional-FARC-EP, 2016). 
Así mismo, dado que un proceso de justicia transicional no puede ni necesita dar respuesta judicial a todos y cada uno de los hechos jurídicamente relevantes, se previó el otorgamiento de amnistías e indultos así como la asignación de facultades para ordenar la cesación de la acción penal, en aras de seleccionar los casos más relevantes y juzgar a los máximos responsables.

El equilibrio entre derechos de las víctimas y juzgamiento de los máximos responsables, según lo considerado por el Acuerdo, permite que las primeras vean satisfechos sus derechos y los segundos tengan la seguridad de ser sometidos una sola vez por la jurisdicción, sin que a futuro se abran nuevamente las causas criminales. En consecuencia, el pacto de paz alcanzado queda sellado de manera definitiva y se garantiza el deber jurídico del Estado colombiano de alcanzar la paz en el conflicto armado interno, como uno de los objetivos del componente de justicia (Gobierno Nacional-FARC-EP, 2016).

De lo expuesto, surge la siguiente pregunta: ¿constituye el derecho a la verdad un instrumento que justifica las amnistías e indultos establecidos en el Acuerdo Final para la Paz, sin que ello constituya impunidad? Este interrogante debe resolverse a partir del objetivo general de la investigación: determinar cómo el derecho a la verdad, en el marco de la justicia transicional, se erige como mecanismo de justificación de las amnistías e indultos que se ofrecen a los integrantes de las FARC-EP que contribuyan a la consolidación de una paz estable y duradera en Colombia.

Para tal fin, como objetivos específicos se tienen: (i) establecer el contenido y alcance del derecho a la verdad en el marco del Acuerdo Final suscrito entre el Gobierno y las FARC-EP; (ii) definir las instituciones amnistía e indulto desde la perspectiva constitucional y el Acuerdo 
Final de Paz; (iii) determinar cómo en Colombia las amnistías y los indultos pueden llegar a constituir instituciones idóneas, en el marco de la justicia transicional, para conseguir la reconciliación nacional y contribuir a la finalización del conflicto armado interno; y, por último, (iv) establecer cómo el derecho a la verdad de las víctimas del conflicto armado colombiano legitima las amnistías e indultos dispuestos para las FARC-EP sin que dichas prerrogativas generen impunidad.

En ese sentido, mediante el desarrollo de los objetivos planteados, la hipótesis de la presente investigación es: el hecho de que el Estado colombiano, con motivo de la finalización de las hostilidades, de acuerdo con el Derecho Internacional Humanitario, otorgue amnistías, indultos y otros tratamientos especiales a los actores del conflicto armado (beneficios que se extienden a los autores de crímenes de lesa humanidad y otros definidos en el Estatuto de Roma) que reconozcan la verdad como factor determinante para la concesión de dichas prerrogativas, no representa impunidad, porque esos alivios están enfocadas a la protección del derecho a la verdad, pues solo a través de la verdad aportada por los victimarios y con el reconocimiento de la misma es que pueden otorgarse los beneficios.

Es pertinente precisar que los actores del conflicto armado que son cobijados con dichas prerrogativas han sido autores de conductas delictivas, los cuales, en un marco de justicia ordinaria, no merecen un trato diferente. Es más, por su complejidad y tratándose de violaciones sistemáticas a derechos de los integrantes del Estado, tienen previstas las sanciones más fuertes y restrictivas; empero, por tratarse del juzgamiento en un marco de justicia transicional, en el que todo deviene de un periodo de conflicto interno, el objetivo principal es reparar a las víctimas y llegar a la paz, por lo que el reconocimiento de la verdad de los actores del conflicto armado 
hacia las víctimas, como medida de reparación y reconocimiento, constituye una reacción justa y proporcionada en el marco de las finalidades del Estado.

Con el único fin de que los máximos responsables de delitos atroces confiesen, se implementan medidas encaminadas a brindar los mecanismos necesarios para proteger los derechos de las víctimas. En ese sentido, el derecho a la verdad constituye un instrumento que justifica las amnistías e indultos, en la medida en que, a partir de la ratificación del derecho a la verdad como derecho fundamental de las víctimas del conflicto armado interno, se obliga a las instituciones jurídico políticas del Estado colombiano a velar por su protección, con el propósito de cesar la violación a derechos fundamentales; situación que justifica los privilegios otorgadas a los máximos responsables, como una medida política que busca restablecer a las víctimas y cesar el conflicto armado, garantizando una paz estable y duradera.

Así, se puede inferir, en principio, que las amnistías e indultos concedidos a los rebeldes son legítimos, al estar condicionados a la contribución de la verdad, y se descarta cualquier asomo de impunidad, pues, desde la percepción de justicia de este tratado, es válido garantizar el derecho a la verdad otorgando amnistías e indultos, en un marco de justicia donde, de la reciprocidad entre las partes que componen desigualdades sociales, surge una victoria común.

Ahora bien, para llegar a la hipótesis planteada el texto se desenvolverá en cuatro capítulos, que se concentran en dos partes: la primera, que se denomina: "el derecho a la verdad de las víctimas y las instituciones amnistía e indulto para un proceso de reconciliación nacional"; y, la segunda, que se titula: "proceso de justicia transicional: justificación de las amnistías y los indultos para garantizar la verdad de las víctimas y una paz estable y duradera". 
Finalmente, cabe resaltar que la presente investigación se desarrollará teniendo como respaldo la metodología axiomática o deductiva, de modo que para demostrar la hipótesis planteada se partirá de teorías, principios, normas y conocimientos generales sobre los temas que soportan el argumento principal, aplicando dichos elementos al marco en el que se circunscriben los objetivos específicos (Ponce de León Armenta, 1996, P. 73). 


\section{CAPÍTULO INTRODUCTORIO}

\section{MARCO DE REFERENCIA EN MATERIA DE JUSTICIA Y VERDAD: ACUERDO FINAL PARA LA PAZ EN COLOMBIA}

Uno de los marcos de referencia que tiene esta investigación se basa en el conflicto armado colombiano con las FARC-EP, el cual dejó víctimas y victimarios, y en el posconflicto que conlleva a dar garantías reales para la protección de los derechos de las víctimas y de los agentes que intervinieron en la guerra cometiendo diversos delitos. Por eso, además de ser necesario explicar un poco la historia de lo que sucedió, es igualmente importante conocer qué dice el Acuerdo Final para la Paz (2016) sobre el derecho a la verdad de las víctimas y las amnistías e indultos que se otorgan a los victimarios, de manera que, si entendemos de entrada la composición especial de estos puntos, se facilitará la comprensión de los capítulos posteriores.

\section{BREVE RESEÑA SOBRE EL CONFLICTO ARMADO COLOMBIANO: 1930-2012}

En el siglo XX, específicamente para 1930, como consecuencia de la violencia, con el ascenso del partido liberal a la Presidencia de la República de Colombia y por ende con la pérdida del poder que había estado en manos del partido conservador, vinieron días sangrientos para la Nación: fusilamientos en masa de personas indefensas, iglesias e imprentas fueron quemadas o destruidas de otras formas, y varios jefes conservadores fueron asesinados (Guzmán Campos, Fals Borda, \& Umaña Luna, 2010, págs. 39-40).

La hegemonía conservadora se inició con la institucionalización de un sistema político concentrado, en el que el Presidente de la República tenía poderes extradimensionados para enfrentar todo tipo de emergencias o conmociones: eliminó las libertades, otorgó amplias 
facultades a la iglesia católica y consolidó un régimen de desigualdades con un precario desarrollo económico (Melo, 2018, p. 167-196).

El panorama no cambia mucho para 1948, cuando ocurre el asesinato de Jorge Eliécer Gaitán, hecho reprochable de la violencia en Colombia, ya que se consideraba el líder que luchaba por las desigualdades sociales y le daba esperanza de paz al país (Montalvo Velásquez, 2012, p. 53). Para ese momento comenzaron a surgir los grupos revolucionarios armados al margen de la ley, constituidos por personas en desacuerdo con las políticas sociales: las Fuerzas Armadas Revolucionarias de Colombia (FARC-EP) en 1964, la Unión Camilista - Ejército de Liberación Nacional (UC-ELN) en 1965, el Ejército Popular de Liberación (EPL) en 1968 y el Movimiento 19 de Abril (M19) en 1970 (Giraldo Forero, 2005).

En el gobierno de Belisario Betancourt (1982-1986) se planteó una tregua y cese al fuego con el M19, el EPL y las FARC-EP, por lo que al sancionar la Ley 35 de 1982 se produjo la libertad de la mayoría de los presos de las guerrillas. Se trató de una amnistía general relacionada con los delitos políticos y conexos, con excepción de los crímenes atroces; sin embargo, dicho proceso se debilitó por la ausencia de resultados y las oposiciones de los diferentes sectores del Estado, lo cual conllevó a la ruptura de las treguas de cese al fuego por parte de las guerrillas del M19 y el EPL, las FARC-EP fueron los únicos que mantuvieron el cese al fuego. (Villarraga Sarmiento, 2015, págs. 9-34).

Para el gobierno de Virgilio Barco (1986-1990) se planteó, como política de paz, superar la pobreza y la exclusión social para acabar con las razones objetivas de la violencia y se promovió una estrategia sustentada en la reconciliación, rehabilitación y normalización nacional, bajo el título de "mano tendida y pulso firme", mediante la cual el gobierno mantuvo la vigencia 
de la tregua y las charlas con el grupo de las FARC-EP. Sin embargo, no se terminaban de asentar dichas políticas de paz cuando el paramilitarismo empezó a crecer con sus ataques contra la Unión Patriótica (UP) y contra diversos sectores de la oposición, como lo eran los movimientos sociales de izquierda. De la misma manera, el narcotráfico se potenció con atentados terroristas. Los auges de nuevas organizaciones delincuenciales deterioraron los diálogos con las FARC-EP hasta que, finalmente, se produjo la ruptura de la tregua (Villarraga Sarmiento, 2015, págs. 45-70).

No obstante, el proceso de paz con el M-19 fue el gran logro del dirigente Barco, pues logró constituir un proceso de paz con ese grupo al margen de la ley, el cual había encontrado amplia simpatía en la población, principalmente urbana. Por ese proceso de paz se logró, de manera histórica e inesperada, la principal votación en la elección de delegados para la Asamblea Nacional Constituyente. Según Villarraga, dentro de los efectos del proceso en cita no estaba el pacto de desmovilización del M19, "sino en la dinámica del proceso político y electoral, conjugada con el movimiento estudiantil y ciudadano, que incidió de manera determinante para hacer posible la ANC de 1991" (Villarraga Sarmiento, 2015, págs. 65).

En el año 1990 inició el mandato de César Gaviria, mediante el cual se dio continuidad a los procesos de paz anteriormente instaurados. En las negociaciones de paz del EPL, el PRT (Partido Revolucionario de los Trabajadores) y el MAQL (Movimiento Armado Quintín Lame) se aplicó un esquema de indulto, favorabilidad para el proyecto político surgido en la legalidad, participación en la constituyente e implementación de los programas de reinserción. Por otro lado, en relación con los diálogos con las FARC-EP y el ELN, el gobierno amplió su política de paz en términos de considerar la aceptación de una forma de veeduría internacional para todas 
las fases del proceso y un manejo amplio para acordar el temario de la mesa de negociación (Villarraga Sarmiento, 2015, págs. 83-97).

Sobre la negociación con los movimientos EPL, PRT y MAQL, entre los años 1990 y 1991, se produjo un nuevo reagrupamiento entre las guerrillas que quedaron activas: las FARCEP, la Unión Camilista Ejército de Liberación Nacional (UC-ELN) y la pequeña disidencia del EPL que desconoció los diálogos e intentó reconstruir ese movimiento con apoyo de las FARCEP. Retomaron la denominación de "Coordinadora Guerrillera Simón Bolívar" (CGSB) y, de manera coordinada, asumieron los diálogos con el Gobierno Nacional en Caracas en 1991 y en Tlaxcala en 1992. Por su parte, se produjo otra disidencia en el ELN, denominada Corriente de Renovación Socialista (CRS), la cual reconoció como válida la reforma constituyente e inició de manera independiente negociaciones con el gobierno, entre 1993 y 1994 (Villarraga Sarmiento, 2015, págs. 83-97).

Durante el gobierno de Gaviria se desmovilizaron el Ejército Popular de Liberación (EPL), el Partido Revolucionario de los Trabajadores (PRT), el Movimiento Armado Quintín Lame (MAQL), la Corriente de Renovación Socialista (CRS) y las Milicias Populares (MP).

En el Gobierno de Samper (1994-1998), donde se esperaba una ruta definitiva para marcar el proceso de paz, se congelaron las relaciones con las FARC-EP por el comunicado del Comandante del Ejército en el que se expresó que el militarismo se oponía a las gestiones de paz, de manera que las relaciones con las FARC-EP empeoraron. Sumado a esto, se dio la renuncia del Alto Comisionado para la Paz y el comienzo del Proceso 8000 que involucró a altos funcionarios del gobierno, con denuncias sobre utilización de recursos del narcotráfico en su proceso electoral, por lo que para 1995 la UC-ELN y el EPL, ante la declaratoria del estado de 
conmoción interior y el anuncio de fuertes medidas de confrontación con las guerrillas por parte del presidente Samper, dieron por cerradas las posibilidades del diálogo y la negociación de paz.

Para 1996 la UC-ELN, las FARC-EP y el ELN radicalizaron de nuevo su posición ante el gobierno, de forma que en las elecciones de 1997 declararon oposición total y desataron ataques contra el Estado que incluyeron arbitrarias actuaciones contra mandatorios locales, integrantes de corporaciones públicas y funcionarios públicos civiles así como presiones y amenazas contra la ciudadanía.

Con la firma del Acuerdo de Remolinos del Caguán, entre el Gobierno y las FARC-EP, en el que se consolidaron los términos para la entrega de algunos soldados, en reconocimiento de que las FARC-EP había cumplido con lo acordado, se asumieron nuevamente negociaciones por motivos humanitarios, por lo cual apareció la posibilidad de emprender un nuevo proceso de paz (Villarraga Sarmiento, 2015, págs. 101-133).

El expresidente Andrés Pastrana planteó una política por la paz no exenta de improvisación que fue negativa para el proceso. Uno de los casos particularmente significativos fueron las condiciones en que se dio la instalación de la Zona de Distensión con las FARC-EP, pues se convino una agenda común, se alcanzó a discutir el cese al fuego y las hostilidades, se consiguieron varios acuerdos parciales y hubo importantes intercambios; sin embargo, permanentemente existieron enfrentamientos, lo cual implicó repetidas suspensiones, deterioro del tratamiento de la agenda sustantiva y progresivo daño de las posibilidades. Esta guerrilla le dio prioridad al tema del canje humanitario. Según Villarraga "el gobierno, más allá de su disponibilidad para la formulación de la política, no hizo propuestas de reformas ni apuestas 
políticas y sociales a tono con el proceso de paz. Las negociaciones finalmente se rompieron y se retornó a las hostilidades" (Villarraga Sarmiento, 2015, págs.142-143).

Por su parte, en los diálogos con el ELN se ofrecieron garantías para desarrollar la Convención Nacional; pero, a pesar de algunas reuniones preparatorias, ambos propósitos se ahogaron en medio de graves incidentes causados por violaciones al derecho humanitario por parte de dicha guerrilla y por la ofensiva paramilitar dirigida a zonas de especial presencia del ELN, por lo que los diálogos se suspendieron (Villarraga Sarmiento, 2015). A pesar de ello, el gobierno, debido a la larga lista de grupos al margen de la ley y la consolidación del más grande de ellos, las FARC-EP, emprendió una búsqueda incansable por conseguir la paz en diferentes momentos y escenarios, teniendo intentos fallidos como los diálogos de paz del Caguán en 1997. (Calderón Rojas, 2016)

Finalmente, en el gobierno de Álvaro Uribe Veléz (2002-2010) se consolidó la política de seguridad democrática, la cual se construyó mediante tres líneas de acción: la primera, la continuación de la ofensiva contra las FARC; la segunda, una "política de paz" con los paramilitares; y, por último, un grupo de políticas sobre los soldados campesinos, las redes de informantes y los estímulos a la deserción (Leal Buitrago, 2006, p. 3).

Uribe abandonó la política de paz nacional y estatal, partiendo de la negación de la existencia misma del conflicto armado interno, pues, según él, solo existía una amenaza de carácter terrorista. Por esa razón, se implementó una ruptura con la anterior política que guiaba el Programa para la Reintegración y adoptó, en su lugar, una política de reinserción y reintegración 
que introdujo, a partir de los Decretos 128 de $2003^{2}$ y 2767 de $2004^{3}$, la obligación para las personas desmovilizadas de brindar información y colaborar en las acciones contra los grupos armados ilegales (Villarraga Sarmiento, 2015, p.190). Se estableció la llamada Zona de Ubicación y la Mesa de Negociación en Santafé Ralito, Tierralta, Córdoba, para el año 2004, con la concentración de los principales jefes paramilitares, acompañados de un contingente; aunque se lograron desarticular importantes contingentes paramilitares, no todos los desmovilizados registrados efectivamente lo eran, a la vez que buena parte de ellos mantuvo las funciones de control y apoyo al narcotráfico y a otros intereses ilegales y legales asociados.

Cuando fue aprobada por el Congreso la Ley 975 de 2005 (Ley de Justicia y Paz) ${ }^{4}$, reglamentada parcialmente por los Decretos Nacionales 4760 de 2005, 690 , 2898 y 3391 de 2006 y por el Decreto Nacional 3011 de 2013, se estableció un nuevo marco jurídico para la reincorporación a la vida civil de miembros de grupos armados organizados al margen de la ley, se incorporaron referencias a la atención de los derechos de las víctimas y a la necesidad de garantizar los derechos de las mismas, pero no se estipularon los mecanismos que los hicieran efectivos.

Dicha disposición normativa asimiló a la sedición como conducta de los paramilitares en aras de concederles indulto generalizado, pues existían muchos miembros de ese grupo comprometidos con conductas criminales masivas y sistemáticas contra la población. También otorgó grandes beneficios penales a quienes se sometieran al procedimiento especial, lo cual redujo al mínimo los implicados por el nivel de "impunidad" que produjo esa norma; declarar la

\footnotetext{
${ }^{2}$ Por el cual se reglamenta la Ley 418 de 1997, prorrogada y modificada por la Ley 548 de 1999 y la Ley 782 de 2002 en materia de reincorporación a la sociedad civil.

${ }^{3}$ Por el cual se reglamenta la Ley 418 de 1997, prorrogada y modificada por la Ley 548 de 1999 y la Ley 782 de 2002 en materia de reincorporación a la vida civil.

${ }^{4}$ Por la cual se dictan disposiciones para la reincorporación de miembros de grupos armados organizados al margen de la ley, que contribuyan de manera efectiva a la consecución de la paz nacional y se dictan otras disposiciones para acuerdos humanitarios.
} 
verdad no constituyó una obligación perentoria ni con consecuencias penales o sanción alguna; sobre la reparación no se cumplió con los propósitos que ella demandaba; y, con respecto a las garantías de no repetición, no hubo compromiso alguno (Congreso de la República de Colombia, 2005).

Luego de estudiar la historia del conflicto en Colombia, se torna inevitable resaltar que la mayoría de los gobiernos han intentado la Paz, como mandato constitucional, con los diversos grupos al margen de la ley que se han venido creando, acabados o consolidados en el pasar de los años, bajo los supuestos de un tratamiento especial de amnistía o indulto y de la conseción de participación política que podían llegar a exigir los movimiento revolucionarios que tenían su pensamiento dirigido hacia una sociedad igualitaria, y otros, vocerías con las que no contaban y que tal vez los llegó a motivar para alzarse en armas.

Como critero imparcial sobre el periodo en el que se llegó a acuerdos con los paramilitares, a pesar de buscar la paz y acabar con el conflicto armado en Colombia, se blindaron normas con el propósito de la desmovilización bajo parámetros de justicia precarios, en los cuales las normas suscritas en el transcurso de ese gobierno conrtribuyeron a la impunidad, sin que el marco normativo establecido para la época creara criterios firmes para garantizar la Verdad, Justicia, Reparación y No Repetición.

Lo anterior tiene relevancia debido a que esta investigación planteará en su hipótesis algunos parámetros para demostrar la inexistencia de impunidad en el Acuerdo de Paz (Gobierno Nacional-FARC-EP, 2016), el seguimiento de los estándares constitucionales e internacionales sobre la imposición de amnistías e indultos, de donde se destacan los presupuestos del Derecho Internacional Humanitario y los convenios internacionales ratificados por Colombia, por 
intermedio de las que se hace obligatoria la protección del derecho de las víctimas a la verdad para el otorgamiento de alivios penales.

\section{LA SUSCRIPCIÓN DEL ACUERDO FINAL PARA LA PAZ}

Desde el año 2012, el gobierno de Juan Manuel Santos inició conversaciones con la guerrilla de las FARC-EP con base en una agenda de 6 puntos, sobre los cuales se fueron logrando acuerdos parciales, hasta llegar a la conformación total del Acuerdo Para la Paz en el año 2016, cuando fue firmado por el Gobierno Nacional y las FARC-EP, en primera instancia, en la Habana (Cuba).

Dicho acuerdo busca, fundamentalmente, la construcción de una paz estable y duradera, en concordancia con los términos del preámbulo y el acápite de derechos fundamentales de la Constitución Política de Colombia (1991), Artículo $22^{5}$, donde se establece que la paz es un fin del estado y también un derecho fundamental de los colombianos. Se suma, además, lo dispuesto por la comunidad internacional que se comprometió a luchar por la protección del derecho a la paz (Asamblea General de las Naciones Unidas, 1984) y que es considerado desde el preámbulo

\footnotetext{
${ }^{5}$ El pueblo de Colombia, en ejercicio de su poder soberano, representado por sus delegatarios a la Asamblea Nacional Constituyente, invocando la protección de Dios, y con el fin de fortalecer la unidad de la Nación y asegurar a sus integrantes la vida, la convivencia, el trabajo, la justicia, la igualdad, el conocimiento, la libertad y la paz, dentro de un marco jurídico, democrático y participativo que garantice un orden político, económico y social justo, y comprometido a impulsar la integración de la comunidad latinoamericana, decreta, sanciona y promulga la siguiente

(...)

Artículo 22. La paz es un derecho y un deber de obligatorio cumplimiento.

Artículo 22A. Adicionado por el art.1, Acto Legislativo 05 de 2017. con el siguiente texto: Como una garantía de No Repetición y con el fin de contribuir a asegurar el monopolio legítimo de la fuerza y del uso de las armas por parte del Estado, y en particular de la Fuerza Pública, en todo el territorio, se prohíbe la creación, promoción, instigación, organización, instrucción, apoyo, tolerancia, encubrimiento o favorecimiento, financiación o empleo oficial y/o privado de grupos civiles armados organizados con fines ilegales de cualquier tipo, incluyendo los denominados autodefensas, paramilitares, así como sus redes de apoyo, estructuras o prácticas, grupos de seguridad con fines ilegales u otras denominaciones equivalentes.

La ley regulará los tipos penales relacionados con estas conductas, así como las sanciones disciplinarias y administrativas correspondientes.
} 
de la Declaración Universal de Derechos Humanos ${ }^{6}$ como un derecho humano de obligatorio cumplimiento por los Estados miembros (Asamblea general de las Naciones Unidas, 1948).

Sin embargo, en contravención de la suscripción de dicho Acuerdo, este no fue refrendado en el plebiscito adelantado el 2 de octubre de 2016, porque el "no" se impuso con 6.422.136 votos, el 50,23 \% de votos, mientras que el "sí" reunió un total de 6.361 .762 votos $^{7}$ (Arango, 2016).

Ahora, luego de reformar algunos puntos en los que la oposición al gobierno de Santos insistía en cambiar, se firmó el acuerdo definitivo en el Teatro Colón de Bogotá D.C., refrendado por el Congreso de la República de Colombia, en sesión plenaria del Senado celebrada el 29 de noviembre de 2016, aprobado por inmensa mayoría ${ }^{8}$, y en sesión plenaria de la Cámara de Representantes del 30 de noviembre de 2016, fue acogido con el voto favorable de una amplia mayoría ${ }^{9}$, por lo cual se legitimó lo pactado. Lo anterior, debido a que el Acto Legislativo 01 de 2016, mediante el cual se establecen instrumentos jurídicos para facilitar y asegurar la implementación y el desarrollo normativo del Acuerdo Final para la Terminación del Conflicto y la Construcción de una Paz Estable y Duradera (2016), condicionaba la entrada en vigencia del acuerdo a la refrendación popular (Congreso de la República de Colombia, 2016).

Posteriormente, en revisión de la Corte Constitucional, sobre la legitimación que le dio el Congreso de la República al acuerdo, se entró a verificar si se cumplió el requisito de la refrendación popular del Acuerdo Final previsto en la precitada disposición. Esa corporación, entre otras cosas, debía observar que se cumpliera con las siguiente características determinadas

\footnotetext{
${ }^{6}$ Considerando que la libertad, la justicia y la paz en el mundo tienen por base el reconocimiento de la dignidad intrínseca y de los derechos iguales e inalienables de todos los miembros de la familia humana.

${ }^{7} \mathrm{https} / / /$ elecciones.registraduria.gov.co/pre_plebis_2016/99PL/DPLZZZZZZZZZZZZZZZZZ_L1.htm

${ }^{8}$ Acta de Plenaria 41, del 29 de noviembre de 2016, en Gaceta del Congreso 53, Bogotá, 7 de febrero de 2017.

${ }^{9}$ Acta de Plenaria 186, de 30 de noviembre de 2016, en Gaceta del Congreso 65, Bogotá, 9 de febrero de 2017.
} 
en la línea jurisprudencial de la corporación: designar un proceso, en el cual haya participación ciudadana directa, cuyos resultados deben ser respetados, interpretados y desarrollados de buena fe, en un escenario de búsqueda de mayores consensos, proceso que puede concluir en virtud de una expresión libre y deliberativa de una autoridad revestida de legitimidad democrática, sin perjuicio de eventuales espacios posibles de participación ciudadana para la revisión específica de aspectos concretos ulteriores. De tal forma que, mientras los órganos políticos encargados de aplicar las previsiones del Acto Legislativo 01 de 2016 se mantengan dentro de esos límites, puede definirse que sí se ha cumplido la Refrendación Popular, que es condición para su entrada en vigencia (Corte Constitucional, C-699, 2016).

Al respecto y en definitiva, sobre la refrendación del Acuerdo Final para la Paz, la Corte Constitucional consideró que sí se cumplió con dichos requisitos, porque el complejo proceso de negociación de paz se desarrolló de manera consensual y de buena fe entre el Gobierno Nacional y las FARC-EP; fue participativo y reflexivo, en cuanto tomaron participación las víctimas, los partidos políticos, los voceros del no y la ciudadanía en general; fue consultivo y democrático en virtud del plebiscito especial y la aprobación por el Congreso; estuvo precedido por el acompañamiento de países garantes como Cuba, Noruega, Chile, Venezuela y las Naciones Unidas; tuvo cabida la regulación normativa como actos legislativos, leyes y decretos reglamentarios por el Congreso y el Gobierno, además del control judicial de constitucionalidad sobre actos legislativos y leyes, como se hizo en la Sentencia C-699 de 2016, que declaró exequibles, por los cargos examinados, los artículos 1 y 2, parciales, del Acto Legislativo 01 de 2016.

Igualmente, arguyó esa corporación, para la construcción del Acuerdo Final para la Paz se trataron de conciliar dos principios que se encuentran en tensión en los fundamentos de la 
cláusula de vigencia del Acto Legislativo 01 de 2016: "por una parte, la garantía del valor, principio y derecho fundamental a la paz y, por la otra, la necesidad de construir la paz a través de una política pública que se desarrolle mediante una dinámica de participación ciudadana amplia y democrática, en la cual participe directamente el pueblo." (Corte Constitucional, C160 de 2017)

Textualmente, concluyó la Corte Constitucional en Sentencia C-160 de 2017, lo siguiente:

Así, el proceso de Refrendación Popular, al estar articulado por instancias de la democracia directa y de la democracia representativa, viabiliza el ejercicio de las competencias constitucionales del Presidente de la República, con el fin de alcanzar la paz (CP art. 22, 83, 188 y 189). Pero, al mismo tiempo, al exigir intervención ciudadana directa y efectividad de sus resultados a través de un deber de interpretación, respeto y desarrollo de buena fe, en un escenario de búsqueda de mayores consensos, protege el principio democrático y le da poder al pueblo para reorientar la concreción de la política de paz.

En este orden de ideas, la Sala Plena encuentra cumplidos los requisitos fijados por esta misma Corporación para la Refrendación Popular y la vigencia del Acto Legislativo 01 de 2016. (Corte Constitucional, C-160 de 2017)

De lo expuesto se colige que en una sociedad democrática es posible debatir o cuestionar las decisiones de los jueces, empero la decisión adoptada por el ejecutivo, el legislativo y el judicial es evidentemente irreprochable jurídicamente, toda vez que se evidencian ampliamente cumplidas las exigencias de la refrendación popular establecidas en el Acto Legislativo 01 de 
2016, por lo que es plenamente vigente y vinculante (Poveda Perdomo, Poveda Perdomo, \& Poveda Rodríguez, Problemas Hermenéuticos de la Ley de Amnistía, 2017).

Finalmente, luego de la refrendación y la verificación realizada por la Corte Constitucional, el Acuerdo Final para la Paz quedó en firme y conformado por 6 puntos consistentes en lo siguiente: (1) reforma rural integral, (2) participación política, (3) cese al fuego y de hostilidades bilateral y definitivo y dejación de las armas, (4) solución al problema de los cultivos ilícitos, (5) acuerdo de víctimas que comprende el sistema integral para la reparación de las víctimas e incluye la Jurisdicción Especial para la Paz y (6) los mecanismos de implementación y verificación (Gobierno Nacional-FARC-EP, 2016).

\section{ACUERDO FINAL PARA LA PAZ: LINEAMIENTOS SOBRE EL DERECHO A} LA VERDAD, AMNISTÍAS E INDULTOS

Luego de aceptado el conflicto armado en Colombia y con el fin de terminar con este, el Gobierno Nacional y las FARC-EP, al final de unos prolongados diálogos, suscribieron el Acuerdo Final para la Terminación del Conflicto y la Construcción de una Paz Estable y Duradera ${ }^{10}$, tal y como quedó expuesto en lo anterior. En dicho acuerdo se consagran, entre otras cosas, los lineamientos mediante los cuales van a ser garantizados los derechos de las víctimas a la Verdad, Justicia, Reparación y No Repetición, de manera que en la implementación de dichos acuerdos debe cumplirse lo pactado, impactando la realidad nacional en diferentes ámbitos, entre ellos el normativo.

\footnotetext{
${ }^{10} \mathrm{Cfr}$.http://www.altocomisionadoparalapaz.gov.co/procesosyconversaciones/Documentos\%20compartidos/24-112016NuevoAcuerdoFinal.pdf.
} 
El acuerdo tiene como objetivo principal obtener una paz estable y duradera y, en ese sentido, llegar al fin del conflicto armado con las FARC-EP. Dejó especialmente delimitado, en el punto 5, el acuerdo sobre víctimas del conflicto armado, donde se estableció todo acerca del sistema integral de Verdad, Justicia, Reparación y No Repetición, incluyendo la Jurisdicción Especial para la Paz y el compromiso sobre Derechos Humanos; es decir, todos los derechos de las víctimas. Ello con el fin de dar un contenido que satisfaga las necesidades de quienes han sido afectados por el conflicto armado; esto es, la comunidad en general y, especialmente, las víctimas directas de graves violaciones a Derechos Humanos.

Lo anterior tiene consonancia con la teoría sobre el bien común desplegada por Tomás de Aquino, por lo que, integrándola al sub examine, el Acuerdo puede llegar a ser la fórmula para la construcción de la convivencia pacífica. Específicamente, el profesor Cárdenas consideró lo siguiente, con base en las teorías de Aquino:

La estructura de lo acordado ya es una formulación parcial de elementos claves del bien común, que no es meramente una aspiración, sino un conjunto articulado de posibilidades para transformar la convivencia (...) No se necesita apelar a un significante sin referente para que se concrete lo que el Aquinate exige del bien común: "la posesión suficiente de todos los bienes capaces de asegurar el mejor rendimiento de la vida y de sus operaciones" (S.T, I-II, 3, 3 ad 2m), todo lo cual es factor de paz en proceso de realización convivencial, más allá del mero "pacto" o "acuerdo", que aún no es sino voluntad de desarme. (Cardenas Sierra, 2017)

Para lo anterior, como punto neurálgico para la implementación de dicho acuerdo se tuvo en cuenta el esclarecimiento de la verdad, mediante el cual se busca establecer y esclarecer lo 
sucedido a lo largo de conflicto armado, con el fin de determinar sus causas, orígenes y efectos como parte fundamental de la protección de los derechos a las víctimas, teniendo como objetivo principal la reconstrucción de la confianza por parte de los ciudadanos hacia el Estado colombiano.

Por esas razones, el Sistema Integral de Verdad, Justicia, Reparación y No Repetición, con la creación de la Comisión para el Esclarecimiento de la Verdad, la Convivencia y la No Repetición, busca contribuir a elucidar las violaciones e infracciones y ofrecer una explicación amplia de la complejidad del conflicto a toda la sociedad, a través de la aceptación de responsabilidad por parte de los partícipes en las conductas delictivas que vulneraron Derechos Humanos e infringieron el Derecho Internacional Humanitario y, de esta forma, poder garantizar el derecho a la verdad de las víctimas, el reconocimiento de las mismas y la promoción de la convivencia territorial (Gobierno Nacional-FARC-EP, 2016, págs. 130-132).

De igual manera, en el Acuerdo Final para la Paz (2016), se crea la base de justicia para luchar contra la impunidad con mecanismos judiciales que contribuyan en la búsqueda de la verdad. De manera que, a partir de la creación de la Jurisdicción Especial para la Paz como base de Justicia, se establecen los derroteros mediante los cuales también se va a buscar la verdad de lo ocurrido durante el conflicto, para lo cual, se crea la Sala de Reconocimiento de la Verdad y Responsabilidad y la Sala de Amnistías o Indultos.

Para lo consignado, se establecieron los contenidos, alcances y límites de la concesión de amnistías e indultos así como de otros tratamientos especiales, a los cuales están sujetas las Salas o Unidades judiciales que pudieran otorgar dichas prerrogativas, entre las cuales encontramos: (i) que la finalidad del sistema integral es la consolidación de la paz y la garantía de los derechos de 
las víctimas; (ii) que debe existir seguridad jurídica, que los marcos jurídicos principales son el derecho internacional en materia de Derechos Humanos, el Derecho Internacional Humanitario, el derecho penal internacional y el Código Penal para tipificar la conducta, siempre con aplicación obligatoria del principio de favorabilidad; (iii) que las víctimas sean oídas; (iv) que deben asegurarse los derechos de las víctimas respecto de graves violaciones al Derecho Internacional Humanitario (DIH) y a los Derechos Humanos; (v) que existe el deber de investigar, esclarecer, perseguir y sancionar las graves violaciones al DIH; (vi) que se puede otorgar la amnistía más amplia posible a personas que hayan sido acusados de delitos políticos o conexos; (vii) que hay delitos que no son amnistiables ni indultables por ser crímenes de lesa humanidad y otros definidos en el Estatuto de Roma; (viii) que se adoptará una norma sobre amnistía e indulto bajo los principios de favorabilidad; (ix) que las amnistías e indultos están sometidas a la contribución, individual o colectiva, al esclarecimiento de la verdad; (x) que dependiendo del grado de verdad aportada será el tratamiento especial a recibir; (xi) que se establecerán las sanciones para los delitos no sujetos a amnistía e indulto; (xii) que serán de conocimiento de la JEP los asuntos de los agentes del Estado colombiano que hubieren cometido delitos relacionados con el conflicto armado; y, (xiii) que la imposición de sanciones no inhabilitará la participación política (Gobierno Nacional-FARC-EP, 2016, págs.147-152).

Es así, que la Sala de Reconocimiento de la Verdad y Responsabilidad debe marchar entorno a resolver las conductas que son competencia del Sistema y fijar los plazos para las declaraciones donde se reconozca la verdad y la responsabilidad, con la finalidad de imponer las sanciones correspondientes a los máximos responsables y establecer las conductas que no han sido reconocidas para que sean investigadas por la Unidad de Investigación y Acusación, definir los sujetos que no son susceptibles de amnistías o indultos y realizar las recomendaciones 
pertinentes sobre los hechos que fueron esclarecidos para la aplicación de prerrogativas en la Sala de Amnistías e Indultos (Gobierno Nacional-FARC-EP, 2016, págs.154-157).

Consecuentemente, la Sala de Amnistías e Indultos otorgará amnistías e indultos en los casos de las personas condenadas o investigadas por delitos que ameriten dichas prerrogativas, conforme lo dispuesto por la Ley creada para regular los alivios penales. En caso de que el victimario no sea sujeto a ningún alivio penal, se remitirá a la Sala de Reconocimiento de la Verdad (Gobierno Nacional-FARC-EP, 2016, págs.157-158). Por su parte, la Sala de decisión de Situaciones Jurídicas resolverá los casos de agentes que no hayan sido sujetos a amnistía e indultos, los que no han reconocido verdad y responsabilidad (Gobierno Nacional-FARC-EP, 2016, p.158). En caso de que sea imposible el reconocimiento de la verdad del conflicto armado, el Acuerdo previó la investigación de los delitos con el fin de garantizar la verdad a las víctimas y esculcar la posible responsabilidad en alguno de los hechos del conflicto armado interno, para así hacer prevalecer el marco de justicia (Gobierno Nacional-FARC-EP, 2016, págs. 159-160).

Sobre el reconocimiento de la verdad existen dos posibilidades para los integrantes de grupos al margen de la ley que suscriban el acuerdo o agentes del Estado sujetos al marco de este; por un lado, encontramos la Sección de Primera Instancia del Tribunal para la Paz en casos de reconocimiento de verdad y responsabilidad que evalúa la correspondencia entre las conductas cometidas, los responsables de las mismas y las sanciones a partir de la resolución proferida por la Sala de Reconocimiento de la Verdad, que de ser aprobada, procederá a imponer la sanción dispuesta en dicha decisión, fijará la forma de la ejecución y supervisará el cumplimiento; por el otro lado, encontramos la Sección Primera del Tribunal para casos en que no se ha reconocido la verdad y la responsabilidad, casos en los cuales debe someterse a las personas a un juicio contradictorio y en dado caso sancionarlos o absolverlos, sin perjuicio de 
que antes de proferir sentencia reconozcan la verdad y su responsabilidad; en ese caso, se impondrán las sanciones alternativas previstas en el listado de sanciones (Gobierno NacionalFARC-EP, 2016, 161-162).

Finalmente, como garantía para los victimarios, se estableció la Sala de Revisión del Tribunal para la Paz, en donde se revisan las decisiones condenatorias adoptadas y decisiones del componente de justicia cuando haya mérito para ello, además de poder pronunciarse sobre solicitudes de las diferentes Salas y conflictos de competencias entre ellas (Gobierno NacionalFARC-EP, 2016).

Todo lo expuesto, teniendo como base los principios establecidos para la implementación del Acuerdo, referentes al reconocimiento de las víctimas, la responsabilidad, la satisfacción de sus derechos, la participación, el esclarecimiento de la verdad, la reparación, las garantías de protección y seguridad, la no repetición, la reconciliación y el enfoque de derechos, todos aquellos que ayudan al cumplimiento del Acuerdo y la prevalencia de los derechos de las víctimas (Gobierno Nacional-FARC-EP, 2016, págs.124-126). Esto quiere decir que las sanciones tienen como finalidad esencial y especifica la garantía de los derechos de las víctimas, entre otros, como ya lo hemos expuesto, el derecho a la verdad, pues, es el único derecho que está sometido relevantemente a su protección, so pena de la desestimación de imposición de amnistía o indulto alguno, lo que denota de sobre manera su importancia en el proceso de justicia transicional que está en proceso de implementación en Colombia.

En el orden de las ideas planteadas, conforme a los procesos de paz adelantados en el transcurso de la historia en Colombia, el Acuerdo Final para la Paz y su desarrollo en torno a la justicia transicional como base de la reconciliación, en la parte primera de la exploración se 
adelantará un examen pormenorizado sobre las influencias, alcances y límites de la garantía del derecho a la verdad de las víctimas y las instituciones amnistías e indulto. 


\section{PRIMERA PARTE}

\section{EL DERECHO A LA VERDAD DE LAS VÍCTIMAS Y LAS INSTITUCIONES AMNISTÍA E INDULTO PARA UN PROCESO DE RECONCILIACIÓN NACIONAL}

Los capítulos que se abordarán a continuación se encargarán de desglosar los conceptos claves de la presente investigación, como lo son el derecho a la verdad como derecho humano y fundamental y la amnistía y el indulto como instituciones de carácter político; específicamente, se examinará el contenido y alcance del derecho a la verdad en el derecho internacional y en el marco del Acuerdo Final para la Paz, además de realizar un desarrollo de las instituciones amnistía e indulto desde la perspectiva constitucional y el Acuerdo Final de Paz.

\section{CAPÍTULO PRIMERO}

\section{EL DERECHO A LA VERDAD DE LAS VÍCTIMAS DEL CONFLICTO ARMADO: ESPECIAL REFERENCIA AL CASO COLOMBIANO}

\section{EL DERECHO A LA VERDAD Y LAS VÍCTIMAS}

Para entender los alcances y límites del derecho a la verdad de las víctimas del conflicto armado en Colombia, es indispensable profundizar de forma sucinta sobre lo que es un derecho fundamental en Colombia, las teorías sobre la verdad, el concepto de derecho a la verdad de las víctimas y los desarrollos normativos y jurisprudenciales que se han dado con relación a la protección de ese derecho en particular. 


\subsection{Algunos acercamientos a la definición de los derechos fundamentales}

La definición de derecho no ha sido pacífica, aún menos la de derecho fundamental. Por ello, para entender qué es un derecho fundamental, necesitamos sentar una postura sobre el concepto y así mismo desarrollar el texto con base en esos criterios reguladores del pensamiento que han establecido algunos autores muy relevantes en la historia de la ciencia del derecho, de tal forma que el proceso de la elaboración de este documento tesis sea consecuente con su contenido.

De esa manera, hay que poner en relevancia la circunstancia de que el derecho ha sido fenómeno histórico perteneciente a sociedades concretas, y que para definirlo debe ponerse en correlación con el concepto de norma, moral y poder. Por ejemplo, Manuel Atienza, citando a Marx, considera que la idea de derecho surge del conflicto entre las clases sociales y que, en consecuencia, es un fenómeno histórico que acompaña únicamente al desarrollo de cierto tipo de sociedades. Por ello, para hablar de derecho, debe existir un aparato institucional que monopolice la fuerza (Atienza, 2007, p. 23).

Por otro lado, Atienza, al citar a Kelsen, entiende el derecho como un sistema dinámico que regula su propia creación: una determinada norma es válida si ha sido creada en conformidad con los procedimientos establecidos en otra norma de grado superior; esto nos lleva hasta una última norma cuya validez no puede derivarse ya de otra superior: la norma fundamental (Atienza, 2007, p. 290).

Ahora bien, si correlacionamos las normas jurídicas, la moral y el poder, podemos entender que el derecho son las normas jurídicas "en función de los fines particularmente relevantes para la sociedad, como la protección de la vida y de la seguridad de los asociados y la distribución 
de los bienes, inevitablemente insuficientes para satisfacer por completo las demandas de cada asociado" (Faralli, 2007, p. 15). Ergo, los derechos son aquellos derivados de las normas jurídicas que son expedidas legítimamente por el ente del Estado que las crea y son válidas si presentan el procedimiento dispuesto en una norma de carácter superior; sin embargo, el derecho también es el encargado de brindarle las garantías y libertades necesarias a las personas para vivir en una sociedad.

También, sobre los derechos fundamentales, Ferrajoli consideró que son todos aquellos derechos subjetivos que corresponden universalmente a todos los seres humanos dotados de personalidad con capacidad de ser titular de situaciones jurídicas, entendiendo por derecho subjetivo cualquier expectativa positiva adscrita en una norma jurídica, tipificada en las leyes y constituciones de las actuales democracias (Ferrajoli, 1999, p. 37).

Sobre lo anterior, se puede inferir que los derechos fundamentales son aquellos que están positivizados, pero específicamente, como lo estableció Fioravanti, aquellos derivados de la constitución que buscan garantizar los derechos y las libertades de los ciudadanos, "como una norma directiva fundamental a seguir para la realización de los valores constitucionales" (Fioravanti, 1996, págs. 128-129).

Con todo, hace bien el profesor Robert Alexy al manifestar que las normas fundamentales confieren derechos subjetivos, sin perjuicio de que existan normas del catálogo de derechos fundamentales que no pueden ser llamadas normas de derecho fundamental, por cuanto el concepto de norma fundamental es un concepto que puede ser manejado de forma más amplia que el de derecho fundamental que vendría siendo más restringido (Alexy, 1997, págs. 48-49). 
Lo anterior, por cuanto, en consideración de Alexy, no todas las normas de la Ley fundamental (para el caso alemán) o Constitución política (para el caso colombiano), contiene un derecho fundamental, porque para él interfiere el carácter formal de la norma, en donde solamente las normas enunciadas en el capítulo de derechos fundamentales tienen el carácter de derecho fundamental. Sin embargo, una norma que no se encuentre en dicho título puede ser de derecho fundamental siempre y cuando se fundamente en el marco de un derecho fundamental estatuído (Alexy, Teoría de los derechos fundamentales, 1997, págs. 72-73). Los derechos fundamentales, en general, son aquellos que establece la norma fundamental o Constitución, dependiente del régimen democrático al que nos refiramos, y los derivados de aquellos, que pretenden proteger las libertades del individuo y brindar condiciones de igualdad ante el Estado y la sociedad.

En casos específicos como el colombiano, los derechos fundamentales están establecidos en la Constitución Política de Colombia (1991), pero también se han venido desarrollando por interpretaciones normativas realizadas por la Corte Constitucional colombiana, sumado a que por el bloque de constitucionalidad pueden llegar a ser denominados derechos fundamentales algunos Derechos Humanos establecidos en la declaraciones u convenios internacionales que han sido ratificados por Colombia.

\subsection{Teorías sobre la verdad}

Desde los años 1200 A.C., los filósofos griegos se refirieron a "la verdad de las cosas y accesoriamente a nuestro conocimiento. En este caso, le denominan con el término alétheia, esto es, lo que no está "oculto" y/o "desocultamiento"” (Zamora Acevedo, 2014, p. 152); también, se pueden señalar épocas en las cuales la verdad ha estado por completo ausente del panorama de 
la investigación filosófica (Edad Media) a causa de una ferviente creencia en la existencia de Dios y de las sagradas escritura; y otras épocas en que la verdad ocupó un lugar especial en la filosofía.

En ese entendido, aceptamos que el concepto o teoría sobre la verdad ha sido desarrollado desde la filosofía. Una de las principales teorías de la verdad fue creada por Martin Heidegger, quien fue citado por el doctor Ruiz en una de sus obras, donde explica cómo Heidegger estableció que la verdad es el develamiento del ser, que es producida cuando se retira todo aquello que sobra de la persona para poder tenerla tal cual es, de manera que la esencia de la verdad es la libertad porque con ella puede develarse lo oculto (Ruiz Monroy, 2016).

Por otro lado, Habermas considera que la verdad se ha definido como: "las creencias implícitamente tenidas por verdaderas que rigen la acción controladas por el éxito y las pretensiones de verdad implícitamente sostenidas en la acción comunicativa se corresponden a la suposición de un mundo objetivo de objetos que manipulamos y enjuiciamos. Los hechos los afirmamos de los objetos mismos" (Habermas, 2007, p. 51).

Lo que quiere decir la teoría es que la verdad solamente es hallada después de buscar en lo oscuro y que nuestra verdad es aquella que vivimos o que somos. Los criterios de verdad explicados desde la filosofía, atienden a conceptos relativizados que intentan explicar el ser y el deber ser de las cosas. Para el caso que nos atañe, la verdad de las víctimas se encuentra en el silogismo de: si yo no conozco la verdad de lo ocurrido en el conflicto armado, mi verdad es diferente; las creencias, como lo dice Habermas (2007), son tenidas como verdaderas, mientras que no se devele lo oculto, como lo indica Heidegger (2016). 


\subsection{Derecho a la verdad de las víctimas y su aplicabilidad en Colombia}

Resaltan algunos tratados internacionales que las víctimas de graves violaciones de los Derechos Humanos y del Derecho Internacional Humanitario, así como sus familiares, tienen el derecho a la verdad como forma de reparación por los perjuicios causados; ello implica conocer la verdad sobre todo lo ocurrido, "incluyendo la posibilidad de identificar a los perpetradores, las causas que originaron tales violaciones y, de ser el caso, la suerte final o el paradero de las personas desaparecidas de manera forzada" (Centro Internacional para la Justicia Trancisional, 2013, p. 7). Por su parte, el Protocolo Adicional I a las Convenciones de Ginebra de 1949 (Convención de Ginebra, 1977), relativo a la protección de las víctimas de los conflictos armados internacionales, estableció, entre otras cosas, los elementos para dar garantías fundamentales a las personas en poder de los grupos al margen de la ley y la protección de las mujeres y los niños víctimas del conflicto.

Igualmente, la Convención Internacional para la Protección de Todas las Personas Contra las Desapariciones Forzadas (ICCPED), estableció "el derecho a conocer la verdad sobre las circunstancias de una desaparición forzada y la suerte de la persona desaparecida, así como el respeto del derecho a la libertad de buscar, recibir y difundir informaciones a este fin" (Naciones Unidas, 2010), como también lo hizo su Artículo 24, numeral 2, en el que se determinó que cada víctima tiene el derecho de conocer la verdad sobre las circunstancias de la desaparición forzada, la evolución y los resultados de la investigación y la suerte de la persona desaparecida, por lo que los Estados parte de dicho convenio deberán tomar las medidas adecuadas con el fin de garantizar que dichos derechos sean concedidos a las víctimas. 
Es importante aclarar que el referido convenio internacional (ICCPED), en el Artículo 24, numeral 1, dispuso que "se entenderá por "víctima" la persona desaparecida y toda persona física que haya sufrido un perjuicio directo como consecuencia de una desaparición forzada» (Naciones Unidas, 2010).

En el mismo sentido, la Convención Americana sobre Derechos Humanos, conforme a las disposiciones que amparan el derecho a un juicio justo, libertad de pensamiento y expresión y el derecho a la protección judicial, contiene el derecho de las víctimas a conocer la verdad de lo ocurrido durante las hostilidades o el conflicto armado interno (Organización de Estados Americanos, 1969), pero considera víctmas, al igual que la Corte Interamericana de Derechos Humanos, a todas aquellas que han soportado el conflicto armado de forma directa o indirecta, como los son las víctimas inmediatas, los familiares y las personas pertenecientes a un Estado en Conflicto.

Sobre el derecho a la verdad de las víctimas en mención, la Corte Interamericana de Derechos Humanos lo ratificó, en sentencias mediante las que ha sostenido lo siguiente: (i) la obligación que tiene el Estado parte de proveer a las familias de las víctimas la verdad sobre las circunstancias relativas a los crímenes cometidos por los grupos al margen de la ley (caso Velásquez Rodríguez vs. Honduras, 1988); (ii) el resultado de todos los procedimientos investigativos debe ser divulgado al público para que la sociedad conozca la verdad (caso Myrna Mack Chang vs. Guatemala , 2003); (iii) la sociedad tiene el derecho a saber la verdad relacionada con los crímenes con fines de prevención hacia el futuro (caso Bámaca Velásquez vs. Guatemala , 2000); y, (iv) si se profieren normas que contengan amnistías que en su fondo impidan la investigación de los hechos sobre violaciones graves a los Derechos Humanos y el 
establecimiento de responsabilidades, no están permitidas bajo la interpretación que le da la Corte al derecho internacional de los Derechos Humanos (caso Barrios Altos vs. Perú , 2001).

El derecho a la verdad en Colombia consiste en que las víctimas y sus familiares conozcan la verdad sobre los hechos que padecieron, los responsables de los mismos y las consecuencias de lo sucedido. Este derecho apareja, por tanto, el derecho a conocer la autoría del crimen, los motivos y las circunstancias de tiempo, modo y lugar en que ocurrieron las conductas delictivas y, finalmente, el patrón criminal que imperó en la ejecución de las acciones criminales. Esto último, implica el derecho a conocer si el delito que fue cometido constituye una grave violación a los Derechos Humanos, un crimen de guerra o un crimen de lesa humanidad (Corte Constitucional, 2012).

Ahora bien, el derecho a la verdad ha sido definido por los organismos internacionales como un derecho humano de obligatoria protección en los Estados donde, por la existencia de un conflicto armado interno, se han presentado flagrantes violaciones a los derechos de las personas que no tenían que soportar las acciones ilegales desplegadas por los rebeldes en contra de Estado.

La violación del derecho a la verdad se hace evidente cuando falta la información completa, objetiva y veraz sobre lo sucedido durante los largos períodos de violaciones graves a Derechos Humanos, por la creación de una política de Estado que impida divulgar información e, incluso, por una estrategia de guerra, razón por la cual se convierte en uno de los pilares de los mecanismos de justicia transicional, con el fin de orientar la divulgación de los estándares de verdad, mediante la sistematización del marco jurídico aplicable (Comisión Interamericana de Derechos Humanos, 2014, págs. 4-9). 
Teniendo en cuenta las definiciones y garantías que dan las normas internacionales al derecho a la verdad en el caso de la existencia del conflicto armado en Colombia, según los términos del Artículo 93 de la Constitución Política (1991), los tratados sobre Derechos Humanos ratificados, como la Convención Americana sobre Derechos Humanos precitada, ocupan un lugar en el ordenamiento jurídico y deben ser utilizados como criterio de interpretación de los derechos contemplados en dichos pactos internacionales, que, según la Corte Constitucional ${ }^{11}$, forman parte del bloque de constitucionalidad y, en ese sentido, son de obligatorio cumplimiento, porque todos los poderes públicos de un Estado deben cumplir con el control de convencionalidad ${ }^{12}$.

Lo anterior, teniendo en cuenta que los organismos internacionales han considerado que, a pesar de que el derecho a la verdad no está contenido expresamente en el texto de la Convención Americana sobre Derechos Humanos (1969), como se mencionó, encuentra un fundamento claro en los artículos 1,8 y 25 de la Convención, en donde se establecen las obligaciones estatales de respeto y garantía plena de los derechos consagrados en la Convención (Artículo 1): (i) de protección del derecho al debido proceso (Artículo 8) y (ii) de garantía de un recurso judicial efectivo (Artículo 25); razón por la cual tales compromisos se extienden al deber de esclarecimiento de las violaciones de los Derechos Humanos garantizados por la Convención, el castigo a los responsables y el establecimiento de medidas que garanticen la no repetición de

\footnotetext{
${ }^{11}$ Al respecto se puede ver sentencia C-010 de 2000, donde se indica que la Corte Constitucional coincide con que, en esta materia, es particularmente relevante la doctrina de la Corte Interamericana de Derechos Humanos, como órgano judicial autorizado para interpretar la Convención Interamericana, de manera tal que, como lo ha señalado en varias oportunidades la Corte Constitucional, en la medida en que la Carta señala en el artículo 93 que los derechos y deberes constitucionales deben interpretarse "de conformidad con los tratados internacionales sobre Derechos Humanos ratificados por Colombia", razón que hace indudable que la jurisprudencia de las instancias internacionales, encargadas de interpretar esos tratados, constituye un criterio hermenéutico relevante para establecer el sentido de las normas constitucionales sobre derechos fundamentales.

${ }^{12}$ El control de convencionalidad: el Poder Judicial debe ejercer una especie de "control de convencionalidad" entre las normas jurídicas internas que aplican en los casos concretos y la Convención Americana sobre Derechos Humanos. En esta tarea, el Poder Judicial debe tener en cuenta no solamente el tratado, sino también la interpretación que del mismo ha hecho la Corte Interamericana, intérprete última de la Convención Americana. Sentencia del 26 de septiembre de 2006. Caso Almonacid Arellano y otros Vs. Chile. Excepciones Preliminares, Fondo, Reparaciones y Costas.
} 
tales actos (Uprimny Yepes \& Saffon Sanín, 2006, p. 143), lo que permite la inclusión del derecho a la verdad en dichas disposiciones.

De ahí que la Corte Constitucional Colombiana en sentencia C-715 de 2012 hizo un análisis exhaustivo sobre la inclusión del derecho a la verdad, justicia y reparación como derechos de las víctimas por bloque de constitucionalidad, en el cual concluyó que los mismos eran, en el marco del derecho internacional, Derechos Humanos que deben ser acatados por el Estado colombiano. Por otro lado, analizando el marco jurídico nacional, manifestó que los derechos de las víctimas a la verdad, justicia y reparación son derechos constitucionales, en virtud de la interpretación de los Artículos $2^{13}, 29^{14}, 93^{15}, 229^{16}$ y 250 , Numerales 6 y $7^{17}$, de la Constitución Colombiana (Asamblea Nacional Constituyente, 1991), concluyendo lo siguiente:

\footnotetext{
${ }^{13}$ Son fines esenciales del Estado: servir a la comunidad, promover la prosperidad general y garantizar la efectividad de los principios, derechos y deberes consagrados en la Constitución; facilitar la participación de todos en las decisiones que los afectan y en la vida económica, política, administrativa y cultural de la Nación; defender la independencia nacional, mantener la integridad territorial y asegurar la convivencia pacífica y la vigencia de un orden justo.

${ }^{14}$ El debido proceso se aplicará a toda clase de actuaciones judiciales y administrativas. Nadie podrá ser juzgado sino conforme a leyes preexistentes al acto que se le imputa, ante juez o tribunal competente y con observancia de la plenitud de las formas propias de cada juicio. En materia penal, la ley permisiva o favorable, aun cuando sea posterior, se aplicará de preferencia a la restrictiva o desfavorable. Toda persona se presume inocente mientras no se la haya declarado judicialmente culpable. Quien sea sindicado tiene derecho a la defensa y a la asistencia de un abogado escogido por él, o de oficio, durante la investigación y el juzgamiento; a un debido proceso público sin dilaciones injustificadas; a presentar pruebas y a controvertir las que se alleguen en su contra; a impugnar la sentencia condenatoria, y a no ser juzgado dos veces por el mismo hecho. Es nula, de pleno derecho, la prueba obtenida con violación del debido proceso.

${ }^{15}$ Los tratados y convenios internacionales ratificados por el Congreso, que reconocen los Derechos Humanos y que prohíben su limitación en los estados de excepción, prevalecen en el orden interno. Los derechos y deberes consagrados en esta Carta, se interpretarán de conformidad con los tratados internacionales sobre Derechos Humanos ratificados por Colombia. Adicionado por el Acto Legislativo 02 de 2001, con el siguiente texto: El Estado Colombiano puede reconocer la jurisdicción de la Corte Penal Internacional en los términos previstos en el Estatuto de Roma adoptado el 17 de julio de 1998 por la Conferencia de Plenipotenciarios de las Naciones Unidas y, consecuentemente, ratificar este tratado de conformidad con el procedimiento establecido en esta Constitución. La admisión de un tratamiento diferente en materias sustanciales por parte del Estatuto de Roma con respecto a las garantías contenidas en la Constitución tendrá efectos exclusivamente dentro del ámbito de la materia regulada en él.

${ }^{16}$ Se garantiza el derecho de toda persona para acceder a la administración de justicia. La ley indicará en qué casos podrá hacerlo sin la representación de abogado.

${ }^{17}$ Modificado por el art. 2, Acto Legislativo No. 03 de 2002. El nuevo texto es el siguiente: La Fiscalía General de la Nación está obligada a adelantar el ejercicio de la acción penal y realizar la investigación de los hechos que revistan las características de un delito que lleguen a su conocimiento por medio de denuncia, petición especial, querella o de oficio, siempre y cuando medien suficientes motivos y circunstancias fácticas que indiquen la posible existencia del mismo. No podrá, en consecuencia, suspender, interrumpir, ni renunciar a la persecución penal, salvo en los casos que establezca la ley para la aplicación del principio de oportunidad regulado dentro del marco de la política criminal del Estado, el cual estará sometido al control de legalidad por parte del juez que ejerza las funciones de control de garantías. Se exceptúan los delitos cometidos por Miembros de la Fuerza Pública en servicio activo y en relación con el mismo servicio. En ejercicio de sus funciones la Fiscalía General de la Nación, deberá: 6. Solicitar ante el juez de conocimiento las medidas judiciales necesarias para la asistencia a las víctimas, lo mismo que disponer el restablecimiento del derecho y la reparación integral a los afectados con el delito; (...) 7. Velar por la protección de las víctimas,
} 
En este orden de ideas, a juicio de la Sala, se debe adoptar una visión amplia e integral que informe los derechos de las víctimas a la reparación y a la restitución, y su conexión intrínseca con los derechos a la verdad y a la justicia. Así mismo, esta Corporación recaba en que los derechos fundamentales a la verdad, a la justicia, a la reparación y a la restitución como parte de ésta última, en virtud de las violaciones masivas y sistemáticas de Derechos Humanos en el marco del conflicto armado, dan lugar a una serie de obligaciones inderogables a cargo del Estado, como la de prevenir estas violaciones, y una vez ocurridas éstas, la obligación de esclarecer la verdad de lo sucedido, la investigación y sanción de este delito sistemático y masivo en contra de la población civil, y la reparación integral a las víctimas, cuyo componente preferente y principal es la restitución, tanto por la vía judicial-penal y contencioso-administrativa, como por la vía administrativa, así como el deber de garantizar y facilitar el acceso efectivo de las víctimas a estas diferentes vías (Corte Constitucional, 2012).

La Corte indica que el derecho a la verdad en Colombia es un derecho humano integrado al ordenamiento jurídico a través del bloque de constitucionalidad, que debe ser tratado internamente a partir de la normatividad nacional como derecho fundamental propio de las víctimas. Esto demuestra que tiene doble connotación, porque, además de ser un derecho humano, se constituye en un derecho fundamental debido a la existencia de un conflicto armado interno.

Lo anterior se refuerza cuando, en los términos de Alexy, se entiende que los derechos fundamentales son derechos del individuo, extensibles a ciertos grupos, organizaciones y

los jurados, los testigos y demás intervinientes en el proceso penal, la ley fijará los términos en que podrán intervenir las víctimas en el proceso penal y los mecanismos de justicia restaurativa. 
personas jurídicas, los cuales favorecen los intereses individuales y colectivos, y deben tener una correlación con los Derechos Humanos (Alexy, 2003, págs. 21-31). En ese sentido, el Estado colombiano tiene el imperativo de buscar la verdad como derecho que está bajo su tutela, de manera tal que los perpetradores de graves violaciones a los Derechos Humanos en el marco de justicia transicional tienen la obligación de aportar verdad plena sobre las conductas punibles ejecutadas para, a partir de ella, ser elegibles a las sanciones propias previstas en el ámbito de la Jurisdicción Especial para la Paz y acceder a los beneficios previstos en la Ley 1820 de 2016, estatuto que regula la amnistía, el indulto y los tratamientos penales especiales y otras disposiciones (Naqvi, 2006, p. 3).

Por estas razones, la garantía a la verdad y demás derechos de las víctimas se convierten en una obligación de las partes que suscribieron el Acuerdo Final que tiene como propósito central la terminación del conflicto armado, porque los derechos de las víctimas son derechos asistenciales que deben ser atendidos en el marco de una política social de bienestar (Mardones $\&$ Mate, 2003). De manera que, en el marco de la política planteada por el Gobierno Nacional y las FARC-EP, es imperativo que su implementación cumpla con los parámetros establecidos y atienda las necesidades que surjan para brindar una protección plena a las víctimas.

\section{EL DERECHO A LA VERDAD EN EL ACUERDO FINAL PARA LA PAZ: MECANISMO DE PROTECCIÓN Y GARANTÍAS DEL DERECHO A LA VERDAD EN LA IMPLEMENTACIÓN}

\subsection{Mecanismo de garantía del derecho a la verdad en el Acuerdo Final}

El Acuerdo Final para la Terminación del Conflicto y la Construcción de una Paz Estable y Duradera (2016) suscrito entre el Gobierno Nacional y las FARC-EP, tiene como objetivo 
principal llegar al fin del conflicto armado y construir una paz estable y duradera. El punto 5 del referido documento incluyó expresamente la protección de los Derechos Humanos de las víctimas, en aras de conseguir una plena satisfacción de las necesidades de quienes han sido afectados por el conflicto armado y en especial el derecho a la verdad.

Para lo anterior, resultó neurálgico en el proceso de implementación del pacto de paz el esclarecimiento de la verdad, porque es un compromiso inequívoco de las partes contratantes establecer y esclarecer lo sucedido a lo largo de varias décadas de conflicto armado interno, con el fin de determinar sus causas, orígenes y efectos, como elemento esencial que asegure la protección de los derechos a las víctimas, teniendo como objetivo principal la reconstrucción de la confianza hacia el Estado colombiano y la promoción de la convivencia pacífica.

Por esas razones, el Sistema Integral de Verdad, Justicia, Reparación y No Repetición (SIVJRNR), con la creación de la Comisión de la Verdad, la Convivencia y la No Repetición, busca contribuir al esclarecimiento de las violaciones e infracciones y ofrecer una explicación amplia a toda la sociedad de la complejidad del conflicto, a través de la aceptación de responsabilidad de quienes participaron en la ejecución de conductas delictivas que llevaron a la vulneración de los Derechos Humanos e infringieron el Derecho Internacional Humanitario.

De igual manera, el Acuerdo Final para la Paz (2016) crea la base de justicia con el fin de luchar contra la impunidad, estableciendo mecanismos judiciales que contribuyan a la búsqueda de la verdad. De manera que, a partir de la creación de la Jurisdicción Especial para la Paz, como centro de la justicia transicional, se establecen los derroteros mediante los cuales también se busca la verdad de lo ocurrido durante el conflicto; se crean instancias judiciales como la Sala de Reconocimiento de la Verdad y Responsabilidad y la Sala de Amnistías o Indultos, a través de 
las cuales se dan garantías reales al cumplimiento de la reparación integral a las víctimas y a los convenios internacionales (Gobierno Nacional-FARC-EP, 2016).

También, tenemos la Comisión para el Esclarecimiento de la Verdad, la Convivencia y la No Repetición y la Unidad de Búsqueda de Personas Dadas por Desaparecidas, que son creadas como organismos no judiciales, donde todas las partes del conflicto armado van a poder, por un lado, acercarse a contar la verdad de lo ocurrido en la guerra y, por otro lado, observar la implementación de medidas para la búsqueda de la verdad y de la reconstrucción de la historia del conflicto interno (Gobierno Nacional-FARC-EP, 2016). Son, en sí, organismos no judiciales que están destinados de manera exclusiva a la consecución de la verdad para garantizar el derecho de las víctimas a conocer lo ocurrido.

Lo anterior, con el fin de establecer el marco de justicia transicional en el que se enmarca el Acuerdo; en el entendido de que los procesos que determina, constituyen el medio que permitirá llegar a las transformaciones necesarias del orden social y político por la finalización de un conflicto interno y la consiguiente consecuencia de la paz (Uprimny Yepes, 2006, p. 19).

Es por eso que, en consideración de este tratado, el derecho a la verdad es una necesidad de la sociedad para construir sobre los cimientos de la verdad, que son los únicos que pueden soportar la construcción de una sociedad pacífica, pues es la verdad la única herramienta con la que puede cerrarse el capítulo de la historia de la violencia en Colombia y que, conjunto con la garantía de los demás derechos de las víctimas es la forma de llegar a la paz, como fin último del Acuerdo Final para la Paz. 


\subsection{Garantías del derecho a la verdad de las víctimas en la implementación del Acuerdo final}

La Corte Constitucional mediante Sentencia C-579 (2013), se pronunció sobre la constitucionalidad del Acto Legislativo 01 (Congreso de la República de Colombia, 2012), mediante el cual se establecieron instrumentos jurídicos de justicia transicional en el marco del Artículo 22 de la Constitución Política de 1991, haciendo una revisión exhaustiva de la constitucionalidad de los actos reformatorios de la Constitución. Esto por cuanto el Acto Legislativo 01 de 2012 fijó instrumentos jurídicos de justicia transicional para facilitar la terminación del conflicto armado y lograr una paz estable y duradera, "con garantías de no repetición y de seguridad para todos los colombianos; y (garantizar) en el mayor nivel posible, los derechos de las víctimas a la verdad, la justicia y la reparación" (Congreso de la República de Colombia, 2012).

Estableció la Corte que la Constitución defiende el Estado social, democrático y de derecho, razón por la que uno de los pilares fundamentales es el de respetar, proteger y garantizar los derechos de la sociedad y en especial los de las víctimas con el propósito de prevenir su vulneración, tutelarlos de manera efectiva, garantizar la reparación y la verdad, evitar la impunidad mediante la investigación, juzgamiento y sanción de las graves violaciones a los Derechos Humanos y al Derecho Internacional Humanitario. En ese sentido, el Tribunal Constitucional expresamente reseña:

El pilar esencial que impone al Estado el deber de respetar, proteger y garantizar los derechos de la sociedad y de las víctimas, exige que todas ellas tengan, como mínimo, las siguientes garantías: (i) transparencia del proceso de selección y priorización; (ii) una 
investigación seria, imparcial, efectiva, cumplida en un plazo razonable y con su participación; (iii) la existencia de un recurso para impugnar la decisión sobre la selección y priorización de su caso; (iv) asesoría especializada; (v) el derecho a la verdad, de modo que cuando un caso no haya sido seleccionado o priorizado, se garantice a través mecanismos judiciales no penales y extrajudiciales; (vi) el derecho a la reparación integral y; (vii) el derecho a conocer dónde se encuentran los restos de sus familiares. Para que sea aplicable el Marco Jurídico para la Paz es necesario exigir la terminación del conflicto armado respecto del grupo desmovilizado colectivamente, la entrega de las armas y la no comisión de nuevos delitos en los casos de desmovilización individual.

$(\ldots)$

El Acto Legislativo 01 de 2012, se justifica como una ponderación entre la reconciliación y la justicia, por ello es necesario que los grupos armados no solamente se comprometan a la terminación del conflicto, sino también a contribuir a la satisfacción de los derechos de las víctimas, pues de lo contrario no expresarán una voluntad seria con el restablecimiento de sus derechos. Por lo anterior, para que procedan los criterios de selección y priorización, el Estado debe exigir al grupo armado al margen de la ley una contribución efectiva y real al esclarecimiento de la verdad y a la reparación de las víctimas, la liberación de todos los secuestrados y la desvinculación de todos los menores de edad que se encuentren en poder de los grupos armados al margen de la ley.

6. Obligación de revelación de todos los hechos constitutivos de graves violaciones a los Derechos Humanos y al Derecho Internacional Humanitario. Uno de los componentes esenciales de la administración de justicia es el derecho a la verdad, el cual no solamente 
tiene un elemento individual, sino también uno colectivo, como derecho de toda la sociedad a conocer lo sucedido en el conflicto armado, con el objeto de remediar las causas de la confrontación.

7. Dentro del diseño integral de los instrumentos de justicia transicional derivados del marco jurídico para la paz, la Ley Estatutaria deberá determinar los criterios de selección y priorización, sin perjuicio de la competencia que la propia Constitución atribuye a la Fiscalía para fijar, en desarrollo de la política criminal del Estado, los criterios de priorización.

8. El articulado de la Ley Estatutaria deberá ser respetuoso de los compromisos internacionales contemplados en los tratados que hacen parte del bloque de constitucionalidad, en cuanto a la obligación de investigar, juzgar y en su caso sancionar las graves violaciones a los Derechos Humanos y al Derecho Internacional Humanitario.

9. El mecanismo de suspensión total de ejecución de la pena, no puede operar para los condenados como máximos responsables de los delitos de lesa humanidad, genocidio y crímenes de guerra cometidos de manera sistemática. (Corte Constitucional, 2013)

Igualmente, la Corte en Sentencia 669 de 2016, concluyó, después de recordar el contenido de las sentencias C-379 de 2016, C-577 de 2014, C-771 de 2011 y C-370 de 2006, lo siguiente:

(i) La paz es uno de los fines esenciales del modelo de Estado adoptado en la Carta Política de 1991, pero no es un valor absoluto; (ii) la búsqueda de la paz permite adoptar medidas que provocan fuertes tensiones con otros principios y derechos de raigambre 
superior; (iii) el juez constitucional debe determinar los límites a las medidas adoptadas para el logro de la paz frente a las tensiones que generan y hacerlos respetar; (iv) en esa medida la jurisprudencia constitucional ha señalado algunos límites no taxativos de los procesos dirigidos a la consecución de la paz, tales como los derechos de las víctimas a la justicia, la verdad y la reparación, el núcleo básico del derecho al debido proceso y la imprescriptibilidad de la acción penal respecto de ciertos delitos, y (v) los procesos de justicia transicional deben propender por objetivos estructurales que van más allá de la sola terminación del conflicto, por ejemplo el fortalecimiento del Estado Social de Derecho y de la democracia. (Corte Constitucional, 2016)

De esa manera, el condicionamiento que impone el Acto Legislativo 01 de 2012, según la interpretación que realiza la Corte Constitucional, propende por garantizar la reparación de las víctimas, sobre todo en lo que se refiere al derecho a la verdad, punto prioritario que conduce a institucionalizar medidas específicas y condicionamientos autónomos para la garantía del derecho fundamental a la verdad.

En ese sentido, se observa que el Acuerdo Final (2016) establece las medidas e instrumentos dirigidos a garantizar la prevalencia de los derechos de las víctimas a la Verdad, Justicia, Reparación y No Repetición, autorizando como contraprestación a favor de los perpetradores unas sanciones acordes con un régimen de transición, de donde se explica y justifica que la implementación del acuerdo de paz prevea la creación de (i) la Comisión para el Esclarecimiento de la Verdad, la Convivencia y la No Repetición, (ii) la Unidad de Búsqueda de Personas Dadas por Desaparecidas en el Contexto y en Razón del Conflicto Armado, (iii) la Jurisdicción Especial para la Paz y (iv) las medidas de reparación integral para la Construcción de paz y las garantías de no repetición. 
Con el fin de garantizar la implementación del Acuerdo Final, asegurar su cumplimiento y obtener el fin del conflicto armado interno, mediante Acto Legislativo 01 (2016), se crea de manera excepcional y transitoria un Procedimiento Legislativo Especial para la Paz, denominado fast track, a fin de agilizar los trámites normativos especiales de implementación de dicho acuerdo, hasta el punto de considerarse, en el Acto Legislativo, que el Acuerdo Final tiene una eficacia normativa directa que debe ser aplicado a nivel institucional y marcar el punto de referencia para las decisiones que se tomen con posterioridad a su entrada en vigencia.

Por lo tanto, el Acuerdo Final deberá ser tenido en cuenta durante el periodo de implementación como parámetro de interpretación y referente de desarrollo y validez de las normas y las leyes de implementación (Congreso de la República de Colombia, 2016); de manera que si uno de los puntos decisivos es la garantía del derecho a la verdad de las víctimas, las normas expedidas con el fin de implementar dicho Acuerdo Final deberán propender por garantizar la verdad plena sobre los hechos delictivos ocurridos con ocasión o por razón del conflicto armado interno.

En el mismo sentido, se pronunciaron durante la audiencia pública celebrada en la Comisión Primera del Senado del Congreso en la República el 25 de enero de 2017, algunos doctrinantes y conocedores del derecho constitucional colombiano, durante el trámite del Acto Legislativo 1 de 2016 Senado, oportunidad en la que varios expertos expresaron sus opiniones, entre las que vale la pena destacar ${ }^{18}$ :

\footnotetext{
18 «Informe de Ponencia para Primer Debate al Proyecto de Acto Legislativo 01 de 2016 Senado, por medio del cual se adiciona un artículo transitorio a la Constitución con el propósito de dar estabilidad y seguridad jurídica al Acuerdo Final para la Terminación del Conflicto y la Construcción de una Paz Estable y Duradera. Procedimiento Legislativo Especial», en Gaceta del Congreso 52. Bogotá, 6 de febrero de 2017.
} 
(i). Rodrigo Uprimny dijo que el Acuerdo Final tiene valor jurídico para salvaguardar la implementación del proceso de paz, que es el propósito del Acto Legislativo; sin embargo, no hace parte del bloque de constitucionalidad, pero sí sirve de parámetro para su interpretación en temas de DIH y derechos fundamentales. Finalmente, expresó que las autoridades podrán usar el acuerdo como criterio de interpretación (Uprimny, 2017).

(ii). Alejandro Ramelli explicó que es un Acuerdo especial, documento político y a la vez un acto jurídico unilateral del Presidente de la República (Ramelli, 2017).

(iii). Gustavo Zafra consideró que el Acuerdo Final debe ser interpretado según dos principios: la buena fe y el pacta sunt servanda. Estos principios de ius cogens permiten anclar el acuerdo de paz a la buena fe (Zafra, 2017).

(iv). Ricardo Abello señaló que se trata de unos acuerdos con doble característica: componente político y jurídico, siendo necesario incluir lo jurídico para poder cumplir con lo político (Bello, 2017).

(v). Giovanni Ortegón enfatizó que la paz es un principio constitucional y un derecho colectivo y subjetivo, de modo que al incorporarla al sistema normativo guía la actuación de todas las autoridades estatales; lo establecido debe ser la regla que sujete todos los procesos de reglamentación (Ejecutivo y Legislativo) y debe ser un principio de interpretación judicial constitucional (Ortegón, 2017).

(vi). Édgar Valdeleón manifestó que de la estructura del Acuerdo Final hermenéuticamente se infiere que es una decisión política (Valdeleón, 2017). Y, 
(vii). Francisco Barbosa consideró que el Acuerdo de la Habana es un acuerdo especial a la luz del DIH. Esto significa que las normas humanitarias son de obligatorio cumplimiento porque son consuetudinarias (Barbosa, 2017).

Entonces, se puede observar que los diferentes desarrollos normativos, jurisprudenciales y doctrinales atienden a los presupuestos de garantizar el derecho a la verdad de las víctimas como se planteó en el Acuerdo, tratando a este como un componente base para la interpretación y aplicación de las normas, puesto que, finalmente, lo que se pretende es establecer la paz en la sociedad colombiana, fin que en un estado excepcional de justicia solo se puede conseguir con la reparación de la víctimas del conflicto a partir de los planteamiento del Acuerdo.

Una muestra de las garantías que contiene la implementación para el derecho a la verdad es la Ley 1820 de 2016, mediante la cual se dictan disposiciones sobre amnistía, indulto y tratamientos penales especiales, que en el catálogo de principios que rigen su aplicación destaca que la interpretación de dicha ley debe atender los principios de integralidad y contribución a la satisfacción de los derechos de las víctimas, Artículos 6 y 14, que disponen lo siguiente:

Artículo $6^{\circ}$. Integralidad. Las amnistías e indultos, y los tratamientos penales especiales, incluidos los diferenciados para agentes del Estado, son medidas del Sistema Integral de Verdad, Justicia, Reparación y No Repetición, cuyos fines esenciales son facilitar la terminación del conflicto armado interno, contribuir al logro de la paz estable y duradera con garantías de no repetición, adoptar decisiones que otorguen plena seguridad jurídica para todos y satisfacer los derechos de las víctimas. Por ello, los distintos componentes y medidas del Sistema Integral están interconectados a través de mecanismos, garantías, requisitos para acceder y mantener los tratamientos especiales de justicia en la 
Jurisdicción Especial para la Paz. Se aplicará la totalidad de los principios contenidos en el acuerdo de creación de la Jurisdicción Especial para la Paz respecto de la amnistía, el indulto y otros mecanismos especiales de extinción de responsabilidades y sanciones penales principales y accesorias. Lo anterior se aplicará del mismo modo respecto de todas las sanciones administrativas o renuncia del Estado a la persecución penal. Los principios deberán ser aplicados de manera oportuna.

Artículo 14. Contribución a la satisfacción de los derechos de las víctimas. La concesión de amnistías o indultos o de cualquier tratamiento especial, simétrico, simultáneo, equilibrado y equitativo no exime del deber de contribuir individual o colectivamente al esclarecimiento de la verdad o del cumplimiento de las obligaciones de reparación que sean impuestas por la Jurisdicción Especial para la Paz. Si durante los cinco años siguientes a la concesión de la amnistía, indulto o de cualquier tratamiento especial, simétrico, simultáneo, equilibrado y equitativo, se rehusaran de manera reiterada e injustificada a cumplir los requerimientos del Tribunal para la Paz de participar en los programas de contribución a la reparación de las víctimas, o acudir ante la Comisión de Esclarecimiento de la Verdad de la Convivencia y No Repetición, o ante la Unidad de Búsqueda de las Personas Dadas por Desaparecidas cuando exista obligación de comparecer ante las anteriores, perderán el derecho a que se les apliquen las sanciones propias de la Jurisdicción Especial para la Paz o equivalentes previstas en cualquier tratamiento de los definidos como especial, simultáneo, equilibrado y equitativo, en el evento de que llegaran a ser declarados responsables por algunas de las conductas que se atribuyan al interior de la misma. (Congreso de la República de Colombia, 2016) 
En el mismo sentido, se observa el contenido del Decreto 277 de 2017, expedido por la Presidencia de la República, mediante el cual se estableció el procedimiento para la efectiva implementación de la Ley 1820 de 2016, estatuto en el que se destaca que los principios aplicables para su implementación e interpretación son los establecidos en la ley que la reglamenta (Presidencia de la República, 2017).

También ha de subrayarse que el Acto Legislativo 01 de 2017, mediante el cual se crea un título de disposiciones transitorias de la Constitución para la terminación del conflicto armado y la construcción de una paz estable y duradera, cumple con los referentes del Acuerdo Final, porque en su Artículo 1, por ejemplo, establece como asunto núcleo de la implementación la creación de los mecanismos y medidas que ya se indicaron, debiéndose aquí reiterar la importancia que reviste la creación de la Comisión para el Esclarecimiento de la Verdad, la Convivencia y la No Repetición, con la que se busca hacer un especial énfasis en las medidas restaurativas y reparadoras. Así mismo, el Artículo 2, que desarrolla como finalidad de dicha comisión la búsqueda de la verdad de lo ocurrido en el marco del conflicto armado y la contribución al esclarecimiento de las violaciones e infracciones cometidos en el mismo, además de ofrecer una explicación amplia de su complejidad a toda la sociedad (Congreso de la República de Colombia, 2017).

Por su parte, el Acto Legislativo 02 de 2017 resaltó que las autoridades del Estado tienen la obligación de cumplir de buena fe con lo establecido en el Acuerdo Final, por lo que sus actuaciones, los desarrollos normativos sobre el "Acuerdo Final y su interpretación y aplicación deberán guardar coherencia e integralidad con lo acordado, preservando los contenidos, los compromisos, el espiritu y los principios del Acuerdo Final" (Congreso de la República de Colombia, 2017). 
Igualmente, con especial referencia, en el Decreto 588 del 5 de abril de 2017, mediante el cual se organiza la Comisión para el Esclarecimiento de la Verdad, la Convivencia y la No Repetición, que se caracteriza como entidad de rango constitucional, a la que se le asignan como objetivos, en resumen: contribuir al esclarecimiento de lo ocurrido (para lo cual se privilegia la obtención de verdad plena), suscitar y contribuir el reconocimiento y promover la convivencia en los territorios (Congreso de la República de Colombia, 2017).

Todo lo expuesto permite observar que las partes que suscribieron el Acuerdo Final para la Paz, que las instituciones propuestas y las disposiciones que establecen beneficios para los grupos al margen de la ley o a favor de todos aquellos que hayan colaborado con su causa, deberán estar limitados siempre por los derechos de las víctimas y, sobre todo, por el derecho a la verdad como condición para el otorgamiento de dichas prerrogativas y, adicionalmente, el mantenimiento de dichos beneficios, hasta el punto de poner limitaciones y obligaciones; de modo que la obtención de la verdad justifica todo el sistema jurídico transicional creado.

Se colige de lo expuesto que el Estado colombiano debe buscar la verdad como derecho que está bajo su tutela, de manera que en el marco de justicia transicional propenda por alcanzar la verdad, derecho que a su turno justifica que las amnistías e indultos que se concedan a los insurgentes, por cuanto conocer la realidad de lo ocurrido, satisface los derechos de las víctimas. Para tal fin, se crean instituciones que deben seguir los lineamientos del acuerdo en la búsqueda de la verdad, surgiendo así una extraordinaria justificación de instituciones transicionales como la Comisión para el Esclarecimiento de la Verdad, la Convivencia y la No Repetición, la Unidad de Búsqueda de Personas Dadas por Desaparecidas en el Contexto y en Razón del Conflicto Armado, la Jurisdicción Especial para la Paz y las medidas de reparación integral para la Construcción de Paz y las garantías de No Repetición. 
Solo cumpliendo con lo establecido en el Acuerdo Final se satisfacen las garantías para el esclarecimiento de la verdad y se tutelan los derechos de las víctimas, porque con las nuevas instituciones los beneficios para los miembros de los grupos al margen de la ley, o a favor de todos aquellos que hayan colaborado con su causa, deberán estar limitados siempre en la garantía de los derechos de las víctimas y, sobre todo, del derecho a la verdad, que derivan en condición para el otorgamiento de dichas prerrogativas y de su mantenimiento hacia el futuro, hasta el punto de poner limitaciones y obligaciones de aportar verdad plena.

Los argumentos que sustentan las garantías del derecho a la verdad en el Acuerdo y las normas creadas toman fortaleza bajo uno de los últimos pronunciamientos de la Corte Constitucional, la cual, en sentencia de marzo de 2018, consideró que el derecho a la verdad tiene doble connotación, porque protege a la comunidad en su colectividad; es decir, a todos los colombianos y, en su individualidad, a las víctimas directas del conflicto (Corte Constitucional, Sentencia C-007, 2018).

La Corte también señaló que sobre la garantía de la protección del derecho a la verdad se deben tener dos componentes: el primero, (ii) sobre el deber del Estado en la adopción de diseños institucionales que permitan la efectividad de este derecho de manera idónea, participativa y completa, evitando obstáculos jurídicos o de hecho. La Corte Interamericana ha expresado que la verdad contribuye a la reparación, a través del proceso penal, de manera importante, pero también de medios extrajudiciales, tales como las comisiones de la verdad, en razón a que contribuyen a la construcción y preservación de la memoria, el esclarecimiento de los hechos y la determinación de responsabilidades institucionales, sociales y políticas; y, la segunda, sobre (ii) el deber de investigar, juzgar y sancionar a los responsables de las violaciones a los derechos humanos. Es importante añadir que, en casos de desaparición forzada, el derecho a 
la verdad implica conocer el paradero del desaparecido (Corte Constitucional, Sentencia C-007, 2018).

Lo expresado, constituye la conclusión de los silogismos planteados hasta el momento en este trabajo: solo con la creación de mecanismos e instituciones judiciales y no judiciales se garantiza el derecho a la verdad, debido a que "mientras subsista el silencio sobre lo sucedido, mientras no se encuentre la verdad, la posibilidad de creer que se ha cerrado un ciclo de violencia es nula, el conflicto continúa hasta que se sabe la verdad tanto judicial como histórica" (Fajardo Arturo, 2012, p. 16).

A continuación, se abordarán los conceptos, características, similitudes y diferencias de la amnistía y el indulto, se expondrá lo establecido en esa materia por parte del Acuerdo Final para la Paz y se hará un análisis jurisprudencial sobre el desarrollo dado por el Congreso Nacional y el Gobierno.

\section{CAPÍTULO SEGUNDO}

\section{LA AMNISTÍA Y EL INDULTO: ALIVIOS PENALES DEL ACUERDO DE PAZ}

\section{BREVE RESEÑA HISTÓRICA SOBRE LA AMNISTÍA Y EL INDULTO}

En la antigüedad, conceder una clemencia era un ejercicio de las facultades del rey, quien de conformidad con el derecho divino y natural tenía la suprema potestad "de perdonar a los delincuentes, del mismo modo que la tiene Dios para perdonar los pecados" (Enciclopedia Jurídica Omeba, 1961, p. 591). De los primeros informes que se obtuvieron sobre la amnistía y el indulto se encuentra la Ley de Olvido de Trasíbulo (440 a.C. - 388 a.C.), después de liberar a 
Atenas de los Treinta Tiranos, que se trató de una amnistía concedida por delitos políticos (Enciclopedia Jurídica Omeba, 1961, p. 591).

En Roma, también se crearon ese tipo de alivios, "en los casos de conmociones interiores y de guerras civiles, se concedian también exenciones excepcionales de persecución penal" (Monmsen, 1976, pag. 290). También se creó “la sulpicia, provocada por las condenas por delitos políticos relativos a la guerra social” (Manzini, 1950, p. 27). En tiempos del Imperio, cuando se concentró más el poder, apareció lo que se conoció con el nombre de Indulgentia Principis o indulgencia del príncipe, que contenía la amnistía (abolitio generalis publica), el indulto (poenae gratian facit generalis, comunis) y la gracia (poena gratian facit specialis).

En el período feudal y el nacimiento de los burgos, se fraccionó el poder y aparecieron muchas autoridades facultadas para conceder gracias que, en términos generales, permitieron ser identificadas como la amnistía y el indulto. En sentido estricto fue creada, desarrollada y aplicada en los Estados monárquicos y feudales (Poveda Perdomo, 1984, p. 44).

Posteriormente, con las revoluciones burguesas que traían consigo las luchas por los derechos y libertades, se dio el momento de la consagración en textos legales de las diferentes formas de ius gratiandi o derecho de perdonar, de tal forma que en muchos casos las constituciones o normas establecidas en la antigüedad dedicaban específicos preceptos a la amnistía y el indulto (Poveda Perdomo, 1984).

\section{LA AMNISTÍA Y EL INDULTO EN COLOMBIA}

La amnistía, como institución jurídica, apareció en la Constitución de 1886 (Asamblea Nacional Constituyente, 1886), Artículo 30, mediante el cual se dispuso que "no habrá pena de 
muerte por delitos políticos. La ley los definirá”. Así mismo, el Artículo 76 de dicha disposición, autorizó al Congreso a conceder por la mayoría equivalente a dos terceras partes de votos en cada una de las Cámaras, "por graves motivos de conveniencia pública, amnistías o indultos generales por delitos políticos. En el caso de que los favorecidos queden eximidos de la responsabilidad civil respecto de particulares, el Gobierno estará obligado a las indemnizaciones a que hubiere lugar" (Asamblea Nacional Constituyente, 1886).

En general, la amnistía y el indulto han sido utilizadas en la historia de Colombia como mecanismo de reconciliación y para poner fin a un conflicto. Es más, hasta 1982 se habían concedido en Colombia alrededor de 67 indultos y amnistías a pesar de los saltos constitucionales del siglo XIX (Cesar, 1982, p. 6A). En la Constitución de Cundinamarca de 1811 (Palacio del Poder Ejecutivo, 1811) y en la Constitución de la Provincia de Antioquia de 1815 (Colegio Revisor Constituyente y Electoral, 1815), se estableció el indulto general que podía conceder el Poder Ejecutivo, en los casos de conflicto social o conveniencia para la Provincia (Uribe Vargas, 1977, págs. 323, 557 y 657).

En los gobiernos de Virgilio Barco y César Gaviria, resaltado ut supra, fueron varias las amnistías e indultos decretados a favor de los miembros de organizaciones alzadas en armas, por intermedio de lo dispuesto en la Ley 35 de 1982, conforme la cual se otorgó amnistía general a los autores, cómplices o encubridores de delitos políticos cometidos antes de la vigencia de la referida ley; así mismo, gracias a la Ley 77 de 1989, ratificada por la Ley 7 de 1992, fueron indultados los guerrilleros del Movimiento M19.

En el mismo sentido, la denominada Ley de Orden Público, Ley 418 de 1997 (Congreso de Colombia, 1997), por la cual se consagran unos instrumentos para la búsqueda de la 
convivencia, la eficacia de la justicia y se dictan otras disposiciones, vigente desde el 26 de diciembre de 1997, reguló varias "causales de extinción de la acción y de la pena en casos de delitos políticos", especialmente en su título III, con la finalidad de resolver la situación jurídica de los desmovilizados de los grupos al margen de la ley que enfrenten cargos por ese tipo delictual.

La original Ley 418 de 1997 fue prorrogada y posteriormente modificada por las Leyes 548 de 1999, 782 de 2002, 1106 de 2006, 1421 de 2010, 1738 de 2014 y 1779 de 2016, lo que significa que durante 20 años se han venido concediendo amnistías e indultos a integrantes de diversos aparatos organizados de poder al margen de la ley.

El Artículo 50 regula el indulto y el artículo 60 la amnistía, Ley 418 (Congreso de Colombia, 1997), bajo las denominaciones de cesación de procedimiento, la resolución de preclusión de la instrucción o la resolución inhibitoria, de acuerdo con el estado del respectivo proceso penal. La jurisprudencia de la Corte Suprema de Justicia acepta que dichas modalidades de extinción de la acción penal o de la pena son formas concretas de amnistía, como lo precisa el Informe de ponencia para primer debate del proyecto de Ley 202 de 2010, Senado, y 149 de 2010, Cámara (Congreso de la República de Colombia, 2010).

Se ha considerado que las diferentes modalidades de amnistía e indulto previstas en la Ley de Orden Público, prevén tres escenarios:

Uno ofrecido a los guerrilleros que sólo deban responder de los delitos políticos y conexos; otro, creado para los desmovilizados rasos de los grupos paramilitares, que sólo cometieron infracciones calificadas como menores; y otro, más amplio, dirigido a los combatientes de todos los bandos, que perpetraron toda clase de punibles y que 
manifestaron su decisión voluntaria y sincera de cesar su accionar armado y cumplir con las exigencias previstas en la legislación a la que se acogen. (Corte Suprema de Justicia, Sala de Casación Penal, 2011)

Es evidente, de conformidad con lo reseñado, que a través de la historia de Colombia se han presentado diversas situaciones conflictivas donde se han tenido que proponer mecanismos políticos para poder resolver dichas controversias, por lo que se han tenido que establecer normas con propósitos de reconciliación que han sido denominadas amnistía e indulto.

\section{AMNiSTÍA E INDULTO: CONCEPTO, CARACTERÍSTICAS, DIFERENCIAS Y SIMILITUDES}

\subsection{Intentos de la doctrina por definir las instituciones amnistía e indulto}

La doctrina enseña que "en el derecho intermedio no se encuentra una neta distinción entre amnistía, indulto y gracia, sino que, casi siempre, los tres institutos son confundidos entre si”" (Manzini, 1950, p. 29). Sin embargo, en consideración de otros autores, la amnistía y el indulto son instituciones jurídicas que tienen un profundo contenido político y que presentan una gran cantidad de semejanzas; empero, jurídicamente se puede establecer que son ostensiblemente diferentes, así estén dirigidas a un mismo propósito (Poveda Perdomo, 1984, págs. 43-51).

Se ha establecido que la amnistía es la institución que se fundamenta en la justicia y en la conveniencia social, que tienen la única finalidad de suavizar los rigores que resulten de la aplicación de las leyes en extremo severas; tomar en consideración algunas circunstancias que no se hayan revelado hasta el momento de la ejecución de la pena, para que se utilicen como método para suavizar las penas; reparar, aun cuando no sea completamente, las consecuencias de los 
errores judiciales, y armonizar la eficacia de la justicia con los intereses y funciones del Estado (Zuñiga Urbina, 1997, 371-422). Por otro lado, el indulto es una figura jurídica de connotación política que puede otorgarse por normas jurídicas, con el fin de anular la pena, total o parcialmente, por delitos políticos o conexos a ellos (Poveda Perdomo, 1984, p. 46).

Ahora bien, sobre la facultad de amnistiar, indultar o conceder otras prerrogativas a quienes hayan cometido crímenes de lesa humanidad o que hayan vulnerado gravemente los Derechos Humanos o el Derecho Internacional Humanitario, se han establecido algunos límites derivados del propio Derecho Internacional Humanitario, pues, en períodos de transición, no se pueden simplemente anular las obligaciones internacionales del Estado, como lo ha señalado la Comisión Interamericana, lo que resulta prudente es "compatibilizar el recurso a la concesión de amnistías e indultos a favor de personas que se han alzado en armas contra el Estado, con la obligación de éste de esclarecer, castigar y reparar a las víctimas del conflicto armado” (Botero Marino \& Restrepo Saldarriaga, 2006, págs. 53-55).

\subsection{Características semejanzas y diferencias entre la amnistía y el indulto}

De las ideas desarrolladas en los títulos anteriores sobre las instituciones amnistía e indulto, se encuentra que son alivios punitivos que encuentran su validación en casos de extrema necesidad donde el Estado busca cumplir con uno de sus fines. Han sido la creación insignia de la justicia transicional para otorgar a los perpetradores alivios penales.

Si bien estos dos conceptos suponen la utilización en un mismo marco excepcional y están encaminadas a la misma finalidad, los expertos han establecido algunas características, semejanzas y diferencias que sirven de referencia para clarificar cuándo es legítima su aplicación, para qué sirve su otorgamiento o a quiénes puede llegar a beneficiar. En ese orden de 
premisas, se han demarcado algunas características y connotaciones especiales sobre la amnistía, como las que se evidencian a continuación (Poveda Perdomo, Poveda Perdomo, \& Poveda Rodríguez, 2017, págs. 67-68):

(i). Requiere de una ley en sentido formal y material. Esto se explica por implicar una derogación ficta de la legislación penal, facultad prevista de manera exclusiva y excluyente en el legislador.

(ii). Implica una renuncia del Estado a la pretensión punitiva, bien porque no persigue el delito ora porque deja de ejecutar la pena.

(iii). Entraña un olvido de la infracción penal, es decir, extingue la acción penal y la condena.

(iv). Se ofrece teniendo en cuenta la infracción y no la persona.

(v). Dependiendo de la previsión normativa, puede producir efectos sobre la responsabilidad civil derivada del delito.

(vi). El otorgamiento depende de razones políticas (conveniencia pública).

(vii). Produce efectos hacia el pasado. Constituye un olvido del delito ejecutado.

(viii). Siempre es de carácter general, alcanza un grupo indeterminado de personas que reúnen los supuestos previstos en la norma.

(ix). Los beneficiados no pueden renunciar a ella.

(x). En principio no admite excepciones o exclusiones. 
(xi). Los beneficiados recuperan el pleno goce y ejercicio de todos sus derechos políticos y civiles.

(xii). Sus efectos se extienden a los delitos políticos y los conexos.

Igualmente, sobre el indulto se han establecido algunas características, así (Poveda Perdomo, et al., 2017, págs. 68-69):

(i). Se concede con fundamento en una ley en sentido formal y material. Esto se explica por implicar una derogación ficta de la legislación penal, facultad prevista de manera exclusiva y excluyente en el legislador.

(ii). Implica una renuncia del Estado a la pretensión punitiva.

(iii). Extingue la pena o libera de la condena total o parcialmente.

(iv). Puede ofrecerse teniendo en cuenta la infracción o la persona.

(v). Se puede otorgar en forma general o individual.

(vi). Subsiste la obligación de reparar el daño derivado del delito.

(vii). Produce efectos hacia el futuro.

(viii) Se decreta por razones políticas.

(ix). Sus beneficios son irrenunciables.

(x). En principio no admite excepciones o exclusiones, pero concedido de manera individual admite cierta discrecionalidad. 
(xi). Los beneficiarios recuperan el pleno goce y ejercicio de todos sus derechos, aunque eventualmente el legislador puede ordenar que el antecedente judicial subsista.

(xii). Sus efectos se extienden a los delitos políticos y los conexos.

De las características mencionadas y del estudio precedente, se pueden establecer algunas similitudes y diferencias de las instituciones que acá se estudian. En primer lugar, las similitudes más destacadas que existen entre la amnistía y el indulto son (i) que las dos se imponen por la facultad del Estado, (ii) que están dispuestas en la Constitución (iii) que deben ser desarrolladas por una ley, y (iv) que se imponen para extinguir la acción penal, sea total o parcialmente.

Por otro lado, las principales diferencias que marcan la distancia entre estas instituciones son las siguientes (Poveda Perdomo, et al., 2017, págs. 70-71):

1. La amnistía puede estar destinada a inhibir la facultad estatal de perseguir delitos o ejecutar las penas; el indulto se dirige a enervar la ejecución de la pena.

2. La amnistía extingue totalmente la acción penal, la condena y la responsabilidad civil derivada del delito.

Por su parte, el indulto generalmente extingue las sanciones impuestas, pero deja a salvo la responsabilidad civil (Congreso de Colombia, 2010), Ley de Orden Público, Artículo 64. En el mismo orden,

la amnistía está prevista exclusivamente para los delitos políticos y conexos, razón por la cual nunca puede ofrecerse por delitos comunes; el indulto eventualmente puede concederse 
a los responsables de delitos comunes, como ha ocurrido con los miembros de los grupos paramilitares. (Poveda Perdomo, et al., 2017, págs. 70-71)

Esas características, similitudes y diferencias se desarrollaron a continuación, de acuerdo con los postulados normativos y jurisprudenciales dispuestos para llegar a las inferencias que los diversos autores hicieron para llegar a las conclusiones planteadas.

\section{PERSPECTIVA NORMATIVA Y JURISPRUDENCIAL SOBRE LA AMNISTÍA Y EL INDULTO: ESPECIAL REFERENCIA AL CASO COLOMBIANO}

\subsection{Constitución, leyes y decretos}

La Constitución Política de 1991, específicamente el Artículo 35, prohibió la extradición por delitos políticos, por su parte, el Artículo 150, Numeral $17^{19}$, atribuyó al Congreso de la República la expedición de leyes de amnistías o indultos generales por delitos políticos.

En el mismo sentido fue delimitado el tema referente: quienes hayan cometido delitos no pueden ser congresistas, magistrados o diputados, exceptuando de dicha limitación a los responsables de delitos políticos, según lo establecieron los Artículos 179, Numeral 120, 232 Numeral $3^{21}$ y $299^{22}$ de la Constitución.

\footnotetext{
19 17. Conceder, por mayoría de los dos tercios de los votos de los miembros de una y otra Cámara y por graves motivos de conveniencia pública, amnistías o indultos generales por delitos políticos. En caso de que los favorecidos fueren eximidos de la responsabilidad civil respecto de particulares, el Estado quedará obligado a las indemnizaciones a que hubiere lugar.

${ }^{20}$ No podrán ser Congresistas: 1. Quienes hayan sido condenados en cualquier época por sentencia judicial, a pena privativa de la libertad, excepto por delitos políticos o culposos.

${ }^{21}$ Para ser Magistrado de la Corte Constitucional, de la Corte Suprema de Justicia y del Consejo de Estado se requiere: 3 . No haber sido condenado por sentencia judicial a pena privativa de la libertad, excepto por delitos políticos o culposos.

22 En cada departamento habrá una corporación político-administrativa de elección popular que se denominará asamblea departamental, la cual estará integrada por no menos de 11 miembros ni más de 31. Dicha corporación gozará de autonomía administrativa y presupuesto propio, y podrá ejercer control político sobre la administración departamental.

El régimen de inhabilidades e incompatibilidades de los diputados será fijado por la ley. No podrá ser menos estricto que el señalado para los congresistas en lo que corresponda. El período de los diputados será de cuatro años y tendrá la calidad de servidores públicos.
} 
Por su parte, el Artículo Transitorio 3023, autorizó al Gobierno Nacional para conceder indultos o amnistías por delitos políticos y conexos, cometidos con anterioridad a la promulgación de la Constitución de 1991. El Gobierno está facultado, según el Artículo 201, Numeral 2, para "conceder indultos por delitos políticos, con arreglo a la ley, e informar al Congreso sobre el ejercicio de esta facultad. En ningún caso estos indultos podrán comprender la responsabilidad que tengan los favorecidos respecto de los particulares." (Asamblea Nacional Constituyente, 1991)

Ahora bien, en diferentes marcos legales de carácter penal han sido previstas la aplicación de amnistías e indultos, así:

(i) El Código Penal de 1980, Artículo 78, estableció que la amnistía extinguía la acción penal y la pena, en tanto que el indulto solamente extinguía la pena (Congreso de la República de Colombia, 2000).

(ii) El Código Penal de 2000, en el capítulo dedicado a la extinción de la acción y de la sanción penal depuso, en el Artículo 82 y 88, respectivamente, a la amnistía propia como causal de extinción de la acción penal y la extinción de la pena aparecen relacionados el indulto y la amnistía impropia (Congreso de la República de Colombia, 2000).

\footnotetext{
Para ser elegido diputado se requiere ser ciudadano en ejercicio, no haber sido condenado a pena privativa de la libertad, con excepción de los delitos políticos o culposos y haber residido en la respectiva circunscripción electoral durante el año inmediatamente anterior a la fecha de la elección.

Los miembros de la Asamblea Departamental tendrán derecho a una remuneración durante las sesiones correspondientes y estarán amparados por un régimen de prestaciones y seguridad social, en los términos que fijen la ley.

23 Artículo transitorio 30. Autorízase al Gobierno Nacional para conceder indultos o amnistías por delitos políticos y conexos, cometidos con anterioridad a la promulgación del presente Acto Constituyente, a miembros de grupos guerrilleros que se reincorporen a la vida civil en los términos de la política de reconciliación. Para tal efecto el Gobierno Nacional expedirá las reglamentaciones correspondientes. Este beneficio no podrá extenderse a delitos atroces ni a homicidios cometidos fuera de combate o aprovechándose del estado de indefensión de la víctima.
} 
Otras leyes, como la la Ley de Orden Público de 1997 (Congreso de Colombia, 1997), prorrogada y modificada por las Leyes 548 de 1999, 782 de 2002, 1106 de 2006, 1421 de 2010, 1738 de 2014 y 1779 de 2016, estableció el indulto como un beneficio a conceder por el Gobierno Nacional a quienes fueren condenados por delitos políticos, cuando individualmente o junto al grupo armado organizado al margen de la ley con el que se adelante un proceso de paz, demuestre su voluntad de reintegrarse, visto específicamente en su Artículo 50, así:

El Gobierno Nacional podrá conceder, en cada caso particular, el beneficio de indulto a los nacionales que hubieren sido condenados mediante sentencia ejecutoriada, por hechos constitutivos de los delitos políticos de rebelión, sedición, asonada, conspiración y los conexos con éstos, cuando a su criterio, la Organización Armada al margen de la ley a la que se le reconozca el carácter político, del cual forme parte el solicitante, haya demostrado su voluntad de reincorporarse a la vida civil.

De acuerdo con lo expuesto, la connotación política de la amnistía que se concede mediante una ley para cesar la acción penal o la pena impuesta por delitos políticos y conexos, produce efectos extintivos sobre el delito, las penas principales y accesorias y desaparece la responsabilidad civil, so pena, siempre, de la reparación de las víctimas.

Según la norma, la amnistía puede ser de dos formas: (i) propia, cuando sus efectos extintivos recaen sobre la acción penal, según lo dispuesto en el Artículo 82 del Código Penal; o (ii) impropia, cuando se extingue la pena o sanción impuesta al responsable del delito, según lo estatuido en el Artículo 88 del Código Penal (Congreso de la República de Colombia, 2000).

Por su parte, de acuerdo con lo decantado por las normas, el indulto puede llegar a ser comprendido como aquella institución de carácter jurídica, también de connotación política, que 
se concede mediante ley para cesar total o parcialmente las penas impuestas a los responsables de delitos políticos y los conexos con ellos, produciendo efectos extintivos sobre las penas principales y accesorias.

\subsection{Hermenéutica jurisprudencial sobre la amnistía y el indulto}

La Sala de Casación Penal de la Corte Suprema de Justicia colombiana, como ente encargado de velar por la justicia penal ordinaria, consideró que la amnistía y el indulto son

instituciones que proceden del poder soberano del Estado y conllevan un derecho de gracia; la amnistía dimana del órgano legislativo y está llamada a dejar en el olvido las infracciones a que se refiere; (...) el indulto está reservado al Presidente de la República, requiere que haya terminado la actuación procesal y permite solo la extinción de la pena. (Corte Suprema de Justicia, Sala Penal, 1986)

Del mismo modo, en Sentencia 094 del 12 de julio de 1990, consideró que una mayoría de los Estados de la modernidad disponen algunas instituciones o estados de "excepción para sortear episodios extraordinarios o graves situaciones de conflicto social que atentan contra el equilibrio político, institucional o económico, a fin de asegurar la plena vigencia del orden jurídico, de las instituciones democráticas y recuperar la paz social" (Corte Suprema de Justicia, Sala Penal, 1990).

Agregó dicha decisión de la Corte que:

nuestro ordenamiento constitucional, en prescripciones que datan de la Constitución de 1886 contempla esas dos instituciones especiales de carácter político (la amnistía y el indulto), con consecuencias en el campo penal, como modalidades extraordinarias de 
indulgencia, y son expresión de la facultad del poder soberano del Estado que por este medio renuncia circunstancialmente, tratándose de la amnistía, a su potestad de perseguir y castigar los delitos en virtud de requerimientos graves de interés público y en particular por causas de carácter político, cubriendo con el manto del olvido al hecho que en antes fue delictuoso, y autorizando para tal fin, la extinción de la acción penal y de la pena, por delitos políticos. (Corte Suprema de Justicia, Sala Penal, 1990)

Precisó, además, que:

el indulto es el acto de gracia en virtud del cual se concede al delincuente el perdón de las penas impuestas judicialmente, librándolo de su ejecución en todo o en la parte que falte al momento de concederse la indulgencia; a diferencia de la amnistía que se refiere al delito borrando su criminalidad, el indulto implica sólo perdón de la pena pero no despoja al hecho de su carácter ilícito y de su tipicidad penal. (Corte Suprema de Justicia, Sala Penal, 1990).

En la misma providencia se dejó en claro que:

por implicar la amnistía renuncia del Estado a su potestad soberana de perseguir y castigar los delitos, y tener como ya se anotó el carácter de medida general e impersonal, su concesión es atributo privativo del Poder Legislativo; por otro lado, el indulto es particular ya que se refiere a determinada o determinadas personas, se concede por el Presidente de la República por acto administrativo según las condiciones generales señaladas por la ley. (Corte Suprema de Justicia, Sala Penal, 1990)

En la Sentencia C-179 de 1994 resumió que: 
conceder amnistías o indultos generales por delitos políticos es una medida eminentemente política, que implica interpretar la voluntad de la Nación. Si el Congreso, con el voto de la mayoría exigida por la Constitución, dicta esta medida, será porque interpreta el sentimiento de la inmensa mayoría de los ciudadanos y si la niega, será porque no existe ese sentimiento. (Corte Constitucional, 1994)

Según lo considerado en Sentencias C-179 de 1994, C-245 de 1996 y C-768 de 1998 de la Corte Constitucional, reiteradamente se ha señalado que "tanto la amnistía como el indulto son instrumentos netamente políticos que puede utilizar el Estado con el fin de lograr la reconciliación y la paz en su territorio” (Corte Constitucional, 1994).

En los fallos C-928 de 2005 y C-370 de 2006, citados en la decisión C-577 de 2014, se consideró lo siguiente:

la amnistía y el indulto son dispositivos jurídicos extraordinarios orientados a la superación de situaciones de conflicto social y a restablecer el orden jurídico; que la primera es el olvido de la comisión del delito político y técnicamente la extinción de la acción penal respectiva, y tiene carácter general o abstracto, y que el segundo es el perdón de la sanción aplicable por dicha comisión y técnicamente la extinción de la pena impuesta por las autoridades judiciales mediante sentencia ejecutoriada, y tiene carácter particular o concreto. (Corte Constitucional, 2014).

Específicamente en sentencia T-177 de 2011, definió el indulto como una herramienta jurídica que busca dar solución a los graves problemas políticos derivados del conflicto armado, enervando las penas impuestas a quienes hayan sido sancionados por haber sido encontrados responsables de delitos políticos y conexos (Corte Constitucional, 2011). 
En relación con el otorgamiento de amnistías, en los términos del Protocolo Adicional II a los Convenios de Ginebra del 12 de agosto de 1949, relativo a la protección de las víctimas de los conflictos armados sin carácter internacional, suscrito en Ginebra el 8 de junio de 1977, adoptado para el orden mediante la Ley 171 de 1994, la Corte Constitucional, en Sentencia C225 de 1995 consideró que:

el Protocolo II no está obligando al Estado a conceder obligatoriamente amnistías, ya que la norma establece únicamente que las autoridades "procurarán" conceder este tipo de beneficios penales. Además, este artículo del Protocolo II tampoco ordena al Estado a amnistiar todos los delitos cometidos durante la confrontación armada, puesto que simplemente señala que la amnistía será "lo más amplia posible". Y, finalmente, teniendo en cuenta las consideraciones hechas en el punto anterior, es obvio que esas amnistías se refieren precisamente a los delitos políticos o conexos, puesto que ésos son los que naturalmente derivan de "motivos relacionados con el conflicto". Esto significa entonces que el Estado colombiano se reserva el derecho de definir cuáles son los delitos de connotación política que pueden ser amnistiados, si lo considera necesario, para lograr la reconciliación nacional, una vez cesadas las hostilidades. Es pues una opción política perfectamente compatible con la Carta, puesto que ésta establece que el Legislador podrá en todo momento "conceder, por mayoría de dos tercios de los miembros de una y otra Cámara y por graves motivos de conveniencia pública, amnistías o indultos generales por delitos políticos" (CP art. 150-17). Además, la posibilidad de que se concedan amnistías o indultos generales para los delitos políticos y por motivos de conveniencia pública es una tradición consolidada del constitucionalismo colombiano, puesto que ella se 
encuentra en todas nuestras constituciones de la historia republicana, desde la Carta de 1821 hasta la actual Carta. (Corte Constitucional, 1995)

Según lo citado, los fundamentos que sirvieron para la expedición de leyes de amnistía e indulto se ligan inevitablemente con el conflicto armado interno, pero también está irrogado por la conveniencia política, pues se ha llegado a otorgar amnistía e indultos a responsables de conductas delictivas que bajo ninguna circunstancia es posible calificar como delitos políticos o conexos.

\section{LA AMNISTÍA Y EL INDULTO EN EL MARCO DEL ACUERDO FINAL Y SU DESARROLLO DESDE LA PERSPECTIVA JURISPRUDENCIAL}

\subsection{Tratamientos sobre la amnistía y el indulto en el Acuerdo Final para la Paz}

Según el Acuerdo Final para la Paz, la amnistía y el indulto deben ser entendidos como instrumentos de su implementación dirigidos a la obtención de la paz, pero especialmente a la determinación de la verdad de lo ocurrido con el fin de otorgar a las víctimas la garantía del derecho a la verdad, hasta el punto de que dichas prerrogativas están sometidas al otorgamiento de la verdad de lo sucedido y el esclarecimiento del porqué del conflicto armado.

En el referido Acuerdo se estableció que el Gobierno Nacional coordinaría la revisión de la situación de las personas privadas de la libertad, procesadas o condenadas, por pertenecer o colaborar con las FARC-EP. Solamente en el Acuerdo sobre las Víctimas del Conflicto se hizo referencia expresa al otorgamiento de amnistía a los miembros de las FARC-EP, cuando dispuso que: 
a la terminación de las hostilidades, la amnistía para los rebeldes únicamente estará condicionada a la finalización de la rebelión de las respectivas organizaciones armas y al cumplimiento de los establecido en el Acuerdo Final, sin perjuicio de lo dispuesto en los puntos 23 y 27 (Gobierno Nacional-FARC-EP, 2016, p. 145),

que, respectivamente, indicaron lo siguiente:

23. A la finalización de las hostilidades, de acuerdo con el DIH, el Estado colombiano puede otorgar la amnistía "más amplia posible". A los rebeldes que pertenezcan a organización que hayan suscrito un acuerdo final de paz, según lo establecido en el numeral 10, así como a aquellas personas que hayan sido acusadas o condenadas por delitos políticos o conexo mediante providencias proferidas por la justicia, se otorgará la más amplia amnistía posible, respetando lo establecido al respecto en el presente documento, conforme a lo indicado en el numeral 38.

27. La concesión de amnistías o indultos o el acceso a cualquier tratamiento especial, no exime del deber de contribuir, individual o colectivamente, al esclarecimiento de la verdad conforme a lo establecido en este documento (Gobierno Nacional-FARC-EP, 2016, págs. 147-148).

En el Acuerdo Final firmado en el Teatro Colón se determinó de manera precisa el compromiso de conceder amnistía y, seguidamente, como consecuencia de ella, la libertad de los guerrilleros detenidos o condenados. Por lo que se hace indispensable referenciar lo que obra en el Acuerdo sobre la amnistía y el indulto. En el punto 3, sobre el fin del conflicto armado, se fijaron las zonas veredales transitorias de normalización (ZVTN), mediante las cuales se busca que los integrantes del grupo al margen de la ley a los que se les haya concedido amnistías en 
virtud de la Ley 1820 de $2016^{24}$ y reglamentaciones subsiguientes, sigan con el proceso de reincorporación a la vida civil (Gobierno Nacional-FARC-EP, 2016, p. 61).

En la subsección sobre la Reincorporación de las FARC-EP a la vida civil, que hace referencia a la parte económica, social y política y sobre la acreditación y el tránsito a la legalidad, se destaca que en el Acuerdo se dispuso la creación de un procedimiento expedito para la acreditación y el tránsito a la legalidad de los miembros de las FARC-EP no armados. Para tal fin se especificó lo siguiente:

A las personas que sean acreditadas se les resolverá la situación jurídica otorgándoles indulto mediante los instrumentos legales vigentes si no estuviera en vigor la ley de amnistía. Quedarán en libertad a disposición de la JEP en caso de que tuvieran acusaciones por delitos no amnistiables según la Ley de Amnistía acordada en el Acuerdo Final. Se les aplicará en todo lo que les resulte favorable lo establecido en el "Acuerdo del 20 de agosto de 2016 para facilitar la ejecución del cronograma del proceso de dejación de armas alcanzado mediante acuerdo del 23 de junio de 2016" (Gobierno Nacional-FARC-EP, 2016, p. 72).

Concretamente en el Acuerdo sobre las Víctimas del Conflicto Armado, donde se incluyó la Jurisdicción Especial para la Paz, se hizo referencia a su integración con una Sala de Amnistía e Indulto (Gobierno Nacional-FARC-EP, 2016, p. 157) y se dedicó un gran parte del Punto 5 del Acuerdo Final a identificar los contenidos, alcances y límites de la concesión de amnistías e indultos así como de otros tratamientos especiales. Así, en una primera parte, se expuso todo

\footnotetext{
${ }^{24}$ Por medio de la cual se dictan disposiciones sobre amnistía, indulto y tratamientos penales especiales y otras disposiciones.
} 
acerca de los derechos de las víctimas, los marcos jurídicos para el reconocimiento de los mismos y los deberes del estado colombiano en materia de derechos, de la siguiente manera:

17. El Sistema Integral de Verdad, Justicia, Reparación, y No Repetición, tendrá como finalidades primordiales la consolidación de la paz, y la garantía de los derechos de las víctimas.

18. El resultado final de la aplicación del Sistema Integral de Verdad, Justicia, Reparación, y No Repetición, debe garantizar la seguridad jurídica para promover una paz estable y duradera.

19. Para efectos del SIVJRNR, los marcos jurídicos de referencia incluyen principalmente el Derecho Internacional en materia de Derechos Humanos (DIDH) y el Derecho Internacional Humanitario (DIH). Las secciones del Tribunal para la Paz, las Salas y la Unidad de Investigación y Acusación, al adoptar sus resoluciones o sentencias harán una calificación jurídica propia del Sistema respecto a las conductas objeto del mismo, calificación que se basará en el Código Penal colombiano y/o en las normas de Derecho Internacional en materia de Derechos Humanos (DIDH), Derecho Internacional Humanitario (DIH) o Derecho Penal Internacional (DPI), siempre con aplicación del principio de favorabilidad. La calificación resultante podrá ser diferente a la efectuada con anterioridad por las autoridades judiciales, disciplinarias o administrativas para la calificación de esas conductas, por entenderse aplicable como marco jurídico de referencia el Derecho Internacional.

20. Las víctimas gozan de los derechos a la Verdad, Justicia, Reparación y garantías de No Repetición. Para garantizar estos derechos participarán en el SIVJRNR conforme a lo 
establecido en los reglamentos de desarrollo del componente de justicia, y, entre otros, deberán ser oídas en los supuestos de priorización y selección de casos. Los reglamentos deberán respetar el derecho de las víctimas a una justicia pronta, cumplida y eficiente.

21. Igualmente, el Estado colombiano tiene el deber de asegurar, por medios razonables dentro de su alcance, la verdad, justicia, reparación, y medidas de no repetición, con respecto a las graves infracciones del DIH y graves violaciones de los Derechos Humanos. (Gobierno Nacional-FARC-EP, 2016, p. 147-152)

En materia de justicia, el Acuerdo demarcó los límites para el juzgamiento de los responsables de los graves delitos, las prerrogativas que pueden tener los perpetradores, entes del estado y los ciudadanos que contribuyeron con el conflicto, diferenciando cuáles delitos son amnistiables y cuáles no. Así:

22. En materia de justicia, conforme al DIDH, el Estado colombiano tiene el deber de investigar, esclarecer, perseguir y sancionar las graves violaciones del DIDH y las graves infracciones del DIH.

23. A la finalización de las hostilidades, de acuerdo con el DIH, el Estado colombiano puede otorgar la amnistía "más amplia posible". A los rebeldes que pertenezcan a organizaciones que hayan suscrito un acuerdo final de paz, según lo establecido en el numeral 10, así como a aquellas personas que hayan sido acusadas o condenadas por delitos políticos o conexos mediante providencias proferidas por la justicia, se otorgará la más amplia amnistía posible, respetando lo establecido al respecto en el presente documento, conforme a lo indicado en el numeral 38. 
24. La Constitución permite otorgar amnistías o indultos por el delito de rebelión y otros delitos políticos y conexos.

25. Hay delitos que no son amnistiables ni indultables de conformidad con los numerales 40 y 41 de este documento. No se permite amnistiar los crímenes de lesa humanidad, ni otros crímenes definidos en el Estatuto de Roma.

26. Es necesario determinar claramente cuáles son los delitos que son amnistiables o indultables y aquellos que no lo son, para efectos de seguridad jurídica. A tal fin, las normas de amnistía que se adopten respetarán los principios establecidos en el presente documento de creación de la JEP. Al momento de determinar las conductas amnistiables o indultables, se aplicará el principio de favorabilidad para el destinatario de la amnistía o indulto, cuando no existiera en el derecho internacional una prohibición de amnistía o indulto respecto a las conductas de que se hubiera acusado a los rebeldes o a otras personas acusadas de serlo. El principio de favorabilidad se aplicará a todos los destinatarios de la JEP.

27. La concesión de amnistías o indultos o el acceso a cualquier tratamiento especial, no exime del deber de contribuir, individual o colectivamente, al esclarecimiento de la verdad conforme a lo establecido en este documento.

28. El grado de contribución voluntaria de cada persona o colectivo a la verdad estará en relación con el tratamiento a recibir en el componente de justicia.

29. Se determinará de manera clara el alcance de cada uno de los delitos que no son amnistiables y de los que sí lo son, para efectos de seguridad jurídica. 
30. Los delitos no amnistiables ni indultables deben ser objeto del componente de justicia del Sistema integral de Verdad, Justicia, Reparación y No Repetición (SIVJRNR) acordado por las partes.

31. En el componente de justicia se establecerán sanciones a los responsables en aquellos casos en los que se determine que no los alcanza la amnistía o el indulto.

32. El componente de justicia del Sistema Integral de Verdad, Justicia, Reparación, y No Repetición se aplicará a todos los que participaron de manera directa o indirecta en el conflicto armado. Se aplicará a los investigados o condenados por el delito de rebelión u otros relacionados con el conflicto, aunque no pertenezcan a las organizaciones armadas en rebelión.

Respecto de los combatientes de los grupos armados al margen de la ley, el componente de justicia del Sistema solo se aplicará a quienes suscriban un acuerdo final de paz con el Gobierno Nacional.

También serán de competencia de la Jurisdicción Especial para la Paz las conductas de financiación o colaboración con los grupos paramilitares, o con cualquier actor del conflicto, que no sean resultado de coacciones, respecto de aquellas personas que tuvieron una participación activa o determinante en la comisión de los crímenes competencia de esta jurisdicción, según lo establecido en el numeral 40, salvo que previamente hubieren sido condenadas por la justicia por esas mismas conductas. Los órganos de la JEP decidirán, según el caso, el procedimiento apropiado. De conformidad con el numeral 48 (t) y el 58 (e) serán llamados a comparecer ante la Jurisdicción Especial para la Paz, por parte de la Sección de Revisión del Tribunal, aquellas personas 
que hubieran tenido una participación determinante en una de las conductas de que trata el numeral 40 y no hubieren comparecido previamente ante la Sala de Verdad y Reconocimiento.

El componente de Justicia también se aplicará respecto de los agentes del Estado que hubieren cometido delitos relacionados con el conflicto armado (...).

Se entiende por agente del Estado a efectos de la Jurisdicción Especial para la Paz toda persona que al momento de la comisión de la presunta conducta criminal estuviere ejerciendo como miembro de las corporaciones públicas, como empleado o trabajador del Estado o de sus entidades descentralizadas, territorialmente y por servicios, que haya participado en el diseño o ejecución de conductas delictivas relacionadas directa o indirectamente con el conflicto armado. (...)

33. El componente de justicia del SIVJRNR, conforme a lo establecido en el Acuerdo Final, prevalecerá sobre las actuaciones penales, disciplinarias o administrativas por conductas cometidas con ocasión, por causa y en relación directa o indirecta con el conflicto armado, al absorber la competencia exclusiva sobre dichas conductas.

34. El tratamiento de justicia para los integrantes de las FARC-EP, para los agentes del Estado y para otros actores que hayan participado en el conflicto, ya sea como combatientes o como no combatientes, cuando hayan cometido delitos, puede ser diferente pero equilibrado y equitativo.

35. La protesta pacífica, la defensa de los Derechos Humanos, y el liderazgo de grupos de la sociedad civil, no pueden ser por sí mismos tipificados penalmente, ni penados. En 
caso de haber sido sancionados se otorgarán mecanismos de tratamiento especial que puedan llegar incluso hasta la extinción de la responsabilidad. La Sala de Amnistía e Indulto y la Sección de Revisión del Tribunal para la Paz serán competentes para decidir si extingue, revisa o anula las sanciones, investigaciones y sentencias impuestas en los anteriores supuestos.

36. La imposición de cualquier sanción en el SIVJRNR no inhabilitará para la participación política ni limitará el ejercicio de ningún derecho, activo o pasivo, de participación política, para lo cual las partes acordarán las reformas constitucionales pertinentes.

37. Se aplicará el artículo 6.5 del Protocolo II de los Convenios de Ginebra, del cual Colombia es Estado Parte, el cual dispone lo siguiente: “a la cesación de las hostilidades, las autoridades en el poder procurarán conceder la amnistía más amplia posible a las personas que hayan tomado parte en el conflicto armado o que se encuentren privadas de libertad, internadas o detenidas por motivos relacionados con el conflicto armado." (Gobierno Nacional-FARC-EP, 2016, p. 147-152)

Igualmente, de acuerdo con los estándares internacionales de justicia transicional, se habló sobre las categorías de delitos que pueden ser sujetos a amnistías e indultos, por lo que se tomaron solamente los delitos políticos y los conexos con ellos, además de establecer algunos limitantes a la Ley de Amnistías que posteriormente fue expedida por el Congreso de la República en virtud de sus facultades. En contexto, el Acuerdo Final para la Paz suscribió lo siguiente: 
38. Conforme a la anterior disposición, se amnistiarán e indultarán los delitos políticos y conexos cometidos en el desarrollo de la rebelión por las personas que formen parte de los grupos rebeldes con los cuales se firme un acuerdo de paz. Respetando lo establecido en el Acuerdo Final y en el presente documento, las normas de amnistía determinarán de manera clara y precisa los delitos amnistiables o indultables y los criterios de conexidad. La pertenencia al grupo rebelde será determinada, previa entrega de un listado por dicho grupo, conforme a lo que se establezca entre las partes para su verificación. Entre los delitos políticos y conexos se incluyen, por ejemplo, la rebelión, la sedición, la asonada, así como el porte ilegal de armas, las muertes en combate compatibles con el Derecho Internacional Humanitario, el concierto para delinquir con fines de rebelión y otros delitos conexos. Para decidir sobre la conexidad con el delito político de conductas delictivas relacionadas con cultivos de uso ilícito, se tendrán en cuenta los criterios manifestados por la jurisprudencia interna colombiana con aplicación del principio de favorabilidad. Los mismos criterios de amnistía o indulto se aplicarán a personas investigadas o sancionadas por delitos de rebelión o conexos, sin que estén obligadas a reconocerse como rebeldes.

39. La conexidad con el delito político comprenderá dos criterios, uno de tipo incluyente y otro de tipo restrictivo. El primer criterio consistirá en incluir como conexos: $1^{\circ}$.aquellos delitos relacionados específicamente con el desarrollo de la rebelión cometidos con ocasión del conflicto armado, como es por ejemplo la aprehensión de combatientes efectuada en operaciones militares; $2^{\circ}$.- los delitos en los cuales el sujeto pasivo de la conducta es el Estado y su régimen constitucional vigente; y $3^{\circ}$.- las conductas dirigidas a 
facilitar, apoyar, financiar u ocultar el desarrollo de la rebelión, para lo cual deberán definirse cada uno de los contenidos de las anteriores conductas. Se entenderá como conducta dirigida a financiar la rebelión todas aquellas conductas ilícitas de las que no se haya derivado enriquecimiento personal de los rebeldes ni sean consideradas crimen de lesa humanidad, grave crimen de guerra o genocidio.

La Sala de Amnistía e Indulto determinará la conexidad con el delito político caso a caso.

40. No serán objeto de amnistía ni indulto ni de beneficios equivalentes los delitos de lesa humanidad, el genocidio, los graves crímenes de guerra -esto es, toda infracción del Derecho Internacional Humanitario cometida de forma sistemática o como parte de un plan o política-, la toma de rehenes u otra privación grave de la libertad, la tortura, las ejecuciones extrajudiciales, la desaparición forzada, el acceso carnal violento y otras formas de violencia sexual, la sustracción de menores, el desplazamiento forzado, además del reclutamiento de menores, todo ello conforme a lo establecido en el Estatuto de Roma.

En la ley de amnistía se determinarán las conductas tipificadas en la legislación nacional que no serán amnistiables, siempre que se correspondan con los enunciados anteriores.

Las normas precisarán el ámbito y alcance de estas conductas en concordancia con lo previsto en el Estatuto de Roma, en el Derecho Internacional de los Derechos Humanos y en el Derecho Internacional Humanitario.

41. Tampoco son amnistiables o indultables en el SIVJRNR, los delitos comunes que carecen de relación con la rebelión, conforme a lo determinado en la ley de amnistía. 
42. Las investigaciones en curso y las sanciones disciplinarias y/o administrativas también se extinguirán cuando hayan sido impuestas por conductas o actuaciones relacionadas con el conflicto armado o la rebelión. En la aplicación de este tratamiento se atenderá a las conductas que podrían ser amnistiables o indultables, según la ley de amnistía.

43. La concesión de amnistías e indultos no extingue el derecho de las víctimas a recibir reparación.

44. En concordancia con lo anterior, respecto a los agentes del Estado, se establece un tratamiento especial, simultáneo, equilibrado y equitativo basado en el Derecho Internacional Humanitario. Dicho tratamiento diferenciado valorará lo establecido en las reglas operacionales de la fuerza pública en relación con el DIH. En ningún caso la responsabilidad del mando podrá fundarse exclusivamente en el rango, la jerarquía o el ámbito de jurisdicción. La responsabilidad de los miembros de la fuerza pública por los actos de sus subordinados deberá fundarse en el control efectivo de la respectiva conducta, en el conocimiento basado en la información a su disposición antes, durante y después de la realización de la respectiva conducta, así como en los medios a su alcance para prevenir, y de haber ocurrido, promover las investigaciones procedentes. (Gobierno Nacional-FARC-EP, 2016, p. 147-152)

Otro aparte del Acuerdo Final se dedica a desarrollar específicamente lo relacionado con la creación de la Jurisdicción Especial para la Paz; como la JEP ya fue puesta en funcionamiento, las decisiones de excarcelación, el traslado y la supervisión de la medida de control y garantía son propias de dicha corporación, por lo que será su competencia tomar las decisiones respecto a 
los excarcelados a través de la Sección de revisión del Tribunal para la Paz (Gobierno NacionalFARC-EP, 2016, p. 176).

Todas las personas que queden en libertad en virtud de la Ley de Amnistía quedarán a disposición de la Jurisdicción Especial para la Paz y deberán comparecer ante la misma para que la Sala de Amnistía e Indulto, la Sala de Verdad y Reconocimiento de Responsabilidad, la Sala de Definición de Situaciones Jurídicas o la Sección de Revisión del Tribunal para la Paz, resuelvan su situación, lo que quiere decir que la liberación no es óbice para la extinción de responsabilidades (Gobierno Nacional-FARC-EP, 2016, p. 177).

Más adelante aparece en el Acuerdo Final una sección referida a las prioridades de implementación, en la que se refiere que el Gobierno Nacional garantizará que el Acuerdo Final se incorporará conforme a las normas constitucionales, se tramitarán los proyectos normativos conforme al procedimiento establecido en el Acto Legislativo 1 de 2016 o mediante otro Acto legislativo en caso de que el anterior procedimiento no estuviera vigente (Gobierno NacionalFARC-EP, 2016, págs. 200-201).

Específicamente sobre la ley de amnistía, indultos y tratamientos penales especiales, en el Acuerdo Final se pactó que el Gobierno Nacional presentaría ante el Congreso de la República la propuesta de proyecto de ley para dichos tratamiento penales especiales. Dicho proyecto debe contener lo siguiente:

- Un primer título relativo a su objeto y principios, aplicables a todos sus destinatarios. 
- Un segundo título relativo a las amnistías, indultos y otros tratamientos penales especiales.

- Un tercer título relativo a los tratamientos penales especiales diferenciados para agentes del Estado.

- Y un cuarto título relativo a disposiciones finales, aplicables a todos sus destinatarios. (Gobierno Nacional-FARC-EP, 2016, p. 279)

De lo anterior, surgieron la Ley 1820 de 2016, por medio de la cual se dictan disposiciones sobre amnistía, indulto y tratamientos penales especiales y otras disposiciones, y el decreto 277 de 2017, por el cual se establece el procedimiento para la efectiva implementación de la Ley 1820 del 30 de diciembre de 2016, en cumplimiento con las disposiciones y principios adoptados en el Acuerdo Final para la Paz.

El Acuerdo resulta obligatorio para la totalidad de las autoridades nacionales, de modo que las decisiones de todas las instituciones del Estado tienen que estar ceñidas a sus disposiciones; porque al ir en contravía de este, resultaría violatorio del derecho fundamental a la paz, debido a que se podría llegar a provocar la desestabilización de lo pactado y en ese sentido perder la posibilidad de Paz creada.

De acuerdo al hilo conductor, si una autoridad pública inaplica lo pactado, podría ponerse en situación de alguna de las causales de procedibilidad de la acción de tutela o del hábeas corpus, como quedó establecido en el desarrollo del Decreto 277 de 2017, especialmente en sus Artículos 3 y 19, por cuanto este último asevera que "los beneficios previstos en la Ley 1820 de 2016, se aplicarán sin perjuicio de la interposición de la acción de tutela y hábeas corpus a que 
haya lugar", por lo que si un juez no tramita o se niega a resolver oportunamente una petición de amnistía, habilita el amparo constitucional. Así mismo, en los casos de procedencia de la amnistía, el hábeas corpus permite que el beneficiado con ella consiga que cese la captura ilegal o la prolongación ilícita de la privación de la libertad (Poveda Perdomo \& Poveda Perdomo, 2014).

\subsection{Explicación y desarrollo normativo de la ley de amnistía e indulto desde la perspectiva jurisprudencial}

Con el fin de cumplir con las disposiciones del Acuerdo Final, los títulos exigidos para la expedición de la norma reguladora de la concesión de amnistías e indultos, el Congreso de la República de Colombia expidió la Ley 1820 el 30 de diciembre de 2016, por medio de la cual se dictan disposiciones sobre amnistía, indulto y tratamientos penales especiales y otras disposiciones; posteriormente, el Presidente de la República expide el Decreto 277 de 2017, a través del cual se establece el procedimiento para la efectiva implementación de la Ley 1820 del 30 de diciembre de 2016, y el Decreto 522 de 2018, por el cual, entre otras cosas, se reglamenta parcialmente la Ley 1820 de 2016.

La Corte Suprema de Justicia, a través de la Sala de Casación Penal en las decisiones tomadas con respecto de la Ley 1820 de 2016, realizó análisis mediante los cuales se realizan precisiones sobre la amnistía de iure, la amnistía que no es de iure, la justicia transicional, la extradición, la libertad transitoria y condicionada, la suspensión de la ejecución de las órdenes de captura y la competencia de la justicia ordinaria. Indicó que los destinatarios de la Ley 1820 de 2016 son los integrantes de las FARC-EP incluidos en los listados elaborados por los 
representantes del grupo y quienes hayan sido condenados, procesados o investigados por su pertenencia o colaboración con esa agrupación, con independencia de que se hayan desmovilizado del grupo con antelación a la firma del acuerdo; es decir, que estén postulados a Justicia y Paz. (Corte Suprema de Justicia, Auto AP2445, 2017)

Por otro lado, la Corte Suprema manifestó, en lo que atañe a los agentes del Estado, que el Artículo $9^{25}$ de la Ley 1820 de 2016 dispuso que estos no recibirán amnistía ni indulto; sin embargo, si hubieren cometido delitos con ocasión, por causa, o en relación directa o indirecta con el conflicto armado antes de la entrada en vigor del Acuerdo Final de Paz, recibirán un tratamiento penal especial diferenciado, simétrico, equitativo, equilibrado y simultáneo, a excepción de aquellos agentes que hayan cometido delitos de lesa humanidad o contra el servicio de la Fuerza Pública.

No obstante, mientras se decide lo anterior, a los agentes del Estado les será concedida la libertad transitoria condicionada y anticipada, siempre que al momento de entrar en vigencia la Ley 1820 de 2016 estén detenidos o condenados y acepten su sometimiento a la Sala de Definición de Situaciones Jurídicas de la Jurisdicción Especial para la Paz, con el fin de acogerse a la renuncia de la persecución penal, pues, de acuerdo con el Artículo $51^{26}$ de la misma Ley,

\footnotetext{
${ }^{25}$ Artículo $9^{\circ}$. Tratamiento penal especial, simétrico, simultáneo, equilibrado y equitativo. Los agentes del Estado no recibirán amnistía ni indulto. Los agentes del Estado que hubieren cometido delitos con ocasión, por causa, o en relación directa o indirecta con el conflicto armado antes de la entrada en vigor del Acuerdo Final de Paz, recibirán un tratamiento penal especial diferenciado, simétrico, equitativo, equilibrado y simultaneo de conformidad con esta ley.

${ }^{26}$ Artículo 51. Libertad transitoria condicionada y anticipada. La libertad transitoria condicionada y anticipada es un beneficio propio del sistema integral expresión del tratamiento penal especial diferenciado, necesario para la construcción de confianza y facilitar la terminación del conflicto armado interno, debiendo ser aplicado de manera preferente en el sistema penal colombiano, como contribución al logro de la paz estable y duradera. Este beneficio se aplicará a los agentes del Estado, que al momento de entrar en vigencia la presente ley, estén detenidos o condenados que manifiesten o acepten su sometimiento a la Sala de Definición de Situaciones Jurídicas de la Jurisdicción Especial para la Paz, con el fin de acogerse al mecanismo de la renuncia a la persecución penal. Dicha manifestación o aceptación de sometimiento se hará ante el Secretario Ejecutivo de la Jurisdicción Especial para la Paz, en caso de que no haya entrado en funcionamiento la Sala de Definición de Situaciones Jurídicas. El otorgamiento de la libertad transitoria, condicional y anticipada es un beneficio que no implica la definición de la situación jurídica definitiva en el marco de la Jurisdicción especial para la Paz. Parágrafo $10 \bullet$ Para el caso de los miembros de la Fuerza Pública en servicio activo, la libertad transitoria condicionada y anticipada implica el levantamiento de la suspensión del ejercicio de funciones y atribuciones, salvo que se trate homicidio, tráfico de armas, concierto para delinquir o los demás delitos del
} 
Jurídicas, quien, de cumplirse los requisitos legales contemplados en el Artículo $52^{27}$, así lo comunicará al respectivo funcionario judicial, conforme lo establece el Artículo $53^{28}$ (Corte Suprema de Justicia, Auto AP3004, 2017).

Sobre la amnistía de iure manifestó que la competencia para disponer dicha amnistía radica en el Juez de Conocimiento a instancia de la Fiscalía General de la Nación, según lo

artículo 46 de la presente ley. En todo caso, el levantamiento de la suspensión del ejercicio 4e funciones y atribuciones no procede para quienes se encuentren 22 investigados por delitos con una pena mínima privativa de la libertad de 5 o más años. Para todos los efectos de administración de personal en la Fuerza Pública la libertad transitoria condicionada y anticipada tendrá las mismas consecuencias que la libertad provisional, salvo que se trate de homicidio, tráfico de armas, concierto para delinquir o los demás delitos del artículo 46 de la presente ley o de los delitos con una pena mínima privativa de la libertad de 5 o más años. Los miembros de la Fuerza Pública investigados de que trata el presente parágrafo, una vez levantada la suspensión de funciones y atribuciones y cuando la Jurisdicción Especial para la Paz haya declarado su competencia para conocer del caso, tendrán derecho a que se compute para efecto de la asignación de retiro el tiempo que estuvieron privados efectivamente de la libertad con anterioridad a la entrada en funcionamiento de la JEP. Lo anterior, siempre y cuando hayan seguido efectuando sus respectivos aportes, sin que ello implique un reconocimiento para efecto de la liquidación de las demás prestaciones. 20 Parágrafo • En ningún caso los condenados y/o sancionados serán reintegrados al servicio activo.

${ }^{27}$ Artículo 52. De los beneficiarios de la libertad transitoria condicionada y anticipada. Se entenderán sujetos beneficiarios de la libertad transitoria condicionada y anticipada aquellos agentes del Estado que cumplan los siguientes requisitos: 1. Que estén condenados o procesados por haber cometido conductas punibles por causa, con ocasión, o en relación directa o indirecta con el conflicto armado interno. 2. Que no se trate de delitos de lesa humanidad, el genocidio, los graves crímenes de guerra, la toma de rehenes u otra privación grave de la libertad, la tortura, las ejecuciones extrajudiciales, la desaparición forzada, el acceso carnal violento y otras formas de violencia sexual, la sustracción de menores, el desplazamiento forzado, además del reclutamiento de menores conforme a lo establecido en el Estatuto de Roma, salvo que el beneficiario haya estado privado de la libertad un tiempo igualo superior a cinco (5) años, conforme a lo establecido para las sanciones alternativas en la Jurisdicción Especial para la Paz. 3. Que solicite o acepte libre y voluntariamente la intención de acogerse al sistema de la Jurisdicción Especial para la Paz. 4. Que se comprometa, una vez entre a funcionar el Sistema Integral de Verdad, Justicia, Reparación y No Repetición, a contribuir a la verdad, a la no repetición, a la reparación inmaterial de las víctimas, así como atender los requerimientos de los órganos del sistema. Parágrafo 10 Para efectos de los numerales anteriores el interesado suscribirá un acta donde conste su compromiso de sometimiento a la Jurisdicción Especial para la Paz, así como la obligación de informar todo cambio de residencia, no salir del país sin previa autorización de la misma y quedar a disposición de la Jurisdicción Especial para La Paz. 21 En dicha acto deberá dejarse constancia expresa de la autoridad judicial que conoce la causa penal, del estado del proceso, del delito y del radicado de la actuación. Parágrafo $2^{\circ}$. En caso de que el beneficiado sea requerido por el Sistema Integral de Verdad, Justicia, Reparación y No Repetición y no haga presentación o incumpla alguna de las obligaciones contraídas en el compromiso, se le revocará la libertad. No habrá lugar a la revocatoria por circunstancias diferentes a las aquí señaladas.

28 Artículo 53. Procedimiento para la libertad transitoria condicionada y anticipada; El Ministerio de Defensa Nacional consolidará los listados de los miembros de la Fuerza Pública que prima facie cumplan con los requisitos para la aplicación de la libertad transitoria condicionada y anticipada. Para la elaboración de los listados se solicitará información a las jurisdicciones penal ordinaria y penal militar, las que deberán dar respuesta en un término máximo de 15 días hábiles. Una vez consolidados los listados serán remitidos al Secretario Ejecutivo de la Jurisdicción Especial para la Paz quien verificará dichos listados o modificará los mismos en caso de creerlo necesario, así como verificará que se haya suscrito el acta de compromiso de que trata el artículo anterior. El Secretario Ejecutivo de la Jurisdicción Especial para la Paz comunicará al funcionario que esté conociendo la causa penal sobre el cumplimiento de los requisitos por parte del beneficiado, para que proceda a otorgar la libertad transitoria condicionada y anticipada a que se refiere el artículo anterior, funcionario quien de manera inmediata adoptará la acción o decisión tendiente a materializar la misma. El incumplimiento de lo aquí dispuesto constituye falta disciplinaria 
dispuesto en el Artículo 19-2 $2^{29}$ de la Ley 1820 de 2016, previa solicitud del interesado, de la defensa, del Ministerio Público o de oficio, según lo establece el Artículo 8-a-1 del Decreto 277 de $2017^{30}$, o el Juez de Ejecución de Penas, según se trate de personas procesadas o condenadas.

El Decreto 277 de 2017 regula la amnistía de iure para personas privadas de la libertad por delitos políticos y delitos conexos con estos, así como el régimen de libertades condicionales para los supuestos del Artículo $35^{31}$ de la Ley 1820 de 2016. Dicha amnistía comporta la libertad inmediata, en el primer evento señalado en el párrafo anterior por preclusión o cesación del procedimiento derivada de la extinción de las acciones penal y civil de acuerdo con el estatuto procesal aplicable. En el segundo, por la extinción de las penas principales y accesorias (Artículos 34 de la Ley 1820 de 2016, 5 y 9 del Decreto 277 de 2017).

\footnotetext{
${ }^{29}$ Artículo 19. Procedimiento para la implementación de la amnistía de iure.

2. Respecto de quienes exista un proceso en curso por los delitos mencionados en los artículos 15 y 16 de la presente ley, la General de la Nación solicitará inmediatamente la preclusión el Juez de Conocimiento competente.

${ }^{30}$ Artículo $8^{\circ}$. Procedimiento. a. Procedimiento para los privados de libertad con procesos en curso: 1 . los procesos en curso por los delitos mencionados en los artículos 15 y 16 de la Ley 1820 de tratándose las personas privadas de la libertad en las actuaciones sometidas a las Leyes 9062004 Y 1098 de 2006, la Fiscalía General de Nación, previa solicitud del interesado, de la del Ministerio Público u oficio y, en caso los adolescentes, de la Defensoría Familia o de oficio, acompañada los soportes que sean del caso y acta compromiso de que trata artículo 7 del presente Decreto, tramitará inmediatamente la preclusión el de conocimiento competente, siguiendo estas reglas: (...)

${ }^{31}$ Artículo 35. Libertad condicionada. A la entrada en vigor de esta ley, las personas a las que se refieren los artículos 15,16 , 17,22 Y 29 de esta ley que se encuentren privadas de la libertad, incluidos los que hubieren sido procesados o condenados por los delitos contemplados en los artículos 23 y 24, quedarán en libertad condicionada siempre que hayan suscrito el acta de compromiso de que trata el artículo siguiente. Parágrafo. Este beneficio no se aplicará a las personas privadas de la libertad por condenas o procesos por delitos que en el momento de la entrada en vigor de la Ley de Amnistía, no les permita la aplicación de amnistía de iure, salvo que acrediten que han permanecido cuando menos 5 años privados de la libertad por esos hechos y se adelante el trámite del acta previsto en el siguiente artículo. En caso de que la privación de la libertad sea menor a 5 años, las personas serán trasladadas a las Zonas Vereda les Transitorias de Normalización (ZVTN), una vez que los miembros de las FARC-EP en proceso de dejación de armas se hayan concentrado en ellas, donde permanecerán privadas de la libertad en las condiciones establecidas en el numeral 7 del artículo $2^{\circ}$ del Decreto 4151 de 2011. Las personas trasladadas permanecerán en dichas ZVrN en situación de privación de la libertad hasta la entrada en funcionamiento de la JEP, momento en el cual quedarán en libertad condicional a disposición de esta jurisdicción, siempre y cuando hayan suscrito el acta de compromiso de que trata el artículo siguiente. La autoridad judicial que esté conociendo el proceso penal aplicará lo previsto en cuanto a la libertad. La Jurisdicción Especial para la Paz podrá revocar la libertad de quienes incumplan alguna de las obligaciones fijadas en el acta formal de compromiso. Si durante la vigencia de la Jurisdicción Especial para la Paz, los beneficiarios de mecanismos de tratamiento penal especial de la presente ley, se rehusaran a cumplir los requerimientos del Tribunal para la Paz para participar en los programas de contribución a la reparación de las víctimas, o a acudir ante la Comisión de Esclarecimiento de la Verdad de la Convivencia y No Repetición, o ante la Unidad de Búsqueda de las Personas dadas por desaparecidas, se les revocará el derecho a que se les apliquen los beneficios de la libertad condicional o las sanciones establecidas en la JEP.
} 
Por otro lado, la Corte manifestó que las amnistía que no son de iure para miembros o colaboradores de las FARC-EP, la decisión corresponde a la Sala de Amnistía e Indulto de la Jurisdicción Especial para la Paz, siempre que los delitos hubieran sido cometidos antes de la entrada en vigor del Acuerdo Final de Paz, así como respecto de las conductas amnistiables estrechamente vinculadas al proceso de dejación de armas, por lo establecido en el Artículo 22 de la Ley 1820 de 2016, según los criterios de conexidad señalados en el artículo 23 de la misma ley (Corte Suprema de Justicia, Auto AP3005, 2017).

En el mismo sentido indicó que pueden acceder a la libertad condicionada los miembros de las FARC-EP, procesados, que figuren en los listados entregados y verificados por el Gobierno Nacional, cuando hayan cumplido al menos 5 años de privación de libertad y la medida de aseguramiento hubiese sido adoptada por delitos respecto de los que no se otorga la amnistía de iure, a propósito de lo establecido en el Artículo $11^{32}$ del Decreto 277 de 2017. También indicó la Corte que la libertad condicionada se dispondrá para quienes se encuentren en los supuestos previstos en los artículos $17^{33}$ de la Ley 1820 de 2016 y $6^{34}$ del Decreto 277 de 2017, que sólo aplican a miembros o colaboradores de las FARC-EP, así como para los que hubiesen

\footnotetext{
${ }^{32}$ Artículo $11^{\circ}$. Procedimiento de acceso a la libertad condicionada en caso de procesados que han cumplido cuando menos cinco (5) años de privación efectiva de libertad por estos hechos.

${ }_{33}$ Artículo $17^{\circ}$. Aplicación de la amnistía de iure para los integrantes de las FARC-EP que no se encuentran privados de la libertad. amnistía de iure se aplicará a los integrantes de que no se encuentren privados de la libertad, cuando el destinatario haya efectuado dejación de armas y figure en listados verificados y acreditados por el Gobierno Nacional.

${ }^{34}$ La providencia judicial condene, procese o investigue por pertenencia o colaboración con las FARC-EP. En este caso, para la decisión sobre la amnistía, sólo se requerirá el aporte del acta de compromiso prevista en el artículo 18 de la Ley 1820 de 2016 o; encuentren en listados entregados por representantes designados dicha organización expresamente ese fin, listados que verificados conforme a lo establecido en Acuerdo Final Paz. Lo anterior aplica aunque la providencia judicial no procese o investigue por pertenencia a las En este para la decisión sobre la aplicación de la amnistía sólo se requerirá allegar funcionario judicial competente, certificación expedida por Alto Comisionado para la Paz en se indique la inclusión beneficiario en dicho listado, además del acta que trata el artículo 18 de Ley 1820 2016, o; 3. sentencia condenatoria indique la pertenencia condenado a las aunque no se condene por un delito político, siempre que el delito por el haya resultado condenado cumpla los requisitos de conexidad establecidos en el artículo 8 de la 1 de 2016, o; 4 . o hayan sido investigados, procesados o condenados por delitos políticos y conexos, cuando se pueda deducir de las investigaciones judiciales, fiscales y disciplinarias, providencias judiciales o por otras evidencias de actuaciones falladas o en curso que fueron investigados o procesados por su presunta pertenencia o colaboración a las FARC.
} 
solicitado la amnistía y esta resulte desestimada (Corte Suprema de Justicia, Auto AP3005, 2017).

Se pronunció esa corporación sobre la Jurisdicción Especial para la Paz, manifestado que se trataba de una justicia especial donde, mediante la aplicación de los tratamientos penales especiales diferenciados previstos en el Acto Legislativo 01 de 2017 y en la Ley 1820 de 2016 (que conducirá en su momento el envío del proceso a la Jurisdicción Especial para la Paz), implica reconocer que tal normatividad se ubica en el marco de la justicia transicional que, como lo ha señalado la Corte Constitucional, ha sido admitida por la comunidad internacional, dado que tiene como supremo objetivo el restablecimiento de la paz interna, pero siempre y cuando se garantice que las violaciones a los derechos fundamentales sean investigadas, enjuiciadas y reparadas, y los autores de las mismas contribuyan a identificar la verdad de los delitos cometidos y reciban algún tipo de sanción. (Corte Suprema de Justicia, Auto AP3004, 2017)

Según la Corte, esas exigencias se cumplen en los trámites que adelanta la Jurisdicción Especial para la Paz, pues uno de los principios que funda su creación es el de la satisfacción de los derechos de las víctimas a la Verdad, Justicia, Reparación y No Repetición, para cuyo propósito el Artículo 22 del Acto Legislativo 01 de 2017 le impone a la referida jurisdicción en los casos de los agentes del Estado y, particularmente, de los miembros de la fuerza pública, respetar las obligaciones internacionales de investigación, juzgamiento y sanción. Esto significa que no le será suficiente, para adoptar sus decisiones, con la versión que ofrezca el interesado sino que estará obligada a verificar la información que éste suministre. (Corte Suprema de Justicia, Auto AP3004, 2017)

La Corte Suprema de Justicia menciona que el Acto Legislativo 01 del 4 de abril de 2017, incorporado a la Constitución Política a partir de esa fecha, dispuso en su Artículo transitorio 19, 
la extradición para el caso específico del posconflicto, en el sentido de que no se podrá conceder la extradición ni tomar medidas de aseguramiento con fines de extradición respecto de hechos o conductas objeto de este Sistema y en particular de la Jurisdicción Especial para la Paz, ocasionados u ocurridos durante el conflicto armado interno o con ocasión de este hasta la finalización del mismo, trátese de delitos amnistiables o de delitos no amnistiables, y en especial por ningún delito político, de rebelión o conexo con los anteriores, ya hubieran sido cometidos dentro o fuera de Colombia.

Dicha garantía de no extradición alcanza a todos los integrantes de las FARC-EP y a personas acusadas de formar parte de dicha organización, por cualquier conducta realizada con anterioridad a la firma del acuerdo final, para aquellas personas que se sometan al SIVJRNR. Claramente se advierte que con tal norma se introdujo al ordenamiento jurídico colombiano la prohibición de conceder la extradición y adoptar "medidas de aseguramiento" con ese fin, respecto de los integrantes de las FARC-EP que cometieron conductas delictivas durante el conflicto armado interno o con ocasión de este, con anterioridad a la firma del Acuerdo Final de Paz (Corte Suprema de Justicia, Auto AP3393-2017, 2017).

Con respecto a la libertad transitoria y condicionada, se indicó por parte de la Corte Suprema colombiana que es un beneficio temporal del Sistema Integral de Verdad, Justicia, Reparación y No Repetición, expresión del tratamiento simétrico en algunos aspectos, diferenciado en otros, pero siempre equitativo, equilibrado y simultáneo, propio de la Jurisdicción Especial para la Paz, previsto para los procesados o condenados privados de la libertad señalados de cometer conductas punibles por causa, con ocasión o en relación directa o indirecta con el conflicto armado interno. 
La Corte consideró sobre la libertad transitoria y condicionada para las FARC-EP y los agentes estatales que, con fundamento en el Artículo 51 de la Ley 1820 de 2016, conforme proceda la libertad transitoria deben concurrir los siguientes requisitos: (i) que el beneficiario acredite la condición de agente del Estado para el momento de los hechos, (ii) que efectivamente se encuentre privado de la libertad, bien sea en la condición de procesado o condenado a la fecha de la entrada en vigencia de la Ley en cita; (iii) que los delitos atribuidos correspondan a hechos sucedidos antes de la entrada en vigor del Acuerdo Final para la Terminación del Conflicto y la Construcción de una Paz Estable y Duradera del 24 de noviembre de 2016; (iv) que los mismos se hayan cometido con ocasión, por causa, o en relación directa o indirecta con el conflicto armado; (v) que la privación de la libertad se haya decretado por delitos distintos a los de lesa humanidad, genocidio, graves crímenes de guerra, es decir, los señalados en el Capítulo Único del Título II del Libro Segundo del Código Penal, Artículos 135 a 164³5, según lo establecido en el Artículo 23 de la Ley 1820, como: la toma de rehenes u otras privaciones graves de la libertad, tortura, ejecuciones extrajudiciales, desaparición forzada, acceso carnal violento y otras formas de violencia sexual, sustracción de menores, desplazamiento forzado y reclutamiento de menores. Todo lo anterior en los términos del Estatuto de Roma. O, (vi) que habiéndose decretado la privación de la libertad por alguna de las conductas punibles antes señaladas, el

\footnotetext{
35 Delitos contra personas y bienes protegidos por el Derecho Internacional Humanitario: Artículo 135. Homicidio en persona protegida. Artículo 136. Lesiones en persona protegida. Artículo 137. Tortura en persona protegida. Artículo 138. Acceso carnal violento en persona protegida. Artículo 139. Actos sexuales violentos en persona protegida Prostitución forzada o esclavitud sexual. Artículo 142. Utilización de medios y métodos de guerra ilícitos. Artículo 143. Perfidia. Artículo 144. Actos de terrorismo. Artículo 145. Actos de barbarie. Artículo 146. Tratos inhumanos y degradantes y experimentos biológicos en persona protegida. Artículo 147. Actos de discriminación racial. Artículo 148. Toma de rehenes. Artículo 149. Detención ilegal y privación del debido proceso. Artículo 150. Constreñimiento a apoyo bélico. Artículo 151. Despojo en el campo de batalla. Artículo 152. Omisión de medidas de socorro y asistencia humanitaria. Artículo 153. Obstaculización de tareas sanitarias y humanitarias. Artículo 154. Destrucción y apropiación de bienes protegidos. Artículo 155. Destrucción de bienes e instalaciones de carácter sanitario. Artículo 156. Destrucción o utilización ilícita de bienes culturales y de lugares de culto. Artículo 157. Ataque contra obras e instalaciones que contienen fuerzas peligrosas. Artículo 158. Represalias. Artículo 159. Deportación, expulsión, traslado o desplazamiento forzado de población civil. Artículo 160. Atentados a la subsistencia y devastación. Artículo 161. Omisión de medidas de protección a la población civil. Artículo 162. Reclutamiento ilícito. Artículo 163. Exacción o contribuciones arbitrarias. Artículo 164. Destrucción del medio ambiente.
} 
solicitante acredite haber estado detenido efectivamente por un tiempo igual o superior a 5 años (Corte Suprema de Justicia, Auto AP3947, 2017).

A su vez, se requiere que (vii) suscriba acta de compromiso en la que manifieste libre y voluntariamente, ante el Secretario Ejecutivo de la Jurisdicción Especial para la Paz, la intención de acogerse a esta jurisdicción y, a su vez, que no saldrá del país sin previa autorización de la misma, y que informará sobre todo cambio de domicilio. En el documento también se identificará la autoridad judicial que conoce del proceso, el estado en que éste se encuentra, el delito por el cual se procede y el número del radicado (Corte Suprema de Justicia, Auto AP3947, 2017).

En el mismo orden de ideas, se deberá (viii) adquirir el compromiso por escrito, de que una vez entre a funcionar el Sistema Integral de Verdad, Justicia, Reparación y No Repetición, el beneficiado con la libertad transitoria condicionada y anticipada contribuirá con la verdad, la no repetición, la reparación inmaterial de las víctimas y que atenderá los requerimientos de los órganos del sistema en cita (Corte Suprema de Justicia, Auto AP3947, 2017).

Por otra parte, se advirtió sobre la suspensión de la ejecución de las órdenes de captura del artículo $6^{\circ}$ del Decreto 706 de 2017, que es un beneficio de carácter temporal previsto en el SIVJRNR, que se aplica en la Jurisdicción Especial para la Paz y procede en cualquier estado de la actuación -investigación, juzgamiento y ejecución de la sentencia-; esto es, tanto para personas procesadas como condenadas, al margen de la motivación que haya dado lugar a la orden, vinculación al proceso, cumplimiento de la medida de aseguramiento o ejecución de la sentencia (Corte Suprema de Justicia, AutoAP688, 2017). 
Igualmente, que tiende a facilitar el sometimiento de los miembros de la Fuerza Pública que han decidido acogerse a la jurisdicción especial y están en libertad señalados de cometer conductas punibles por causa, con ocasión o en relación directa o indirecta con el conflicto armado interno, sobre quienes recaen requerimientos de aprehensión. Se precisó que la oportunidad para presentar la petición de suspensión de la ejecución de las órdenes de captura contra miembros de la Fuerza Pública se extiende a que las mismas estén vigentes y no se hayan hecho efectivas, siempre y cuando hayan sido proferidas en procesos seguidos por la comisión de conductas punibles antes de la vigencia del clausulado del Acuerdo Final para la Paz, por causa, o en relación directa o indirecta con el conflicto armado (Corte Suprema de Justicia, AutoAP688, 2017).

Por otro lado, con respecto de los casos de conductas reprochables a agentes del Estado, aquellas suspensiones de la pena o la cesación de la acción penal serán para miembros de la Fuerza Pública. Requisitos: haber cometido conductas punibles por causa, con ocasión o en relación directa o indirecta con el conflicto armado y homicidio en persona protegida (caso falso positivo) (Corte Suprema de Justicia, AutoAP688, 2017).

Sobre la competencia de la justicia ordinaria, la Corte afirmó que es competente para definir las controversias planteadas de acuerdo la Ley 906 de 2004; sin embargo, tratándose de delitos acontecidos como consecuencia de actos perpetrados por las FARC-EP, la competencia para definir la cuestión debe ser radicada en la Sala de Definición de Situaciones Jurídicas de la Jurisdicción Especializada para la Paz, a petición del interesado o de oficio, y una vez en firme la resolución que concede el mecanismo, será remitida a la autoridad judicial que esté conociendo de la causa penal, para que dé cumplimiento a la misma (Corte Suprema de Justicia, Auto AP880, 2017). 
No obstante, ratificando la línea del Alto Tribunal Penal, mientras se decide lo anterior, a los agentes del Estado y a los integrantes de las FARC-EP, dependiendo el caso, les será concedida la libertad transitoria condicionada y anticipada, siempre que al momento de entrar en vigencia la Ley 1820 de 2016 estén detenidos o condenados y acepten su sometimiento a la Sala de Definición de Situaciones Jurídicas de la Jurisdicción Especial para la Paz, con el fin de acogerse a la renuncia de la persecución penal (Corte Suprema de Justicia, Auto AP880, 2017).

Finalmente, en el Decreto 522 de 2018 expedido por el Gobierno Nacional, se adiciona el Decreto 1069 de 2015, por medio del cual se expide el Decreto Único Reglamentario del Sector Justicia, y se reglamenta parcialmente la Ley 1820 de 2016, se reglamentan las competencias y funciones de la Sala de Amnistía o Indulto y de la Sala de Definición de Situaciones Jurídicas de la JEP, teniendo en cuenta que es deber de la JEP garantizar con celeridad los derechos de las víctimas a la Justicia, la Verdad, la Reparación, la No repetición, contribuir al logro de una Paz estable y duradera, y adoptar decisiones que otorguen plena seguridad jurídica a quienes participaron de manera directa o indirecta en el conflicto armado interno, y solo a través del reparto de solicitudes a estas secciones de la JEP se pueden garantizar los derechos de las víctimas y garantías de los victimarios. Entonces, dicha norma reglamentaria es expedida en búsqueda de la necesidad de reglamentar la Ley 1820 de 2016 en lo concerniente a las solicitudes de amnistía que sean presentadas a la Jurisdicción Especial para la Paz (Congreso de la República de Colombia, 2018).

En último lugar, se resalta lo dispuesto en el Artículo 1 del Decreto 522, sobre las solicitudes de amnistía de que trata la Ley 1820 de 2016, Artículo 18, las cuales se deberán presentar a la Sala de Amnistía e Indulto de la Jurisdicción Especial para la Paz aportando para ello: (i) la certificación individual de dejación de armas expedida por la Misión de Verificación 
de la ONU en Colombia; (ii) la certificación sobre pertenencia a las Fuerzas Armadas Revolucionarias de Colombia (FARC-EP) expedida por la Oficina del Alto Comisionado para la Paz o una providencia judicial que le condene, procese o investigue por pertenencia o colaboración con las FARC-EP (Congreso de la República de Colombia, 2018).

Cuando se trate de personas privadas de la libertad, la solicitud de amnistía deberá aportar: (i) un acta en la que se comprometa a no volver a utilizar las armas para atacar el régimen constitucional y legal vigente; (ii) la certificación sobre su pertenencia a las Fuerzas Armadas Revolucionarias de Colombia (FARC-EP) expedida por la Oficina del Alto Comisionado para la Paz o una providencia judicial que le condene, procese o investigue por pertenencia o colaboración con las FARC-EP (Congreso de la República de Colombia, 2018).

Las solicitudes de amnistía de las personas deberán tener las siguiente condiciones: (i) que la providencia judicial lo condene, procese o investigue por pertenencia o colaboración con las FARC-EP; (ii) que sean integrantes de las FARC-EP tras la entrada en vigencia del Acuerdo Final de Paz con el Gobierno nacional, de conformidad con los listados entregados por representantes designados por dicha organización expresamente para ese fin, listados que serán verificados conforme a lo establecido en el Acuerdo Final de Paz. Lo anterior aplica aunque la providencia judicial no condene, procese o investigue por pertenencia a las FARC-EP (Congreso de la República de Colombia, 2018).

Dichas condiciones de que tratan los numerales 1 y 2 del artículo 17 de la Ley 1820 de 2016, para las personas que se presenten ante la Sala de Amnistía e Indulto, se resolverán en el término de tres (3) meses a que se refiere el artículo 21 de la Ley 1820 de 2016, conforme a la normatividad interna definida por la Jurisdicción Especial para la Paz y siempre que el solicitante 
haya concluido el proceso de dejación de armas de que trata el artículo 18 de la citada ley. Si la solicitud de amnistía es presentada sin cumplir los requisitos establecidos en esta Sección, se podrá requerir al solicitante para que los complete. (Congreso de la República de Colombia, 2018)

Finalmente, en uno de los últimos pronunciamientos sobre la Ley de Amnistía la Corte Constitucional, quien realizó el control automático y definitivo de la ley 1820 de 2016, la declara exequible en la mayor parte de sus normas, salvo en algunos aspectos que fueron retirados del mundo jurídico por inexequibilidad o se condicionó la exequibilidad parcialmente.

En esa sentencia se consideró de manera general que la Ley 1820 de 2016 es una pieza esencial en la implementación del Acuerdo Final, pues las amnistías, indultos y tratamientos penales especiales representan uno de los principales mecanismos para la reconciliación, para la finalización del conflicto armado, porque constituyen instituciones indispensables para las víctimas, de manera que se armonizan con sus derechos a la verdad, la justicia, la reparación y la no repetición, al convertirse en garantía de estabilidad de la paz (Corte Constitucional, Sentencia C-007, 2018).

Las conclusiones que deja este capítulo se refieren específicamente a la relación de la amnistía y el indulto con la repartición de las víctimas que está enmarcada con la garantía de estos a obtener Justicia, Verdad, Reparación y No Repetición, involucrando a la Jurisdicción Especial para la Paz como el gran encargado de reparar a las víctimas. Lo precisado, por cuando el marco de justicia transicional demarcado por el Acuerdo y las normas que desarrollan la amnistía y el indulto están enfocados a la reparación de las víctimas, sin obligar a un orden de qué es lo que se da primero, la reparación de las víctimas o la seguridad jurídica de los 
victimarios, pues lo que se busca en el fondo de todas las regulaciones es la restauración de la sociedad.

Observamos que no es el fin último de la Paz la concesión de beneficios penales a los integrantes de los grupos al margen de la ley que crean la desestabilización de las instituciones; mientras que es su objetivo la construcción de la institucionalidad y la inclusión social. De ello se deriva la necesidad de la concesión de ciertos alivios penales sometidos específicamente a contribuir con la verdad y el esclarecimiento de lo ocurrido, como una decisión política que sí tiene como fin último la paz estable y duradera, a través de la reparación de las víctimas que somos todos aquellos integrantes de un Estado en guerra originada por la desigualdad social. 


\section{SEGUNDA PARTE}

\section{PROCESO DE JUSTICIA TRANSICIONAL: JUSTIFICACIÓN DE LAS AMNISTÍAS E INDULTOS PARA GARANTIZAR LA VERDAD DE LAS VÍCTIMAS Y UNA PAZ ESTABLE Y DURADERA}

Esta parte del proyecto investigativo se dirige a concretar los argumentos; es decir, lo que buscamos con los siguientes capítulos es establecer que en el marco de justicia utilizado para la reconciliación nacional, luego de un conflicto armado con grupos ilegales o una dictadura donde se hayan cometido graves crímenes por el Estado, es totalmente válida la utilización de amnistías e indultos como instrumentos políticos para la obtención de la paz, la cual incluye la protección de los derechos de las víctimas y, sobre todo, el derecho a la verdad que es condición sinecuanum para el otorgamiento de dichas prerrogativas.

Dicho de otro modo, lo que se quiere con esta parte de la investigación es determinar la forma en que las amnistías y los indultos constituyen instituciones idóneas, en el marco de la justicia transicional, para conseguir la reconciliación nacional y terminar el conflicto armado interno, así como establecer que el derecho a la verdad de las víctimas del conflicto armado colombiano legitima las amnistías e indultos. 


\section{CAPÍTULO TERCERO}

\section{JUSTICIA TRANSICIONAL PARA LA CONSTRUCCIÓN DE UNA PAZ ESTABLE Y DURADERA}

\section{ACERCAMIENTO AL CONCEPTO DE JUSTICIA Y SUS CLASES}

El concepto de justicia se viene desarrollando desde siglos atrás por filósofos de amplio reconocimiento como Aristóteles (384 a.C. - 322 a.C.), quien consideró que la justicia debe ser definida como la virtud moral del ser humano. Específicamente, llamó justicia a "aquel hábito que dispone a los hombres a hacer cosas justas y por el cual obran justamente y quieren lo justo", o, como la costumbre mediante la cual "se causan: primero, una inclinación hacia los actos de justicia, según la cual decimos que el hombre es ejecutor de lo justo; segundo, la operación justa; y tercero, que el hombre quiera obrar lo justo” (Contreras, 2012, p. 65).

Según el profesor Álvarez en su escrito Justicia, Derecho e Igualdad, Aristóteles considera que la justicia en sentido estricto está orientada a la distribución de los beneficios que reciben los ciudadanos dentro del Estado, la cual se divide en dos, así: "1. General. Consiste en el cumplimiento de las leyes naturales —ordena y va del todo a las partes_” (...) “2. Particular. Consiste en dar a cada uno lo que le corresponde en las circunstancias concretas principio de ponderación —” (Durango Álvarez, 2011, p. 38).

Así mismo, mencionó que la justicia, según Aristóteles, puede ser:

(i) Conmutativa: cuando existe una relación de individuo a individuo, igualdad aritmética en tanto trata de establecer la igualdad en los intercambios con un mismo valor, en el entendido que pretende dejar las cosas como estaban antes; 
(ii) Distributiva: cuando se refiere a la relación entre el Estado y los individuos en el reparto de bienes, cargas, méritos, atributos, derechos, deberes y ganancias. El criterio de reparto de la igualdad debe ser proporcional según la norma pública que lo aplique; y,

(iii) Correctiva: la considera judicial o de "ojo por ojo". En esta, se refiere a la proporción entre el delito y su correspondiente castigo o sanción. (Durango Álvarez, 2011, p. 36).

Por lo anterior, se puede inferir que ese concepto de justicia es un límite impuesto a los actos del poder legislativo, en tanto establece que un mismo órgano no puede modificar arbitrariamente el sentido de sus decisiones en casos sustancialmente iguales. Dicho ejercicio del poder comporta las siguientes características (Durango Álvarez, 2011, p. 36):

1) Un estándar de conducta consistente en tratar los casos y personas iguales de manera igual, lo que expresa un deber de no variar la decisión tomada de manera arbitraria. Ejemplo: el caso individual C1 es igual al caso individual C2 en aquellos casos que así lo requieran — tratar igual lo que es igual—. Esta concepción formal se asocia a la idea de la justicia distributiva de recursos como la renta, educación, salud y derechos, entre otros.

2) Un criterio de excepción en la igualdad, esto es, analizar si los casos ameritan ser considerados iguales y cuándo no. Este mecanismo es planteado como 'acción positiva', entendiendo por ésta, los mecanismos especiales que busca nivelar individuos o grupos desaventajados social e históricamente por parte de quien ostenta el poder y por quienes toman decisiones. La acción positiva comporta una equiparación en la igualdad para quien se encuentra excluido por la norma. (...) 
Por ello, el profesor Álvarez reseña oportunamente que "las pretensiones sobre la justicia marcan una relación inseparable entre lo igualitario, lo equitativo y lo imparcial, que conllevan necesariamente la búsqueda y equiparación de los grupos e individuos excluidos socialmente", de tal forma que el concepto de justicia "hace referencia a las instituciones sociales y a la forma como estas ejercitan mecanismos concretos para paliar la desigualdad social” (Durango Álvarez, 2011, p. 36).

No sin menos importancia debe definirse el concepto de justicia distributiva, donde tomamos como referencia al profesor Rawls quien, en su tratado Teoría de la Justicia, indica (Rawls, 1995, págs. 67-68):

Primero: cada persona ha de tener un derecho igual al esquema más extenso de libertades básicas que sea compatible con un esquema semejante de libertades para los demás; y segundo: las desigualdades sociales y económicas habrán de ser conformadas de modo tal que a la vez que: a) se espere razonablemente que sean ventajosas para todos, b) se vinculen a empleos y cargos asequibles para todos.

También define que la justicia, según su objeto, "es la estructura básica de la sociedad o, más exactamente, el modo en que las grandes instituciones sociales distribuyen los derechos y deberes fundamentales y determinan la división de las ventajas provenientes de la cooperación social” (Rawls, 1995, p. 20).

Rawls propone una teoría ideal de la justicia que reside en la posibilidad de evaluar la gravedad de las imperfecciones reales y establecer el mejor modo de acercarse a ese ideal. Dicha teoría es una reacción contra el relativismo y el escepticismo ético, que niegan la posibilidad de afirmar la verdad o falsedad de las afirmaciones sobre lo justo o lo correcto, de tal forma que 
"marcó un renacimiento del realismo moral, según el cual la argumentación en materia de justicia es una actividad fructífera, en la que es posible distinguir mejores y peores respuestas" (Caballero García, 2006, P. 21).

Ahora bien, otro concepto de justicia de gran importancia para esta investigación es el de justicia restaurativa. Ha sido desarrollado por las Naciones Unidas ampliamente, en virtud de la necesidad de regular los procesos de reparación de las víctimas de trasgresiones a los Derechos Humanos. En primer lugar, definió el proceso restaurativo como aquel en que participa conjuntamente de forma activa en la resolución de las cuestiones derivadas del delito la víctima, el delincuente y cualquier persona afectada por un delito (Naciones Unidas Contra la Droga y el Delito, 2006, págs. 5-7).

Seguidamente, ese órgano internacional consideró que la justicia restaurativa "es un proceso para resolver el problema de la delincuencia, enfocándose en la compensación del daño a las víctimas, haciendo a los delincuentes responsables de sus acciones y también, a menudo, involucrando a la comunidad en la resolución del conflicto" (Naciones Unidas Contra la Droga y el Delito, 2006, págs. 5-7).

De otra parte, se plantea el concepto de justicia aplicada, sobre todo, en los procesos penales, denominada: justicia retributiva, que según la Corte Constitucional se relaciona con el castigo penal proporcional a la conducta del delincuente. Desde el punto de vista del Derecho Internacional de los Derechos Humanos, existe la "obligación del Estado de de investigar, sancionar y juzgar las graves violaciones de los derechos humanos que exige una concepción de la soberanía compatible con el carácter universal de los derechos humanos" (Corte Constitucional, Sentencia C- 007, 2018). 
En ese orden de las cosas, la justicia retributiva surge de las normas internas de derecho penal, pero se relaciona también con las obligaciones internacionales en materia de Derecho Internacional de los Derechos Humanos, Derecho Internacional Humanitario y Derecho Penal Internacional, que permiten el castigo directo a los responsables de las más graves violaciones a los derechos y las libertades de las personas, los derechos humanos y de las graves infracciones (Corte Constitucional, Sentencia C- 007, 2018).

Este deber, sin embargo, es percibido en ocasiones como un obstáculo o, al menos, un desafío para la materialización de un acuerdo de paz, dado que los participantes directos en las hostilidades rehusarían una negociación que tenga como único resultado un castigo particularmente severo. En efecto, este desafío es enorme cuando, como ocurre en Colombia, ha existido un conflicto marcado por su gran complejidad, duración y diversidad de actores (Corte Constitucional, Sentencia C- 007, 2018).

Finalmente, vendría al caso definir el concepto de justicia transicional. Sin embargo, como el presente texto aborda in extenso dicho tema, ese concepto será objeto de desarrollo en títulos siguientes.

\section{APROXIMACIONES AL CONCEPTO DE JUSTICIA TRANSICIONAL}

Con el fin de desarrollar este capítulo, es de suma importancia acercar al lector al concepto de justicia transicional, para lo cual se tendrá en cuenta lo manifestado en la materia por la comunidad internacional a través de las Naciones Unidas, dado que el concepto se desarrolla de forma general y en el marco del Derecho Internacional Humanitario y de los Derechos Humanos. 
En ese sentido, como primer intento de definición de justicia transicional, podemos encontrar lo considerado por las Naciones Unidas, al considerar que son los elementos, procesos y mecanismos "asociados con los intentos de una sociedad por resolver los problemas derivados de un pasado de abusos a gran escala, a fin de que los responsables rindan cuentas de sus actos, servir a la justicia y lograr la reconciliación”" (Naciones Unidas, 2004).

También, en materia doctrinal encontramos que se ha definido la justicia trancisional como la situación en la que se abarcan situaciones de procesos de paz de un conflicto en curso o de una democracia formal (Steiner \& Ambos, 2008, p. 8), teniendo en cuenta que las herramientas comunes no son idóneas para resolver los problemas derivados de los crímenes de guerra o de lesa humanidad ocurridos en el marco de un conflicto armado, pues han dejado millones de desplazados, miles de secuestrados y desaparecidos (víctimas) y, así mismo, indemnizaciones reclamadas en busca de una reparación.

Finalmente, cabe resaltar que existe una gran variedad de instrumentos para lidiar con el pasado (dirigidos a prevenir que las atrocidades y conflictos se repitan, y con el fin de brindar un parámetro de justicia transicional consistente), los cuales se caracterizan por lo siguiente: (i) la diversidad de acciones penales a través de tribunales nacionales e internacionales; (ii) la búsqueda de la verdad, a través de la exposición de las violaciones a los Derechos Humanos a través de comisiones de la verdad; (iii) la reparación de las víctimas a través de rehabilitación, restitución y compensación económica; (iv) las reformas institucionales en materia de justicia, política, entre otros; y, (v) las tareas de conmemoración mediante lugares conmemorativos y museos (Romeike, 2016, págs.6-7). 


\section{JUSTICIA TRANSICIONAL EN ALEMANIA Y BRASIL: LAS EXPERIENCIAS DE OTROAS PAISES}

Definidos los conceptos básicos para comprender qué es Justicia, qué es lo que busca, y cuál es la finalidad de la justicia transicional, es indispensable desarrollar un análisis de los procesos de reconciliación nacional en Alemania y Brasil, ya que dan un acercamiento a las necesidades en materia de justicia y derechos de las víctimas, que ha dejado como experiencia la implementación de la justicia transicional en dichos países.

\subsection{Justicia Transicional en Alemania}

La justicia transicional alemana, según la Academia Internacional de los Principios de Núremberg, se divide en dos etapas conflictivas de esa nación: la primera, se refiere a la justicia transicional después de 1945, sobre la superación de la dictadura nacionalsocialista; y, la segunda, a la justicia transicional después de 1990, referente a la superación de la dictadura del Partido Socialista Unificado de Alemania (SED).

Luego de la segunda guerra mundial, donde se infundió un régimen de terror en muchos países europeos, se había perseguido a enemigos sociales y políticos, mientras que personas con minusvalías físicas y psicológicas, pacientes psiquiátricos y, sobre todo, la población judía, fueron llevados a campos de concentración, esclavizados, torturados y asesinados, por lo que, con la rendición incondicional de las Fuerzas armadas del régimen Nazi, se consolidaron los nuevos estados alemanes, la República Federal Alemana (RFA) y la República Democrática Alemana (RDA) (Romeike, 2016, págs. 8-9). 
Por esa razón, el nuevo gobierno nacional alemán inició un proceso de justicia transicional donde primaron las reparaciones, la restitución y la compensación a las víctimas y la concesión de amnistías generales, dadas las reclamaciones por parte de las potencias victoriosas, por lo que se creó una política de reparación para la devolución de patrimonio robado y expropiado. También, se conformó una política de documentación, amonestación y conmemoración, la reeducación y educación cívica en la zona de ocupación occidental, la reforma antifascista-democrática en la franja de ocupación soviética y la cultura conmemorativa en el Este y Oeste de Alemania (Romeike, 2016).

Por otro lado, después del derrumbamiento del régimen del SED (Partido Socialista Unificado de Alemania), considerado como una de las dictaduras del pueblo alemán, y la reunificación de los dos estados alemanes entre 1989 y 1990, el país se enfrentó a un proceso sustancial de transformación. La superación empezó por la Alemania Oriental, que tuvo un papel importante en la reunificación e integración estatal en el derecho internacional, aunque solamente resultó en una ampliación territorial de la República Federal Alemana (RFA) (Romeike, 2016, p. 44). En esta etapa hubo una considerable diferencia en el tipo y la cantidad de los crímenes cometidos en ambas dictadura; la RDA no había avanzado mediante una guerra de conquista, ni había cometido millones de asesinatos en masa; empero, el régimen del SED había lesionado masiva y sistemáticamente los Derechos Humanos en favor de la legitimación de su poder y la imposición de su propia ideología (Romeike, 2016, p. 45-46).

La cuestión de la culpabilidad fue diferente a la de 1945, porque la cantidad de criminales era menor; además, la solidaridad de la sociedad con las víctimas del régimen del SED facilitó la superación de las injusticias acaecidas (Romeike, 2016, págs. 45-46). En contraste, el proceso de justicia transicional no fue muy diferente al de 1945, pues con base a las experiencias se tomaron 
las fórmulas de reparación a las víctimas y de juzgamiento para los responsables de los crímenes cometidos que fueron utilizadas para la terminación del régimen nazi (Romeike, 2016p. 46).

\subsection{Justicia Transicional en Brasil}

El proceso de justicia transicional en Brasil se caracteriza por haber sido una transición de la dictadura a la democracia (1964 a 1985) por la presión popular de grupos como el Partido Comunista de Brasil, la crisis de la economía y la falta de apoyo internacional, lo que hace que los últimos presidentes del régimen, Ernesto Geisel (1974-1979) y Joao Baptista de Oliveira Figueiredo, den el paso hacia la democracia (Gómez de la Torre, 2017, págs. 25-26).

En un contexto de desinformación de la opinión pública, con el fin de silenciar los actos de lesa humanidad que había cometido la dictadura de la época de forma sistemática en contra de un grupo disidente, el grupo armado populista denominado FOGUERA, organizado en virtud de la inconformidad y de las desigualdades sociales, fue aniquilado en Araguai por el ejército de la dictadura militar de la época (1969-1974) (Gómez de la Torre, 2017, págs. 32-39).

Para el año de 1978 se crea el Comité Brasileño pro Amnistía con el fin de otorgarles a los actores de la aniquilación del grupo disidente y otros, como los terroristas, amplias amnistías sobre graves crímenes cometidos por los agentes del estado y al margen de la ley, de manera general e irrestricta (Gómez de la Torre, 2017, p. 47). Finalmente, en el marco de la justicia transicional se estudió una ley donde tuvieron participación en el debate la sociedad, el gobierno y las Fuerzas Armadas que no tomaron las ideas del Movimiento pro Amnistía. La ley de 1979 permitió el retorno de muchos exiliados y anuló sanciones administrativas; pero, en el caso de las consecuencias penales, era una amnistía para los torturadores y no tenía en cuenta la reparación de los torturados (Gómez de la Torre, 2017, págs. 48-49). 
Para 1985 se aprobó una enmienda constitucional que se refirió a la amnistía para los servidores públicos de la administración y para los militares, aplicable para quienes hubieran cometido delitos políticos y los conexos con ellos (Gómez de la Torre, 2017, p. 50).

Con la constitución de 1988 se constituye un nuevo marco político y jurídico que regularía las actuaciones de los militares y cuerpos de seguridad, donde se excluye expresamente la tortura de las amnistías e indultos (Gómez de la Torre, 2017, págs. 54-55).

Posteriormente, desde la década del 90 en adelante, en virtud de las demandas de los familiares de las víctimas, inicia el fortalecimiento de las formas y acciones para repararlos, por lo que en los gobiernos de Henrique Cardoso (1995-2002), Lula da Silva (2003-2011) y Dilma Roussef (2011-2016) se dieron pasos en pro de la justicia transicional. En esos gobiernos se suscribió un programa de justicia transicional, se iniciaron las investigaciones en forma de los hechos ocurridos, se creó la Ley de los Desaparecidos y se establecieron indemnizaciones. El logro más grande fue la contribución relevante del reconocimiento oficial de la verdad de las torturas y de las muertes llevadas a cabo por quienes formaban parte del Estado, además de la localización, reconocimiento e identificación de cuerpos (Gómez de la Torre, 2017, págs. 64-69).

En el año 2010 la Corte Interamericana de Derecho Humanos profiere una extensa y documentada sentencia donde condena al Estado de Brasil en el caso de la guerrilla de Araguai vs. Brasil, donde se analizó la responsabilidad del Estado por las desapariciones forzadas de guerrilleros y campesinos durante el conflicto mencionado y las consecuencias del derecho a la verdad proyectadas sobre la información de los posibles enterramientos de los desaparecidos (Corte Interamericana de Derechos Humanos, “Guerrilha do Araguaia” Vs. Brasil, 2010). 
Es del caso finalizar mencionando que la transición por transformación del Estado brasilero se ha caracterizado por la búsqueda de la investigación de las graves violaciones de los Derechos Humanos y el enjuiciamiento de los máximos responsables, que estuvieron revestidas de dificultades políticas y jurídicas, pero con el paso del tiempo se han venido implementando medidas de reparación y otras sobre justicia que complementan un proceso que ha hecho parte de la historia de Brasil.

\section{JUSTICIA TRANSICIONAL EN COLOMBIA Y FINES DE LAS SANCIONES A IMPONER}

\subsection{Desarrollo del concepto de justicia transicional en Colombia}

En la doctrina colombiana la justicia transicional se ha definido como los procesos a través de los cuales se realizan transformaciones radicales de un orden social y político, bien sea por el paso de un régimen dictatorial o uno democrático, o por la finalización de un conflicto interno y la consiguiente consecuencia de la paz (Uprimny Yepes, Saffon Sanín, Botero Marino, \& Restrepo Saldarriaga, 2006, p. 19).

Por su parte, la jurisprudencia de la Corte Constitucional ha definido la justicia transicional como una nueva modalidad de impartir justicia que modifica los principios que gobiernan el ejercicio de la administración de justicia, porque sus fines se entrelazan con la terminación del conflicto, el reconocimiento de las víctimas, la reconciliación, el fortalecimiento de la democracia y la obtención de una paz estable y duradera (Corte Constitucional, 2013). En el mismo sentido, en reiteradas decisiones de la Corte se han desarrollado juicios sobre la justicia transicional, pero especialmente con motivo del Acto Legislativo 01 de 2012 (por medio del cual se establecen instrumentos jurídicos de justicia transicional), en Sentencia C-579/13, 2013, así: 
Constató que la reforma introducida mediante el Acto Legislativo demandado partió de la base de que para lograr una paz estable y duradera es necesario adoptar medidas de justicia transicional. En ese sentido dispuso: (i) la creación de criterios de selección y priorización que permitan centrar esfuerzos en la investigación penal de los máximos responsables de los delitos de lesa humanidad, genocidio o crímenes de guerra cometidos de manera sistemática; (ii) la renuncia condicionada a la persecución judicial penal y; (iii) la suspensión condicional de la ejecución de la pena, la aplicación de penas alternativas, de sanciones extrajudiciales y de modalidades especiales de cumplimiento.

Igualmente, en los términos de la jurisprudencia referida,

la justicia transicional implica la articulación de una serie de medidas, judiciales o extrajudiciales, y puede abarcar el enjuiciamiento de personas, el resarcimiento, la búsqueda de la verdad, la reforma institucional, la investigación de antecedentes, la remoción del cargo o combinaciones de todas las anteriores, tal como ha reconocido el propio Consejo de Seguridad de las Naciones Unidas.

Esta clase de justicia excepcional se justifica en la Constitución Política, teniendo en cuenta lo dispuesto en Sentencia C-379/16, la cual considera que:

la paz es un objetivo de primer orden dentro del modelo de organización política adoptado por la Constitución. Para ello, se reconoce la triple condición de la paz como derecho, deber y valor fundante de dicho modelo, lo cual conlleva a obligaciones directas en, al menos, tres aspectos definidos: (i) un deber estatal de diseño e implementación de acciones, normativas y de política pública, dirigidas a la 
superación del conflicto armado y, en general, el logro de la convivencia pacífica; (ii) un deber social de preferir a la solución pacífica como mecanismo exclusivo y constitucionalmente admisible de resolución de las controversias; y (iii) el logro progresivo de la plena vigencia de los derechos fundamentales, lo cual es un presupuesto tanto para la paz como para la vigencia del orden democrático, concebido desde una perspectiva material (Corte Constitucional, 2016).

Por otro lado, una sociedad que ha padecido un conflicto armado interno tiene que afrontar la transición cuando se pone fin a las acciones armadas que llevaron a privilegiar la violencia sobre la razón; de tal forma que, cuando la sociedad colombiana ha decidido poner fin al conflicto armado interno mediante una solución política y negociada, ha aceptado la reincorporación al pacto social de los insurgentes y se hace imprescindible poner en marcha mecanismos de transición. Dichos instrumentos deben recordar que tradicionalmente se ha dado un trato privilegiado a los responsables de delitos políticos (rebelión, sedición, asonada y los delitos conexos), que a los insurgentes se les ha concedido amnistías e indultos y que la participación en política en condiciones de igualdad es un punto de partida aceptable para la construcción de una paz estable y duradera (Corte Constitucional, Sentencia C-456, 1997).

Por ello, la jurisprudencia del Tribunal Constitucional enseña que el concepto normativo sobre delito político ha sido empleado con tres fines plenamente diferenciables: (i) Permitir que a los condenados por estas conductas les sea otorgada una amnistía o les sea concedido un indulto. Ejemplo de ello, es la consagración que desde 1991 se hizo en el Numeral 17 del Artículo 150 de la Constitución ${ }^{36}$; (ii) impedir que los perseguidos por conductas que se consideren delito

\footnotetext{
${ }^{36}$ ARTICULO 150. Corresponde al Congreso hacer las leyes. Por medio de ellas ejerce las siguientes funciones:
} 
político sean extraditados, tal y como lo prevé el tercer inciso del Artículo $35^{37}$ de la Constitución; (iii) permitir que los condenados por estas conductas participen en política, específicamente para que puedan acceder a cargos públicos y ejercer el derecho de sufragio pasivo. Caso de las previsiones de los Artículos 179 Numeral $1^{\circ}$, respecto de quienes aspiran a ser elegidos como congresistas, 197 inciso segundo, para ser elegido Presidente de la República y Vicepresidente, 232 Numeral $3^{\circ}$, respecto de los magistrados de la Corte Constitucional, la Corte Suprema de Justicia y el Consejo de Estado, y 299 inciso tercero, en relación con los diputados de las asambleas departamentales, todas ellas mencionadas con anterioridad (Ambos \& Steiner, 2015).

Sigue diciendo la Corte Constitucional:

Al tener en cuenta esta diferenciación, resulta evidente que en cuerpos internacionales que forman parte del bloque de constitucionalidad $y$ en diversas sentencias que conforman la jurisprudencia constitucional relativa a la materia, se consagran límites respecto de i) la concesión de amnistías e indultos, así como de ii) la prohibición de extradición de delincuentes por parte del Estado colombiano; límites que a su vez determinan cuáles delitos podrán considerarse como políticos o conexos a delitos políticos cuando estas categorías sean utilizadas con dichos fines.

Limitación de la libertad de configuración normativa del Estado que resulta acorde con el deber de perseguir y sancionar las graves vulneraciones de los Derechos Humanos, por

(...) 17. Conceder, por mayoría de los dos tercios de los votos de los miembros de una y otra Cámara y por graves motivos de conveniencia pública, amnistías o indultos generales por delitos políticos. En caso de que los favorecidos fueren eximidos de la responsabilidad civil respecto de particulares, el Estado quedará obligado a las indemnizaciones a que hubiere lugar.

37 ARTICULO 35. Modificado por el art. 1, Acto Legislativo No. 01 de 1997, el nuevo texto es el siguiente: La extradición se podrá solicitar, conceder u ofrecer de acuerdo con los tratados públicos y, en su defecto, con la ley.

Además, la extradición de los colombianos por nacimiento se concederá por delitos cometidos en el exterior, considerados como tales en la legislación penal colombiana. La Ley reglamentará la materia. La extradición no procederá por delitos políticos. No procederá la extradición cuando se trate de hechos cometidos con anterioridad a la promulgación de la presente norma. 
cuanto la concesión de una amnistía o un indulto, o la prohibición de extradición evitarían que se realizara el componente de justicia al que tienen derecho las víctimas de dichos delitos. Por esta razón, verbigracia, se ha concluido que no es posible reconocer como delitos políticos para estos efectos los delitos atroces o inhumanos, homicidios cometidos fuera de combate, homicidio u otro delito violento contra la persona del Jefe de Estado o de miembros de su familia y genocidio, entre otros ${ }^{38}$ (Sentencia C-577 de 2014, 2014).

Entonces, si tenemos de presente el Artículo 66 (transitorio) de la Constitución Política y la Sentencia C-577 de 2014, se puede advertir que el Estado colombiano puede definir lo que considera como delito político y los conexos con ellos, dependiendo de su sistema político y del momento histórico, para así ampliar y fortalecer tanto la democracia como la participación política en aras de lograr la reconciliación tras la consecución de un acuerdo de paz.

\subsection{Fines de las sanciones o penas en la justicia transicional}

La jurisprudencia explica que el derecho penal en un proceso de justicia transicional exige la prevalencia de las funciones preventivas de la pena y cumple con objetivos específicos plenamente articulados con la reconciliación de la sociedad y la protección de los derechos de las víctimas. Específicamente ha resaltado (C-579 de 2013, 2013):

(i) La prevención general negativa ${ }^{39}$ en un proceso de justicia transicional es fundamental, pues de la seriedad de los mecanismos y de la efectiva condena de los máximos

\footnotetext{
38 Sentencias C-127/93; C-171/93; C-214/93; C-069/94; C-009/95; C-456/97; C-695/02; C-1055/03; C-037/04; C-780/04; C-537/08; y C-011/10, entre otras.

39 "La función del derecho penal en una sociedad secularizada y en el Estado de derecho pretende proteger, con un control social coactivo, ciertos bienes jurídicos fundamentales y determinadas condiciones básicas de funcionamiento de lo social. Por ello se concluye que, tal y como esta Corte lo ha señalado en diversas ocasiones, la definición legislativa de las penas en un Estado de derecho no está orientada por fines retributivos rígidos sino por objetivos de prevención general, esto es, debe tener efectos disuasivos, ya que la ley penal pretende "que los asociados se abstengan de realizar el comportamiento delictivo so pena de incurrir en la imposición de sanciones". Sobre la prevención general de la pena Vid.: Roxin, Claus: Derecho penal. Parte general. Civitas, Madrid, 1997, 89. Jescheck, Hans - Heinrich: Tratado de Derecho penal. Parte general, Comares, Granada, 2002; Muñoz Conde, Francisco / García Arán, Mercedes: Derecho Penal. Parte General, Tirant lo Banch, Valencia, 2007, 48, Feijoo Sánchez, Bernardo: Retribución y prevención general, B de F, Buenos Aires, 2006, 26.
} 
responsables de los delitos de lesa humanidad, genocidio y crímenes de guerra cometidos de manera sistemática, depende de que no exista una repetición de las conductas por parte de otros grupos armados o una reincidencia de los mismos autores de los crímenes (Corte Constitucional, Sentencia C-144, 1997).

(ii) La prevención especial negativa ${ }^{40}$ está directamente relacionada con una de las finalidades esenciales de la justicia transicional: la garantía de no repetición de los crímenes, pues uno de los objetivos esenciales del proceso es prevenir que se sigan cometiendo delitos contra la población. En este aspecto es fundamental que el proceso garantice una real desarticulación de los grupos al margen de la ley y de sus actividades ilícitas, pues de lo contrario continuarán cometiendo crímenes masivos contra la población o se transformarán en otros nuevos con distinto nombre pero con similares objetivos (Roxin, 1997).

(iii) La prevención especial positiva ${ }^{41}$ se realiza mediante una resocialización que se logra con la reintegración seria de los actores armados, la cual solamente se podrá consolidar si se garantiza la participación de los actores en la sociedad (Corte Constitucional, Sentencia C-806, 2002).

(iv) La prevención general positiva ${ }^{42}$ se consigue con el restablecimiento de la confianza de los individuos en el ordenamiento jurídico a través del fortalecimiento del Estado Social de Derecho, de la democracia y del desmantelamiento de organizaciones criminales (Corte Constitucional, Sentencia C-806, 2002).

\footnotetext{
40 La prevención especial negativa señala que la pena puede tener también como misión impedir que el delincuente cometa nuevos crímenes contra la sociedad (vid. Liszt, Franz: Tratado de Derecho penal, T II, Reus, Madrid, 10; Roxin, Claus: Derecho penal. Parte general. Civitas, Madrid, 1997, 85; Jescheck, Hans Heinrich: Tratado de Derecho penal. Parte general, Comares, Granada, 2002, 5; Mir Puig, Santiago: Derecho Penal. Parte General. Reppertor, 2011, 84; Muñoz Conde, Francisco / García Arán, Mercedes: Derecho Penal. Parte General, Tirant lo Banch, Valencia, 2007, 48).

${ }^{41}$ La prevención especial positiva o resocialización señala que la función de la pena es la reintegración del individuo a la sociedad.

42 Para la prevención general positiva la finalidad de la pena es el reconocimiento de la norma con el objeto de restablecer la vigencia de la misma afectada por el delito con el objeto de mantener las estructuras necesarias de una sociedad.
} 
La justicia transicional tiene el gran reto de asegurar al mismo tiempo la paz y la justicia ${ }^{43}$. En este sentido, si bien la amnistía y el indulto se pueden convertir en un medio para facilitar la paz y la reconciliación, no puede transformarse en un instrumento para asegurar intereses personales de inmunidad de la justicia ${ }^{44}$ (Corte Constitucional, Sentencia C-579, 2013).

En tal sentido, la Corte, al hacer referencia al derecho a la justicia, ha establecido las siguientes reglas:

(i) la obligación del Estado de luchar contra la impunidad, (ii) la obligación de establecer mecanismos de acceso ágil, oportuno, pronto y eficaz a la justicia para la protección judicial efectiva de los derechos de las víctimas de delitos. En este sentido, se fija la obligación del Estado de diseñar y garantizar recursos judiciales efectivos para que las personas afectadas puedan ser oídas, y de impulsar las investigaciones y hacer valer los intereses de las víctimas en el juicio, (iii) el deber constitucional de velar porque los mecanismos judiciales internos tanto de justicia ordinaria, como de procesos de transición hacia la paz, tales como amnistías e indultos, no conduzcan a la impunidad y al ocultamiento de la verdad (Corte Constitucional, Sentencia SU-254, 2013).

En este sentido, la propia aplicación del derecho penal en los procesos de justicia transicional tiene características especiales que pueden implicar un tratamiento punitivo más benigno que el ordinario, ya sea mediante la imposición de penas comparativamente más bajas o la adopción de medidas que, sin eximir al reo de su responsabilidad penal y civil, hacen posible

\footnotetext{
${ }^{43}$ Teitel, Ruti: Trasitional Justice, Oxford University Press, Nueva York, 2000, 51.
}

${ }^{44}$ Teitel, Ruti: Trasitional Justice, Oxford University Press, Nueva York, 2000, 53. 
su libertad condicional o, al menos, el más rápido descuento de las penas impuestas como lo dispone efectivamente el Acuerdo Final para la $\mathrm{Paz}^{45}$ (Corte Constitucional, Sentencia T-771, 2011).

También ha considerado esa corporación que el deber de juzgar y condenar a penas adecuadas y proporcionales a los responsables de los crímenes cometidos en el marco del conflicto armado sólo puede tener excepciones en procesos de justicia transicional, en procura de la protección de los derechos mínimos de las víctimas a la Verdad, Justicia, Reparación y No Repetición, sin tener en cuenta de dicho eximente a los responsables de graves violaciones a los Derechos Humanos y al Derecho Internacional Humanitario (Corte Constitucional, Sentencia C-715, 2012).

La teoría del delito cumple con el propósito de organizar y sistematizar los conceptos y criterios fundamentales que explican la función del derecho penal; pero, las categorías y el alcance de las mismas en el derecho penal ordinario tienen que ser reformuladas de cara a la justicia transicional que guiará el proceder de la Jurisdicción Especial para la Paz ${ }^{46}$ (Cote Blanco, 2016, págs. 59-62). Se hace, entonces, necesario elevar la paz a criterio hermenéutico esencial de las categorías del derecho penal transicional, de manera que los conceptos tradicionales de tipicidad, antijuridicidad y culpabilidad tienen que verse permeados con el derecho, deber y valor fundante a la paz.

\footnotetext{
45 Sentencia de la Corte Constitucional C-771/11: "Examinado el concepto, debe señalarse que existen instituciones usuales en la justicia transicional, la mayoría de las cuales suelen adoptarse oficialmente por los Estados mediante la aprobación de leyes o la expedición de normas jurídicas de otro tipo, incluso en algunos casos, reformas constitucionales. Dentro de tales herramientas deben destacarse todas aquellas normas de carácter penal, tanto sustanciales como procesales, que implican un tratamiento punitivo más benigno que el ordinario, sea mediante la imposición de penas comparativamente más bajas, la adopción de medidas que sin eximir al reo de su responsabilidad penal y civil, hacen posible su libertad condicional, o al menos el más rápido descuento de las penas impuestas".

${ }^{46}$ Esto se hace evidente cuando aceptamos que «la dogmática penal en Colombia es producto de un "trasplante" de las categorías y conceptos del derecho penal alemán, el cual implicó un cambio paulatino, en el que poco a poco se dejó de "mirar" hacia otros lugares, sobre todo a Italia... La ciencia jurídico penal en Colombia está en mora de realizar un ejercicio de auto reflexión, en el que el enfoque dogmático deje de ser el enfoque dominante». Cfr. GUSTAVo EMILIO COTE BLANCO, «Comentario», en El futuro de la ciencia jurídico penal alemana, ob. cit., p. 59-60 y 62.
} 
Así mismo, los fines de las penas que se impongan por los jueces de la jurisdicción especial para la paz deben permitir que las víctimas sean reparadas y, de este modo, que la sociedad logre disfrutar del derecho a la paz. Por ello, los criterios orientadores de las penas en el sistema ordinario no son de recibo en la justicia transicional.

Es previsible el surgimiento de conflictos creados por los responsables de los delitos comunes por cuanto se seguirán condenado a penas establecidas en el Código Penal; pero a los miembros de los grupos insurgentes y agentes estatales se les impondrá sanciones bajas o alternativas. Ello se justifica en los estándares que gobiernan la justicia transicional: la búsqueda de la paz, hecho diferente a las connotaciones que rigen los asuntos que competen a la justicia ordinaria.

A lo expuesto hay que sumarle que la justicia ordinaria se aplica para mantener el statu quo. En tanto que la justicia transicional es de carácter fundacional y busca restablecer la paz en una sociedad en conflicto, es la justicia que permite reorganizar el entramado social, acción que debe ser complementada con una vigorosa transformación que posibilite la reinserción plena de un importante grupo disidente; todo a partir del reconocimiento institucional de la existencia de importantes factores que contribuyen a la desigualdad, que necesariamente deben ser removidos para edificar una sociedad más justa en convivencia pacífica, como uno de los fines del estado de derecho ${ }^{47}$.

\footnotetext{
47 Constitución Política de 1991, Artículo 2. Son fines esenciales del Estado: servir a la comunidad, promover la prosperidad general y garantizar la efectividad de los principios, derechos y deberes consagrados en la Constitución; facilitar la participación de todos en las decisiones que los afectan y en la vida económica, política, administrativa y cultural de la Nación; defender la independencia nacional, mantener la integridad territorial y asegurar la convivencia pacífica y la vigencia de un orden justo. Las autoridades de la República están instituidas para proteger a todas las personas residentes en Colombia, en su vida, honra, bienes, creencias, y demás derechos y libertades, y para asegurar el cumplimiento de los deberes sociales del Estado y de los particulares.
} 
En fin, con la aplicación excepcional de la justicia transicional no es posible acudir a los fines y funciones de la pena de la justicia ordinaria, debido a que simplemente derivarían en la imposibilidad de llegar a pactos que permitan la terminación del conflicto, porque la pena no tiene poder disuasorio para los insurgentes.

\section{DE LA RESPONSABILIDAD Y LAS SANCIONES EN LA JURISDICCIÓN ESPECIAL PARA LA PAZ}

\subsection{Responsables ante la Jurisdicción Especial para la Paz}

Según el Acuerdo Final, para que proceda la imposición de una sanción a un comandante de la guerrilla (FRAC-EP) o militar, cuando se trate de la responsabilidad de agentes estatales por responsabilidad de mando, es necesario proceder a la identificación individual del máximo responsable y de los agentes ejecutores de la acción (Gobierno Nacional-FARC-EP, 2016, p. 140). Igualmente, habrá responsabilidad por los actos de los subordinados cuando haya existido un control efectivo de la conducta o el hecho, cuando el miembro que sostiene el mando ha tenido la información del acto antes, durante y después de cometer la conducta enjuiciable y, de haber tenido los medios para evitarlo, no lo evitara (Gobierno Nacional-FARC-EP, 2016, p. 146).

El denominado blindaje jurídico de los Acuerdos de La Habana pasa por precisar y definir el cumplimiento de unos requisitos para llegar hasta la fijación de responsabilidad a los mandos o comandantes a quienes se les atribuirá responsabilidad ante la JEP. La motivación y fundamentación de las decisiones judiciales debe contener: un estudio sobre la existencia de un control efectivo de los comandantes militares sobre los subordinados; el conocimiento del alto mando basado en la información a su disposición antes, durante y después de la realización de la 
respectiva conducta; la existencia de los medios a su alcance para prevenir el acto, y la relevancia de las decisiones tomadas por el respectivo comandante (Gobierno Nacional-FARCEP, 2016, págs. 132, 137 y 146).

\subsection{Sanciones en la Jurisdicción Especial para la Paz: Sanciones significativas, alternativas y sustitutivas}

Cabe resaltar, previo al inicio de este título de sanciones, que en el Acuerdo Final para la Paz no se establecen penas sino sanciones, por lo que luego de que exista una decisión por parte de la JEP lo que se impondrá serán sanciones que variarán de acuerdo a lo establecido en alternativas, propias y ordinarias, de manera que es preciso en primer lugar explicar de qué se tratan y luego continuar a explicar lo que dice el Acuerdo.

En primer lugar, se resalta la discrecionalidad del Estado para establecer las sanciones que aplicará a los máximos responsables; solo está condicionada a que deben ser significativas y, como dicho concepto es abierto, resulta razonable afirmar que "debemos discutir cómo la pena puede funcionar en Colombia como un instrumento útil para conseguir la reconciliación del pais”" (Alvarado Reyes, 2014).

En todo caso, en términos de la Corte Constitucional, "la suspensión total de ejecución de la pena, no puede operar para los condenados como máximos responsables de los delitos de lesa humanidad, genocidio y crímenes de guerra cometidos de manera sistemática” (Corte Constitucional, C-579, 2013), de tal forma que se debe garantizar la verdad sobre las graves violaciones a los Derechos Humanos y al Derecho Internacional Humanitario, a través de mecanismos judiciales o extrajudiciales como la Comisión de la Verdad. 
Empero, la primera fórmula de la justicia transicional es acudir a penas alternativas y sustitutivas, u otras formas de sanción diferentes a las ordinarias, porque no es válido ni legítimo creer que la pena de prisión cumplirá un papel estelar, teniendo en cuenta que con ella se introduciría una barrera que haría imposible cualquier acuerdo de paz.

En foro del Centro Internacional para la Justicia Transicional se reconoció que las penas alternativas no significan ausencia de sanción, las víctimas no tienen un derecho a imponer el castigo aplicable a los victimarios, y las penas reparadoras son una sanción alternativa a la cárcel (Centro Internacional para la Justicia Transicional, 2014).

Si bien la Corte Constitucional tiene definido que resulta inadmisible "la exoneración de los responsables de graves violaciones a los Derechos Humanos y al Derecho Internacional Humanitario y, por tanto, el deber de juzgar y condenar a penas adecuadas y proporcionales a los responsables de los crímenes investigados" (Corte Constitucional, C-715, 2012), esta regla se altera en procesos de justicia transicional en los cuales se investigan las violaciones de Derechos Humanos, donde su finalidad es el restablecimiento de los derechos de las víctimas (Corte Constitucional, C-715, 2012).

\subsection{Descripción de las sanciones previstas en el Acuerdo Final para la Paz}

El Acuerdo sobre víctimas contribuyó a la creación de la JEP que ejerce funciones judiciales y hace parte del Sistema Integral de Verdad, Justicia, Reparación y No Repetición (SIVJRNR); punto 5 del Acuerdo. La JEP cumple con el deber del Estado colombiano de investigar, esclarecer, juzgar y sancionar las graves violaciones a los Derechos Humanos y las graves infracciones al Derecho Internacional Humanitario (DIH) que tuvieron lugar en el 
contexto y en razón del conflicto armado y como tal todas las conductas reprochables de los actores principales del conflicto armado (Gobierno Nacional-FARC-EP, 2016).

En el Acuerdo se hace referencia a las consecuencias jurídicas más allá de las tradicionales, a través de las sanciones dispuestas, limitándolas y restringiéndolas en función de garantizar el derecho a la verdad de las víctimas y la construcción de la paz. Las sentencias del Tribunal para la Paz deben enunciar de manera precisa el contenido de la sanción y lugar de ejecución de la misma, así como las condiciones y efectos de estas, según la tipología determinadas en el Acuerdo, que se resumen en lo siguiente:

(i) Sanciones propias: Se imponen a quienes reconozcan verdad y responsabilidad ante la Sala de Reconocimiento de Verdad y Reparación; tienen una función restaurativa y reparadora del daño causado y, respecto a determinadas infracciones muy graves, tienen un mínimo de duración de 5 años y un máximo de 8 años; comprenden restricciones efectivas de libertades y derechos, tales como la libertad de residencia y movimiento; y, para quienes no hayan tenido una participación determinante en los casos más graves y representativos, la sanción es de 2 a 5 años.

Deben existir los mecanismos idóneos de monitoreo y supervisión para garantizar el cumplimiento de buena fe de las restricciones ordenadas por el Tribunal, para poder certificar su cumplimiento. La JEP determinará las condiciones de restricción efectiva de libertad que sean necesarias para asegurar el cumplimiento de la sanción.

(ii) Sanciones alternativas: Se imponen a quienes reconozcan verdad y responsabilidad ante la Sección de Primera Instancia, antes de proferir la sentencia; tienen una función esencialmente retributiva y la sanción consiste en privación de la libertad de 5 a 8 años; y, para 
quienes no hayan tenido una participación determinante en los casos más graves y representativos, la sanción es de 2 a 5 años.

(iii) Sanciones ordinarias: Se imponen a quienes no hayan reconocido responsabilidad y sean condenados por parte del Tribunal, quienes deben cumplir las funciones previstas en las normas penales. Sin embargo, se restringe la privación efectiva de libertad, la cual no es inferior a 15 años ni superior a 20 años en el caso de conductas muy graves.

Las sanciones son ejecutadas bajo el monitoreo propio del sistema, de un régimen de seguridad y vigilancia; y, se crea un órgano nacional o internacional que debe verificar el cumplimiento de las sanciones.

\subsection{Fines y funciones de las sanciones previstas en el Acuerdo Final para la Paz}

Prescribe el Acuerdo que el fin general de las sanciones es satisfacer los derechos de las víctimas y consolidar la paz, lo que significa que, cualquiera que sea finalmente la pena que se imponga al judicialmente declarado responsable, deberá tener en cuenta los criterios orientadores de Verdad, Justicia, Reparación y garantía de No Repetición como condición para la garantía de seguridad jurídica a los victimarios (Gobierno Nacional-FARC-EP, 2016).

Por otra parte, explícitamente se establecen las funciones de las sanciones propias, que serán restaurativas y reparadoras del daño causado, de tal forma que están ligadas a la satisfacción de los derechos de las víctimas, razón por la que no implican llevar o mantener en recinto carcelario al condenado, aunque sí estará sometido a restricciones de la libertad y de otros derechos (Gobierno Nacional-FARC-EP, 2016). 
Como el marco de justicia del Acuerdo Final está enfocado en la reparación de las víctimas del conflicto armado, puede señalarse lo considerado sobre la justicia restaurativa, según lo explica la Corte Constitucional (C-579 de 2013, 2013):

La justicia restaurativa o por algunos llamada reparadora, contempla numerosas y diversas formas: reparaciones, daños remedios, indemnizaciones, restituciones, compensaciones, rehabilitaciones o tributos. En este sentido, existe un consenso internacional en que: 1) el Estado está obligado a dar una compensación a las víctimas de graves violaciones de Derechos Humanos perpetrados por el Estado; 2) si el gobierno que incurrió en las vulneraciones no compensa el nuevo gobierno está obligado a realizarlas.

En todo caso, la reparación también tiene un ingrediente colectivo, pues en los casos de graves y masivas violaciones a los Derechos Humanos, la sociedad en su conjunto sufre perjuicios (spill over effects) frente a los cuales se deben adoptar medidas. Los programas de reparación a las víctimas por los perjuicios sufridos pueden complementar eficaz y rápidamente las contribuciones de los tribunales y las comisiones de la verdad, ofreciendo indemnizaciones, fomentando la reconciliación y restableciendo la confianza de las víctimas en el Estado.

La reparación no siempre es monetaria, sino que puede consistir en la restitución de los derechos de las víctimas, programas de rehabilitación y medidas simbólicas, como disculpas oficiales, monumentos y ceremonias conmemorativas. (i) En el plano individual, los Principios de Joinet señalan que la reparación a las víctimas puede estar compuesta por las siguientes medidas “a) Medidas de restitución (tendentes a que la víctima pueda volver a la situación anterior a la violación); b) Medidas de indemnización 
(perjuicio síquico y moral, así como pérdida de una oportunidad, daños materiales, atentados a la reputación y gastos de asistencia jurídica); y c) Medidas de readaptación (atención médica que comprenda la atención psicológica y psiquiátrica)". (ii) En el plano colectivo, los Principios de Joinet reconocen la importancia de las medidas de carácter simbólico, a título de reparación moral, tales como el reconocimiento público por parte del Estado de su responsabilidad, las declaraciones oficiales restableciendo a las víctimas su dignidad, las ceremonias conmemorativas, las denominaciones de vías públicas, los monumentos que permiten asumir mejor el deber de la memoria. Sobre el derecho a la reparación, la oficina del Alto Comisionado de las Naciones Unidas para los Derechos Humanos emitió los llamados "Principios y Directrices Básicos sobre el Derecho de las Víctimas de Violaciones Manifiestas de las Normas Internacionales de Derechos Humanos y de Violaciones Graves del Derecho Internacional Humanitario a Interponer Recursos y Obtener Reparaciones" señala que las víctimas tienen derecho a una "reparación adecuada, efectiva y rápida tiene por finalidad promover la justicia, remediando las violaciones manifiestas de las normas internacionales de Derechos Humanos o las violaciones graves del Derecho Internacional Humanitario".

En ese sentido, se entiende que la función de las sanciones alternativas es especialmente retributiva, que en los términos tradicionales se manifiesta en el momento de imposición de la pena, sin perjuicio de que sean inadmisibles los fines retributivos rígidos, ya que debe haber una cierta proporcionalidad entre la pena, el delito y el grado de culpabilidad (Corte Constitucional, Sentencia C-144, 1997).

En conclusión, las funciones de las sanciones alternativas y todas aquellas derivadas y diferentes a las ordinaras están enfocadas a la reparación de las víctimas para garantizar sus 
derechos; y, las funciones de las sanciones ordinarias, serán para quienes no reconozcan responsabilidad ante el Tribunal Especial para la Paz, los cuales son sancionados en los términos del Código Penal con algunos limitantes y las penas cumplirán las funciones previstas en dicho estatuto.

Seguido a todo, se continuará la investigación con las conclusiones propias derivadas del enfoque que le otorga la justicia transicional a la amnistía y el indulto y las justificaciones que otorga el derecho a la verdad y la paz para su otorgamiento.

\section{CAPÍTULO CUARTO}

\section{DERECHO A LA VERDAD COMO JUSTIFICACIÓN DE AMNISTÍAS E INDULTOS: ¿IMPUNIDAD O JUSTICIA?}

\section{La JUSTiCia transicional APLiCABle al CASO COLOMBIANO COMO MEDIDA DE JUSTA PROPORCIÓN PARA LOGRAR LOS FINES DEL ESTADO}

Para desarrollar este capítulo, en el que se responden los interrogante de la investigación, (i) iniciaremos excluyendo el indulto de las prerrogativas otorgadas a los victimarios, ya que se evidenció una falencia en la reglamentación y aplicación de dicha institución; (ii) luego, abordaremos las razones o argumentos por los cuales el derecho a la verdad justifica el otorgamiento de amnistía e indultos en el marco de la justicia transicional; (iii) posteriormente, relacionaremos las condiciones que tiene el otorgamiento de la amnistía; (iv) seguido a lo anterior, realizaremos un test de razonabilidad, conforme a los principios que establece la Corte Constitucional, para encontrar que la medida de cesar la persecución penal es adecuada, 
necesaria y proporcional; y, (v) finalmente, reviviremos algunos apartes del capítulo de justicia para indagar sobre las posibles teorías de la justicia aplicadas en la justicia transicional.

\subsection{Precisión inicial sobre el indulto}

De suma importancia se vuelve resaltar que, si bien se encuentra enunciado el indulto como institución jurídica dispuesta en el Acuerdo Final para la Paz, ni en la Ley 1820 de 2016, ni en otras normas dispuestas para tal fin, se define su carácter, su finalidad, el procedimiento para su otorgamiento, se hace mención alguna en las normas expedidas para la aplicación y funcionamiento del esquema de justicia, razón por la cual se concluye que el desarrollo normativo expedido hasta la fecha no hace referencia al otorgamiento de indultos y dicha institución no ha sido utilizada para otorgar beneficios a los victimarios. Sin embargo, como es una institución que cumple funciones similares a las de la amnistía, también será justificada su utilización bajo la garantía del derecho a la verdad.

\subsection{Precisiones sobre la impunidad en el caso concreto}

Como hemos venido desarrollando en el trasfondo del trabajo investigativo, una de las pretensiones es demostrar que la concesión de amnistías e indultos en el marco de la justicia transicional y, especialmente, en el proceso de paz colombiano, son justas siempre y cuando se pretenda proteger los derechos de las víctimas, especialmente el derecho a la verdad.

En ese orden, el concepto a desvirtuar es la impunidad, es decir, necesitamos conocer a que se debe la impunidad en el marco de una justicia transicional para así poder establecer porque no se cumplen los presupuestos para que esta tome vida en el proceso de paz en Colombia. 
Por ello, debe quedar claro que para que exista impunidad debe existir una deficiencia en los criterios de justicia implantados ordinariamente en una sociedad; sin embargo, según los criterios dirigentes de la Corte Constitucional, los cuales son seguidos para llegar al resultado de la investigación, la existencia de impunidad en un proceso de justicia transicional debe contemplar los siguiente elementos: (i) que no se cumpla la obligación del Estado de investigar las violaciones de los derechos humanos; (ii) que coexista una falla en la adopción de medidas, especialmente judiciales, contra los autores de graves conductas; (iii) que exista una falta en el procesamiento, juzgamiento y sanción con penas apropiadas; y, (iv) que no se garantice a las víctimas directas, con mecanismos eficientes y eficaces, la reparación a través del derecho a la verdad y la no repetición (Corte Constitucional, Sentencia C-007, 2018).

En ese orden de las cosas, los subtítulos que seguidamente se van a desplegar van a incluir argumentos que le darán veracidad a la tesis de que las amnistía e indultos otorgadas a los victimarios en el proceso de paz colombiano no constituyen asomo de impunidad.

\subsection{El derecho a la verdad como justificación de amnistías e indultos: razones que los hacen justos y desvirtúan cualquier asomo de impunidad}

De acuerdo con el análisis realizado durante todo el proyecto investigativo, la respuesta a la pregunta formulada ya debe estar resuelta para el lector, debido a que en el transcurso del escrito se han desarrollado ideas preliminares sobre cómo el derecho a la verdad constituye un instrumento que justifica las amnistías e indultos establecidos en el Acuerdo Final para la Paz, sin que ello constituya impunidad, pues en los términos de justica que plantea la transicionalidad de la guerra a la paz en Colombia, es proporcional imponer las sanciones y otorgar las amnistías 
a los victimarios como lo previó el Acuerdo. Lo expresado se demuestra bajo los siguientes criterios:

(i) Las amnistías y los indultos en Colombia son instituciones idóneas para conseguir la reconciliación nacional y terminar el conflicto armado interno, porque su otorgamiento es el incentivo a los victimarios para garantizar el derechos de las víctimas a las verdad, teniendo en cuenta la premisa que estatuye el Acuerdo Final para la Paz y las leyes que lo desarrollan, en las que, dependiendo del aporte de verdad sobre los hechos que constituyeron el conflicto armado, serán otorgadas las amnistías, de tal forma que son garantía del otorgamiento de la verdad a las víctimas.

La garantía del derecho a la verdad de las víctimas del conflicto armado colombiano legitima las amnistías e indultos dispuestos para las FARC-EP sin que dichas prerrogativas generen impunidad, teniendo en cuenta que las sanciones que se imponen en los procesos de justicia transicional, tanto en su modalidad como en la cantidad, se justifican con los fines que persiguen: la terminación del conflicto armado interno y el establecimiento de una paz estable y duradera. Por lo tanto, se erigen en una medida proporcional e ideal para garantizar derechos y fines del Estado.

Dicho de otro modo, la amnistía y el indulto tienen la condición de instituciones jurídicas; pero, más allá de ello, constituyen instrumentos de política pública idóneos para propender por la construcción de una sociedad que conozca la verdad de lo ocurrido, en la que sus miembros acepten las reglas básicas de convivencia y se respete la institucionalidad vigente. Razón fundamental para que sus efectos se dirijan frente a los delitos políticos y los conexos, de modo 
que resultaría en contra de las normas nacionales e internaciones que el legislador otorgue similares beneficios a los responsables de los delitos comunes.

(ii) La institución encargada de proteger el elemento de justicia, la Jurisdicción Especial para la Paz, puede revocar la libertad de quienes incumplan alguna de las obligaciones fijadas en el acta formal de compromiso, como lo es la de garantizar el otorgamiento de la verdad en los estrados de la JEP, si los victimarios quieren conservar el alivio penal o ser sujetos a una sanción alternativa.

En otras palabras, si durante la vigencia de la Jurisdicción Especial para la Paz, los beneficiarios de mecanismos de tratamiento penal especial de la presente ley, se rehusaran a cumplir los requerimientos del Tribunal para la Paz para participar en los programas de contribución a la reparación de las víctimas, o a acudir ante la Comisión de Esclarecimiento de la Verdad de la Convivencia y No Repetición, o ante la Unidad de Búsqueda de las Personas Dadas por Desaparecidas, se les revocará el derecho a que se les apliquen los beneficios de la libertad condicional o las sanciones establecidas en la JEP.

(iii) Lo anterior, porque todos los victimarios que queden en libertad en virtud de la Ley de Amnistía quedan a disposición de la Jurisdicción Especial para la Paz y deben comparecer ante la misma para que la Sala de Amnistía e Indulto, la Sala de Verdad y Reconocimiento de Responsabilidad, la Sala de Definición de Situaciones Jurídicas o la Sección de Revisión del Tribunal para la Paz, resuelvan su situación. Esto significa que la liberación no es óbice para la extinción de responsabilidades. 
(iv) Las sanciones propias a imponer por la justicia de transición cumplen los estándares internacionales, convenios y tratados que dan parámetros para su imposición, además de que tienen funciones especialmente restaurativas y reparadoras del daño causado.

(v) La aplicación de los tratamientos penales especiales diferenciados, previstos en el Acto Legislativo 01 de 2017 y en la Ley 1820 de 2016, implican reconocer que tal normatividad se ubica en el marco de la justicia transicional que ha sido admitido por la comunidad internacional, siempre y cuando se garantice que las violaciones a los Derechos Humanos y fundamentales sean investigadas, enjuiciadas y reparadas, y los autores de las mismas contribuyan a identificar la verdad de los delitos cometidos y reciban algún tipo de sanción. Exigencias que se cumplen en los trámites que adelanta la Jurisdicción Especial para la Paz, pues, uno de los principios que fundamenta su creación es el de la satisfacción de los derechos de las víctimas a la Verdad, Justicia, Reparación y No Repetición.

(vi) El Artículo 22 del Acto Legislativo 01 de 2017 le impone a la referida jurisdicción, por ejemplo, en los casos de los agentes del Estado y, particularmente, de los miembros de la fuerza pública: respetar las obligaciones internacionales de investigación, juzgamiento y sanción, lo cual significa que para adoptar sus decisiones no le será suficiente la versión que ofrezca el interesado, sino que estará obligada a verificar la información que este suministre.

(vii) El derecho penal o la justicia ordinaria es incapaz de dar satisfacción a las necesidades de las víctimas, por cuanto tiene como finalidad la prevención general, de modo que no se vuelva a cometer delito, exista retribución justa, reinserción social y protección al 
condenado $^{48}$, como propósito de la lucha contra el crimen o de la persecución penal, lo que indica que dicha justicia está enfocada en una gran proporción al victimario. De modo opuesto, los fines de la pena o sanción en la justicia transicional están enfocados a las víctimas: buscan hacer un seguimiento al trauma que ha vivido, reparar integralmente con el apoyo de los perpetradores y, entre otras cosas, reconstruir la confianza en el Estado, lo que no implica que no existan sanciones que amonesten las graves conductas cometidas.

(viii) La interpretación judicial tiene el reto de dinamizar el derecho para ajustarlo a la connotación excepcional inherente a una justicia de transición. Es un desafío que exige creatividad, donde el derecho, entendido como instrumento de construcción y preservación de la paz, ha de moldear los caminos institucionales que permitan garantizar la satisfacción de las expectativas de reconciliación y una dosis admisible de justicia (Bustos Martínez, 2015, p. 18).

(ix) El Acuerdo de Paz y, en consecuencia, la Jurisdicción Especial para la Paz, están debidamente legitimados y fueron adecuadamente refrendados por el Congreso de la República de Colombia, decisión revalidada por la Corte Constitucional. En consecuencia, las decisiones que se tomen con base en el Acuerdo son legítimas y su contenido constitucional, argumento que hace inferir que los jueces investidos para la aplicación de dicho mandado y las normas que lo desarrollan están atribuidos de amplias facultades para impartir pronta y cumplida justicia.

(x) Es constitucional la refrendación y expedición del Acuerdo y sus normas, en el entendido de que los órganos del Estado han cumplido plenamente con su labor encomendada en la norma; por un lado, el Ejecutivo construyó un Acuerdo con un fin legítimo que es alcanzar la paz; por el otro, el Legislativo realizó la refrendación popular para justificar dicho pacto en torno

\footnotetext{
48 Código Penal colombiano: Artículo $4^{\circ}$. Funciones de la pena. La pena cumplirá las funciones de prevención general, retribución justa, prevención especial, reinserción social y protección al condenado.

La prevención especial y la reinserción social operan en el momento de la ejecución de la pena de prisión.
} 
a la sociedad; y, finalmente, la Corte Constitucional verificó judicialmente la constitucionalidad desde su razonamiento de las decisiones adoptadas, lo que valida el contenido de todo el Acuerdo y, en particular, lo que nos interesa: el otorgamiento de amnistías e indultos a partir del otorgamiento de verdad a las víctimas y a la sociedad en general.

(xi) Con todo, no se evidencia asomo de impunidad con las medidas adoptadas referentes a la concesión de amnistías e indultos porque se cumplen con los criterios de justicia adoptados por la Corte Constitucional: (1) en virtud de las disposiciones del acuerdo y las condiciones para el otorgamiento de dichas medidas, se cumple la obligación del Estado de investigar las violaciones de los derechos humanos; (2) se crea la JEP como medida judicial, contra los autores de graves conductas; (3) se estableció procesamiento, juzgamiento y sanción con penas $\operatorname{apropiadas}^{49}$ a los victimarios; y, (4) se garantizan a través de la JEP, la Comisión para el Esclarecimiento de la verdad y la Unidad de Búsqueda de Personas dadas por Desaparecidas, los mecanismos eficientes y eficaces para la reparación de las víctimas a través del derecho a la verdad y la no repetición.

Además de que no es factible endilgarle impunidad a la concesión de amnistías por los argumentos anteriormente planteados, tampoco es posible por las razones que se seguirán exponiendo desde otros ámbitos del proceso transicional.

\footnotetext{
${ }^{49}$ Destaco que la jurisprudencia de la Corte Constitucional (Sentencia 007 de 2018) no exige una pena proporcional a las conductas cometidas, sino una sanción adecuada que se debe imponer en el marco de los fines del Acuerdo Final.
} 


\subsection{Garantía del derecho a la verdad como condición para las sanciones alternativas, propias y ordinarias}

Después de indagar con suficiencia, se encontró que una de las mayores preocupaciones existentes sobre las sanciones previstas en el Acuerdo Final para la Paz se relaciona con la superación de los estándares internacionales establecidos en dicha materia; empero, no se observa la superación de los estándares internacionales, porque la base del componente de justicia está sometido a los tratados y convenios internacionales; se trata de superar un conflicto armado interno y conseguir la reconciliación nacional, por lo que la proporción de las sanciones está enfocada a la protección de los derechos de las víctimas.

Además, en materia internacional, se destacó en la investigación que existen serios compromisos y obligaciones frente a las víctimas que llevan a concluir que obtendrán verdad, reparación y justicia; componentes que de manera equilibrada permitirán restablecer el tejido social, por lo que las sanciones a imponer no pueden ser aparentes y menos pueden ser calificadas como mecanismos de impunidad.

Por ejemplo, se destaca que las penas a imponer a los sujetos condenados por la Corte Penal Internacional (CPI) son extraordinariamente menores a las que prevé la legislación ordinaria nacional ${ }^{50}$, pues, como lo advierte la Corte Constitucional, en los términos del Artículo 77, Numeral 1, del Estatuto de Roma, la pena de prisión que aplica la CPI se pueden extender hasta un tope de 30 años ${ }^{51}$, precepto del que se deduce que no existe un mínimo de reclusión, sólo un máximo (Corte Constitucional, Sentencia C-578, 2002).

\footnotetext{
${ }^{50}$ Por ejemplo, para los delitos contra la administración de justicia previstos en el Artículo 70 del Estatuto de Roma, prevén las siguientes penas: 3 . En caso de decisión condenatoria, la Corte podrá imponer una pena de reclusión no superior a cinco años o una multa, o ambas penas, de conformidad con las Reglas de Procedimiento y Prueba.

${ }^{51}$ Estatuto de Roma de la Corte Penal Internacional, Parte VII. De las penas:
} 
De esa forma, si las sanción máxima para delitos ordinarios que se puede imponer a responsables de delitos que se juzguen en la JEP es de 20 años y la mínima es de 15 años (Gobierno Nacional-FARC-EP, 2016), quiere decir que la sanción impone un limitante mayor al del Estatuto de Roma, por establecer un mínimo, y su máximo se encuentra dentro del rango medio superior al máximo de la pena que puede imponer la CPI, de acuerdo con el Estatuto de Roma. Observamos que para los casos de delitos que merecen sanciones ordinarias por parte de la JEP el tratamiento puede llegar a ser más severo por cuanto el mínimo es de 15 años; situación que no deja asomo de impunidad en la justicia transicional colombiana.

En el mismo sentido, las sanciones alternativas que se imponen por conductas muy graves se otorgarán solamente a quienes reconozcan verdad y responsabilidad antes de sentencia ante la Sección de Enjuiciamiento. Tendrán una pena de prisión con una función esencialmente retributiva, razón por la que "en ningún caso se aplicarán subrogados penales, beneficios adicionales o rebajas complementarias a la sanción alternativa" (Gobierno Nacional-FARC-EP, 2016, págs. 154-155).

Cuando no exista reconocimiento de la verdad y de responsabilidad, funcionarán las previstas en el Código Penal para la omisión a la contribución de la verdad. Así mismo, los condenados tendrán derechos a los subrogados penales o beneficios adicionales siempre y cuando el destinatario se comprometa a contribuir con su resocialización a través del trabajo,

Artículo 77 Penas aplicables:

1. La Corte podrá, con sujeción a lo dispuesto en el artículo 110, imponer a la persona declarada culpable de uno de los crímenes a que se hace referencia en el artículo 5 del presente Estatuto una de las penas siguientes:

a) La reclusión por un número determinado de años que no exceda de 30 años; o

b) La reclusión a perpetuidad cuando lo justifiquen la extrema gravedad del crimen y las circunstancias personales del condenado.

2. Además de la reclusión, la Corte podrá imponer:

a) Una multa con arreglo a los criterios enunciados en las Reglas de Procedimiento y Prueba;

b) El decomiso del producto, los bienes y los haberes procedentes directa o indirectamente de dicho crimen, sin perjuicio de los derechos de terceros de buena fe. 
capacitación o estudio durante el tiempo que permanezca privado de la libertad, y a promover actividades orientadas a la no repetición del daño causado una vez liberado (Gobierno NacionalFARC-EP, 2016, p. 155).

También es destacable que el Acuerdo hace un intento por cerrar todos los caminos donde pueda existir impunidad, de tal forma que hace mención a una autoridad encargada de vigilar el cumplimiento de las sanciones, la cual debe tener como norte los fines atribuidos a las penas que se impongan en la justicia transicional, como lo son la terminación del conflicto, reconciliación nacional y los derechos de las víctimas.

En el mismo sentido, debe destacarse que con motivo del Acuerdo Final suscrito por el Gobierno y las FARC-EP, el jurista internacional Fatou Bensouda declaró que compartía "la esperanza de que este acuerdo de paz será la base para la construcción de una paz duradera en Colombia" (Bensouda, 2016), por cuanto "el acuerdo de paz reconoce el lugar central de las víctimas en el proceso y sus legítimas aspiraciones de justicia. Estas aspiraciones deben ser atendidas plenamente, a través de medidas que aseguren que los responsables de sus sufrimientos sean genuinamente puestos a disposición de la justicia” (Bensouda, 2016).

\subsection{En busca de la proporcionalidad en la concesión de amnistías e indultos}

En términos de justicia hay que aclarar que el principio que define el concepto de justicia es el de igualdad, según lo desarrollado en este texto y lo preceptuado por la Corte Constitucional colombiana. Esto puede entenderse cuando se realiza el test de razonabilidad, por el cual podemos identificar las respuestas a la existencia de condiciones desiguales de los victimarios con respecto de los delincuentes comunes, sobre las condiciones diferentes del juzgamiento de los delitos cometidos por las FARC-EP y las conductas delictivas usuales. 
La Corte Constitucional ha establecido una regla de ponderación para realizar ese tipo de análisis, con el fin de establecer si las medidas que son adoptadas por el estado pueden llegar a ser razonables, de tal forma que cumplan con dichos requisitos. Al respecto, mencionó esa alta corporación que (Corte Constitucional, Sentencia C-022, 1996):

El test de razonabilidad es una guía metodológica para dar respuesta a la tercera pregunta que debe hacerse en todo problema relacionado con el principio de igualdad: ¿cuál es el criterio relevante para establecer un trato desigual? o, en otras palabras, ¿es razonable la justificación ofrecida para el establecimiento de un trato desigual? (...)

La teoría jurídica alemana, partiendo de la jurisprudencia del Tribunal Constitucional Federal, ha mostrado cómo el concepto de razonabilidad puede ser aplicado satisfactoriamente sólo si se concreta en otro más específico; el de proporcionalidad. El concepto de proporcionalidad sirve como punto de apoyo de la ponderación entre principios constitucionales: cuando dos principios entran en colisión, porque la aplicación de uno implica la reducción del campo de aplicación de otro, corresponde al juez constitucional determinar si esa reducción es proporcionada, a la luz de la importancia del principio afectado. (...)

El concepto de proporcionalidad comprende tres conceptos parciales: la adecuación de los medios escogidos para la consecución del fin perseguido, la necesidad de la utilización de esos medios para el logro del fin (esto es, que no exista otro medio que pueda conducir al fin y que sacrifique en menor medida los principios constitucionales afectados por el uso de esos medios), y la proporcionalidad en sentido estricto entre 
medios y fin; es decir, que el principio satisfecho por el logro de este fin no sacrifique principios constitucionalmente más importantes. (...)

En el caso concreto del principio de igualdad, el concepto de proporcionalidad significa, por tanto, que un trato desigual no vulnera ese principio sólo si se demuestra que es (1) adecuado para el logro de un fin constitucionalmente válido; (2) necesario, es decir, que no existe un medio menos oneroso, en términos del sacrificio de otros principios constitucionales, para alcanzar el fin; y (3) proporcionado, esto es, que el trato desigual no sacrifica valores y principios (dentro de los cuales se encuentra el principio de igualdad) que tengan un mayor peso que el principio que se quiere satisfacer mediante dicho trato.

Entonces, para entender por qué son razonables las medidas adoptadas por el Estado al observar condiciones desiguales entre el juzgamiento de los miembros de las FARC-EP y la delincuencia común, hay que entender igualmente porque son adecuadas, necesarias y proporcionales. Con el fin de ponderar los principios constitucionales que rigen las decisiones adoptadas, debemos tener en cuenta que en la balanza de principios y fines del Estado, para el caso concreto, están la consecución de la paz y la persecución penal de los responsables de graves violaciones a los Derechos Humanos e infracciones al Derecho Internacional Humanitario.

En ese sentido, se puede inferir que las decisiones adoptadas en materia de justicia por el Acuerdo Final para la Paz, sobre todo en lo desarrollado en este texto, son justas de acuerdo con el test planteado por la Corte Constitucional, así: 
(i) Está demostrado que la medida adoptada por el Estado colombiano en materia de justicia (punto 5 del Acuerdo), referente en la concesión de amnistías e indultos a los victimarios que hayan cometido delitos políticos y conexos con ellos, es adecuada porque busca el logro de la paz como fin constitucional válido. Se realiza plenamente el Artículo 22 de la Constitución Nacional que impone a todos, incluyendo a la institucionalidad, el deber de buscar la paz;

(ii) La medida acogida es necesaria porque no existe otra forma para la consecución de la paz y para garantizar los derechos de las víctimas a la Verdad, Justicia, Reparación y No Repetición, sino con la cesación de la persecución penal a través de las instituciones amnistía e indulto, que se convierten en garantía para los derechos de las víctimas, teniendo en cuenta que no se logró acabar con el conflicto a pesar de centenares de intentos hechos durante años. Ello, también, porque toda sociedad civilizada tiene como paradigma la búsqueda de consensos que permitan la convivencia pacífica, dejando de lado una guerra permanente e indefinida, como mecanismo para la solución del conflicto armado interno; y,

(iii) La decisión es proporcional porque, si bien existe un trato desigual a nivel punitivo a favor de las FARC-EP, este se da por: la persecución de la terminación de un conflicto armado que permaneció durante décadas; la búsqueda de la reconstrucción de la confianza de la ciudadanía hacia el Estado colombiano; la restauración del tejido social; el paso a la legalidad del grupo al margen de la ley; la garantía los derechos de las víctimas el reconocimiento del Estado por parte de los ciudadanos que hacían parte de las FARC-EP; el restablecimiento de la justicia; la garantía de la rendición de cuentas sobre los bienes apropiados de manera irregular y la garantía de reconciliación nacional; el cese a los abusos y las graves violaciones a derechos y, sobre todo, la obtención de la verdad de lo ocurrido para la reconstrucción de la historia y la 
memoria social. Todo lo cual, contribuye a ampliar, profundizar y consolidar una sociedad más democrática, al incluir a quienes se habían marginado de la institucionalidad.

\subsection{Nociones de la justicia aplicadas en el proceso de justicia transicional colombiano}

La justicia transicional, en la línea del pensamiento de esta obra y conforme lo resaltan y confirman algunos autores, son los procesos mediante los cuales se busca poner fin a un conflicto existente donde se han producido abusos y graves violaciones a Derechos Humanos, sea por el paso de una dictadura o el retiro de un grupo armado al margen de la ley, a través de mecanismos políticos, judiciales y no judiciales para garantizar la accesibilidad y rendición de cuentas, promover la reconciliación nacional, restablecer la confianza en las instituciones estatales y lograr uno de los fines del estado: la paz (Ríos Martín, 2017).

En Colombia se está viviendo la aplicación de la justicia transicional. Deben mediar suficientes garantías para dar seguridad jurídica a los perpetradores y reconocer los derechos de las víctimas como lo son la Verdad, Justicia, Reparación y No Repetición. Para que ello funcione, debe subdividirse el proceso transicional en un proceso donde exista justicia restaurativa y justicia distributiva.

Lo dicho, por cuanto no es posible en los casos de un posconflicto la aplicación de la justicia ordinaria conforme lo destaca la Corte Constitucional, por la aparente tensión irresoluble que surge entre justicia y paz, que se basa, principalmente, en la asociación de la justicia a la retribución, mediante el castigo penal, lo que deja de lado otras concepciones de justicia (Corte Constitucional, Sentencia C-007, 2018). 
Es decir, la justicia retributiva surge de las normas internas de derecho penal, pero se relaciona también con las obligaciones internacionales en materia de DIDH, DIH y DPI, que permiten el castigo directo a los responsables de las más graves violaciones a los derechos humanos; empero, los deberes de la justicia retributiva son percibidos en ocasiones como un obstáculo para la materialización de paz, debido a que los participantes directos en las hostilidades se rehusarían una negociación que tenga como único resultado un castigo particularmente severo, por lo contrario no se rehusaron ni se rehusarían a una justicia donde el centro de esta sea la garantía de los derechos de las víctimas como lo es la verdad, justicia, reparación y no repetición (Corte Constitucional, Sentencia C-007, 2018).

Por ello, dejando de lado ese mínimo de retribución, el marco de la justicia transicional tiene su fundamento en unas penas menos severas o alternativas, que las del derecho penal ordinario, porque el castigo no puede considerarse un bien o un fin en sí mismo.

Por esas razones, son otros tipos de justicia los que se utilizan para el cumplimiento de los fines de los procesos de justicia transicional y los del Estado. Una de esas concepciones de justicia es la distributiva, la cual se constituye en una justicia ideal, por cuanto se trata de que las desigualdades sociales sean ventajosas para todos, que las grandes instituciones sociales distribuyan los derechos y deberes fundamentales y determinan la división de las ventajas provenientes de la cooperación social (Rawls, 1995, pp. 67-68).

Igualmente, como referente de la justicia transicional esta la justicia restaurativa, la cual tiene como fin último resolver el conflicto enfocándose en la compensación del daño a las víctimas, de tal manera que los delincuentes se hagan responsables de sus acciones (Naciones Unidas Contra la Droga y el Delito, 2006, pp. 5-7). 
Desde esas dos perspectivas obligatorias encontramos que: por un lado, con base en la justicia distributiva, el estado debe cumplir con su finalidad, garantizando la protección de los derechos fundamentales, entre los que se encuentra el derecho a la paz y el derecho a la verdad histórica, aceptando la desigualdad solamente en casos de que sea provechosa para el bien común; es decir, que sea ventajosa para todos; y, por el otro lado, con fundamento en la justicia restaurativa debe evidenciarse la reparación integral a la víctima del conflicto armado, garantizar el derecho a la verad, la reparación economica, el acceso a la justicia y la inclusión de los victimarios al régimen legal estatal para garantizar la no repetición.

En todo caso, para la aplicación de cada una de esas teorías dentro del marco de la justicia transicional colombiana, desde la perspectiva del Acuerdo Final, especialmente debe protegerse el derecho a la verdad porque se siembra como condición indispensable para el otorgamiento de amnistías e indultos, la concesión de sanciones alternativas, la garantía de continuar con el alivio penal y hasta para la misma reconciliación y fin último de la paz, por cuanto son las víctimas directas del conflicto armado quienes deben retomar la confianza en el Estado y contribuir a la reconstrucción del entramado social. 


\section{CONCLUSIONES}

Con todo, en la investigación quedó esclarecido (i) que el derecho a la verdad junto con el derecho a la paz, como fin del Estado, justifican la concesión de amnistías e indultos en Colombia y en otros países; (ii) que la amnistía se constituye en el instrumento idóneo para garantizar el derecho a la verdad de la víctimas por las condiciones de su otorgamiento; (iii) que la amnistía es una institución política mediante la cual se concede el alivio penal más amplio a los victimarios para poder cumplir con uno de los fines del Estado, la paz; (iv) que en términos de la justicia transicional es proporcional conceder amnistías e indultos con el objetivo de la protección de los derechos de las víctimas a la Verdad, Justicia, Reparación y No Repetición; (v) que no es posible la aplicación de la justicia penal ordinaria para la imposición de sanciones a los victimarios porque no sería posible garantizar los derechos de las víctimas y, en ese sentido es desproporcionado en el marco de la terminación del conflicto armado; y, (vi) para la aplicación de los procesos de justicia transicional debe observarse el cumplimiento de los parámetros establecidos en la justicia distributiva y restaurativa, con el fin de reparar las víctimas y garantizar la decisión más ventajosa para concretar las finalidad del estado como lo es la paz. 


\section{REFERENCIAS BIBLIOGRÁFICAS}

Alexy, R. (1997). Teoría de los derechos fundamentales. Madrid: Centro de Estudios Constitucionales.

Alexy, R. (2003). Tres escritos sobre derechos fundamentales y la teoría de los principios. Bogotá D.C., Colombia: Universidad Externado de Colombia.

Alvarado Reyes, Y. (23 de octubre de 2014). Reforma a la Justicia y Justicia Transicional. Ibague.

Ambos, K., \& Steiner, C. (2015). Justicia de transición y constitución II. Analisis de la sentencia C-577 de 2014 de la Corte Constitucional. Bogotá: Temis.

Arango, D. (2 de octubre de 2016). El Tiempo.com. Obtenido de http://www.eltiempo.com/política/proceso-de-paz/gano-el-no-en-el-plebiscito-por-la-paz2016-39626

Asamblea general de las Naciones Unidas. (10 de diciembre de 1948). Declaraciòn Universal de Derechos Humanos. Paris.

Asamblea General de las Naciones Unidas. (12 de noviembre de 1984). resolución 39/11.

Asamblea Nacional Constituyente. (5 de agosto de 1886). Constitución Política de 1886. Bogotá.

Asamblea Nacional Constituyente de 1991. (1991). Constitución Política. Bogotá, Colombia: Leyer.

Atienza, M. (2007). El sentido del Derecho (3 ed.). Barcelona: Ariel.

Auto AP2445-2017, Expediente 49979 (Corte Suprema de Justicia 19 de 4 de 2017).

Auto AP3004-2017, Expediente 49253 (Corte Suprema de Justicia 10 de mayo de 2017).

Auto AP3005-2017, Expediente 49134 (Corte Suprema de Justicia 10 de mayo de 2017). 
Auto AP3393-2017, Expediente 50220 (Corte Suprema de Justicia 31 de mayo de 2017).

Auto AP3947-2017, Expediente 49470 (Corte Suprema de Justicia 21 de junio de 2017).

Auto AP880-2017, Expediente 50802 (Corte Suprema de Justicia 2 de agosto de 2017).

Auto de Segnda Instancia, Radicado 118 (Corte Suprema de Justicia 18 de marzo de 1986).

Auto AP688-2017, Expediente 50301 (Corte Suprema de Justicia 24 de julio de 2017).

Barbosa, F. (2017). Informe de Ponencia para Primer Debate al Proyecto de Acto Legislativo 01 de 2016 Senado. Bogotá: Gaceta del Congreso 52.

Bello, R. (2017). Informe de Ponencia para Primer Debate al Proyecto de Acto Legislativo 01 de 2016 Senado. Congreso de la República. Bogotá: Gaceta del Congreso 52.

Bensouda, F. (24 de agosto de 2016). Corte Penal Internacional. Obtenido de https://www.icccpi.int//Pages/item.aspx?name=160901-otp-stat-colombia\&ln=Spanish

Botero Marino, C., \& Restrepo Saldarriaga, E. (2006). Estandares internacionales y procesos de transición en Colombia. En R. Uprimny Yepes, M. Saffon Sanin, C. Botero Marino, \& E. Restrepo Saldarriaga, ¿Justicia Transicional sin transición? verdad, justicia y reparación para colombia (págs. 53-55). Bogotá: Ediciones Antropos.

Bustos Martínez, J. L. (2015). Justicia transicional, paz y posconflicto. Bogotá: Imprenta Nacional de Colombia.

C-160 de 2017, Expediente RDL-001 (Corte Constitucional 9 de marzo de 2017).

C-179 de 1994, Expediente No. P.E. 002 (Corte Constitucional 13 de abril de 1994).

C-579 de 2013, Expediente D-9499 (Corte Constitucional 28 de 8 de 2013).

C-699 de 2016, Expediente D-11601 (Corte Constitucional 13 de diciembre de 2016).

C-715 de 2012, Expediente D-8973 (Corte Constitucional 13 de Septiembre de 2012). 
Caballero García, F. (2006). La Teoría de la Justicia de John Rawls. Iberóforum. Revista de Ciencias Sociales de la Universidad Iberoamericana, 1-22.

Calderón Rojas, J. (2016). Etapas del Conflicto Armado en Colombia: hacia el posconflicto. Latinoamérica, 62, 227-257.

Cardenas Sierra, C. A. (diciembre de 2017). Analisis del Acuerdo de Paz entre el Gobierno y las Farc desde la filosofía del derecho de Tomás de Aquino. (G. d. Colciencias), Ed.) Colombia.

Caso Bámaca Velásquez Vs. Guatemala, 91 (Corte Interamericana de Derechos Humanos 25 de noviembre de 2000).

Caso Barrios Altos Vs. Perú , 75 (Corte Interamericana de Derechos Humanos 14 de marzo de 2001).

Caso Gomes Lund y otros ("Guerrilha do Araguaia") Vs. Brasil, 11.552 (Corte Interamericana de Derechos Humanos 24 de noviembre de 2010).

Caso Myrna Mack Chang Vs. Guatemala , 101 (Corte Interamericana de Derechos Humanos 25 de noviembre de 2003).

Caso Velásquez Rodríguez Vs. Honduras, 4 (Corte Interamericana de Derechos Humanos 29 de julio de 1988).

Centro Internacional para la justicia trancisional. (2013). En busca de la verdad. Elementos para la creación de una comisión de la verdad eficaz. (E. G. Varney, Ed.) Brasilia: ICTJ.

Cesar, C. (17 de noviembre de 1982). 67 indultos y amnistías ha habido en Colombia. El Tiempo, pág. 6A.

Colegio Revisor Constituyente y Electoral. (1815). Constitución de la Provincia de Antioquia. 1. Imprenta del Gobierno. 
Congreso de Colombia. (26 de diciembre de 1997). Ley 1418 de 1997. Por la cual se consagran unos instrumentos para la búsqueda de la convivencia, la eficacia de la justicia y se dictan otras disposiciones.

Congreso de Colombia. (21 de diciembre de 2010). Ley 1421 de 2010 . Ley de Orden Público. Bogotá.

Congreso de la República de Colombia. (24 de julio de 2000). Ley 599 de 2000. Bogotá: Gaceta del Congreso.

Congreso de la República de Colombia. (25 de julio de 2005). Ley 975. Bogotá: Diario Oficial.

Congreso de la República de Colombia. (30 de noviembre de 2010). Gaceta del Congreso 981. Bogotá.

Congreso de la República de Colombia. (7 de julio de 2016). Acto Legislativo 01 de 2016. Bogotá, Colombia: Gaceta del Congreso.

Congreso de la República de Colombia. (30 de diciembre de 2016). Ley 1820 de 2016. Bogotá: Gaceta del Congreso.

Congreso de la República de Colombia. (11 de mayo de 2017). Acto Legislativo 02 de 2017. Bogotá: Gaceta del Congreso.

Congreso de la República de Colombia. (5 de abril de 2017). Decreto 588 del 2017. Bogotá.

Congreso de la República de Colombia. (15 de marzo de 2018). Decreto 522 de 2018. Bogotá, Colombia: Gaceta del Congreso.

Contreras, S. (2012). La justicia en Aristóteles. Una revisión de las ideias fundamentales de Ethica Nicomachea. Ágora. Estudos Clássicos em Debate, 63-80.

Convención de Ginebra. (1977). Protocolo Adicional I a la Convención de Ginebra de 1949. Protección de las víctimas de los conflictos armados internacionales. Ginebra. 
Cote Blanco, G. E. (2016). Comentarios. En K. Ambos, El futuro de la ciencia jurídico penal alemana (págs. 51-69). Bogotá: Temis.

Durango Álvarez, G. (2011). Justicia, Derecho e igualdad. Forum, 35-64.

Enciclopedia Jurídica Omeba. (1961). Enciclopedia Jurídica Omeba. En Tomo XV (pág. 591). Buenos Aires: Bibliografía Argentina.

Expediente 34959, 34959 (Corte Suprema de Justicia 9 de febrero de 2011).

Fajardo Arturo, L. (2012). Elementos estructurales del derecho a la verdad. Civilizar, 15-34.

Faralli, C. (2007). La filosofía del derecho contemporánea. (S. P. Latorre, Trad.) Bogotá: Universidad Externado de Colombia.

Ferrajoli, L. (1999). Derechos y garantías. Madrid: Trotta.

Fioravanti, M. (1996). Los Derechos Fundamentales-Apuntes de Historia de las Constituciones. (M. M. Neira, Trad.) Madrid, España: Trotta.

Giraldo Forero, J. (diciembre de 2005). COLOMBIA IN ARMED CONFLICT? Papel Politico(18), 43-78.

Gobierno Nacional-FARC-EP. (2016). Acuerdo Final para la Terminación del Conflicto y la Construcción de una Paz Estable y Duradera. Bogotá: Dialogos de la Habana.

Gómez de la Torre, I. b. (2017). La justicia transicional en Brasil. El caso de la guerra de Araguaia. Salamanca: Ediciones Universidad de Salamanca.

Guzmán Campos, G., Fals Borda, O., \& Umaña Luna, E. (2010). La violencia en Colombia. Punto de Lectura.

Habermas, J. (2007). Verdad y justificación. Madrid, España: Trotta.

ICTJ. (20 de Mayo de 2014). Obtenido de https://www.ictj.org/es/news/conversatorio-penasalternativas-sanciones-extrajudiciales-colombia 
Kai Ambos, C. (2008). El Marco Jurídico de la Justicia de Transición. Bogotá, Colombia: Temis.

Leal Buitrago, F. (2006). La política de seguridad democratica. Analisis Político(57), 3-30.

Manzini, V. (1950). Tratado de Derecho Penal. Bogotá: Temis.

Mardones , J., \& Mate, R. (2003). La ética ante las víctimas. Barcelona, España: Anthropos.

Melo, J. (2018). Historia Mínima de Colombia. Madrid: Turner Publicaciones.

Monmsen, T. (1976). Derecho Penal Romano. Bogotá: Temis.

Montalvo Velásquez, C. (2012). Conflicto armado en Colombia: un estudio desde el paradigma neoconstitucional. Pensamiento Americano, 51-75.

Naciones Unidas. (2004). Informe del Secretario General sobre el estado de derecho y la justicia de transición en las sociedades que sufren o han sufrido conflictos. Nueva York: Organización de Naciones Unidas. Obtenido de http://www.un.org/es/comun/docs/?symbol=S/2004/616

Naciones Unidas. (2010). Convención Internacional para la Protección de Todas las Personas Contra la Desaparición Forzada.

Naciones Unidas Contra la Droga y el Delito. (2006). Manual sobre Programas de Justicia restaurativa. Nueva york: NACIONES UNIDAS .

Naqvi, Y. (Junio de 2006). El derecho a la verdad en el derecho internacional ¿realidad o ficción? International Reviw of the Red Cross, 3.

Organización de Estados Americanos. (22 de noviembre de 1969). Convención Americana sobre Derechos Humanos. CONVENCION AMERICANA SOBRE DERECHOS HUMANOS (Pacto de San José). San José, Costa Rica.

Ortegón, G. (2017). Informe de Ponencia para Primer Debate al Proyecto de Acto Legislativo 01 de 2016 Senado. Bogotá: Gaceta del Congreso 52. 
Palacio del Poder Ejecutivo de Santafe. (1811). Constitución de Cundinamarca. 1. Santafe de Bogotá: Imprenta Patriotica.

Ponce de León Armenta, L. (1996). Metodología del Derecho. México: Porrúa.

Poveda Perdomo, A. (1984). Amnistía e indulto. Nuevo Veredicto, 43-51.

Poveda Perdomo, A., \& Poveda Perdomo, A. (2014). Hábeas corpus, vías de hecho y proceso penal. Bogotá: Ibañez.

Poveda Perdomo, A., Poveda Perdomo, A., \& Poveda Rodríguez, A. (2017). Problemas Hermenéuticos de la Ley de Amnistía. Bogotá: Ediciones Nueva Jurídica.

Presidencia de la República. (17 de febrero de 2017). Decretro 277 de 2017. Bogotá.

Ramelli, A. (2017). Informe de Ponencia para Primer Debate al Proyecto de Acto Legislativo 01 de 2016 Senado. Bogotá: Gaceta del Congreso 52.

Rawls, J. (1995). Teoría de la Justicia. México D.F., México: Fondo de Cultura Económica.

Ríos Martín, J. C. (2017). Justicia Restaurativa y transicional en España y Chile. Granada: Comares.

Romeike, S. (2016). La justicia transicional en Alemania después de 1945 y después de 1989. Egidienplatz 23, 1-80.

Roxin, C. (1997). Derecho penal. Parte general. Madrid: Civitas.

Ruiz Monroy, J. (septiembre de 2016). La Verdad en el Derecho. Intersticios Sociales, 1-33.

Santa fe de Bogotá. (12 de junio de 2018). Biblioteca Virtual Miguel de Cervantes. Obtenido de http://www.cervantesvirtual.com/obra-visor/constitucion-de-cundinamarca-30-de-marzode-1811-y-promulgada-el-4-de-abril-de-1811--0/html/

Sentencia, 094 (Corte Suprema de Justicia 12 de julio de 1990).

Sentencia C-022 de 1996, Expediente No. D-1008 (Corte Constitucional 23 de enero de 1996). 
Sentencia C-144 de 1997, Expediente L.A.T.-084 (Corte Constitucional 19 de marzo de 1997).

Sentencia C-225 de 1995, Expediente No. L.A.T.-040 (Corte Constitucional 18 de mayo de 1995).

Sentencia C-379 de 16, Expediente PE-045 (Corte Constitucional 18 de julio de 2016).

Sentencia C-456 de 1997, Expediente No. D-1615 (Corte Constitucional 23 de septiembre de 1997).

Sentencia C-577 de 2014, Expediente D-9819 (Corte Constitucional 6 de agosto de 2014).

Sentencia C-578 de 2002, Expediente LAT-223 (Corte Constitucional 30 de Julio de 2002).

Sentencia C-579 de 2013, Expediente D - 9499 (Corte Constitucional 28 de Agosto de 2013).

Sentencia C-715 de 2012, Expediente D-8963 (Corte Constitucional 13 de septiembre de 2012).

Sentencia C-806 de 2002, Expediente D-3936 (Corte Constitucional 3 de octubre de 2002).

Sentencia SU-254 de 2013, Expedientes T-2.406.014 y acumulados (Corte Constitucional 24 de abril de 2013).

Sentencia C-007 de 2018, Expediente RPZ-001 (Corte Constitucional 1 de marzo de 2018).

Sentencia T 177 de 2011, Expediente T-2.844.031 (Corte Constitucional 14 de marzo de 2011).

Sentencia T-771 de 2011, Expediente D-8475 (Corte Constitucional 13 de octubre de 2011).

Steiner, C., \& Ambos, K. (2008). El Marco Jurídico de la Justicia Transicional. Bogotá: Temis.

Uprimny Yepes, R. (2006). Las enseñansas del analisis comparado: procesos transicionales, formas de justicia transicional y el caso colombiano. En R. Uprimny Yepes, M. Saffon Sanín , C. Botero Marino, \& E. Restrepo Saldarriaga, ¿Justicia transicional sin transición? Verdad, justicia y reparación para Colombia (pág. 19). Bogotá D.C., Colombia: Ediciones Antropos. 
Uprimny Yepes, R., Saffon Sanín, M. P., Botero Marino, C., \& Restrepo Saldarriaga, E. (2006). ¿Justicia transicional sin transición? Verdad, justicia y reparación para Colombia. Bogotá: Antropos.

Uprimny, R. (2017). Informe de Ponencia para Primer Debate al Proyecto de Acto Legislativo 01 de 2016 Senado. Bogotá: Gaceta del Congreso 52.

Uribe Vargas, D. (1977). Las Constituciones de Colombia. Madrid: Cultura Hispanica.

Valdeleón, É. (2017). Informe de Ponencia para Primer Debate al Proyecto de Acto Legislativo 01 de 2016 Senado. Bogotá: Gaceta del Congreso 52.

Villarraga Sarmiento, A. (2015). Los procesos de paz en Colombia, 1982-2014. Bogotá: Fundaciòn Cultura Democratica.

Zafra, G. (2017). Informe de Ponencia para Primer Debate al Proyecto de Acto Legislativo 01 de 2016 Senado. Bogotá: Gaceta del Congreso 52.

Zamora Acevedo, M. (2014). La busqueda de la verdad en el proceso penal. Acta Académica, 147-186.

Zúñiga Urbina, F. (1997). Amnístia ante la jurisprudencia (Derechos Humanos como límite al ejercicio de la soberanía). Revista de Derecho Público, 371-422, 381-382. 